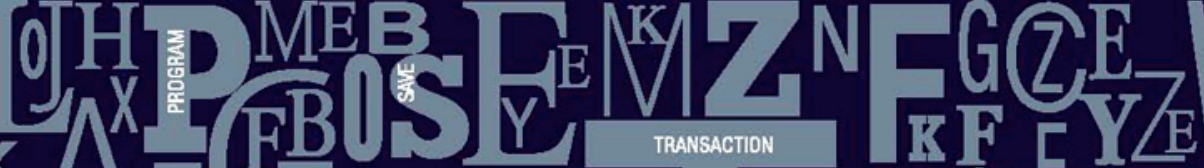

F $\mathrm{Y}$ N R T N (s) $\mathrm{C}$ KNAıM $R$

\title{
GLOSARIO
}

\section{de Preservación Archivística Digital Versión 4.0}

Juan Voutssas M.

Alicia Barnard Amozorrutia

(COORDINADORES)

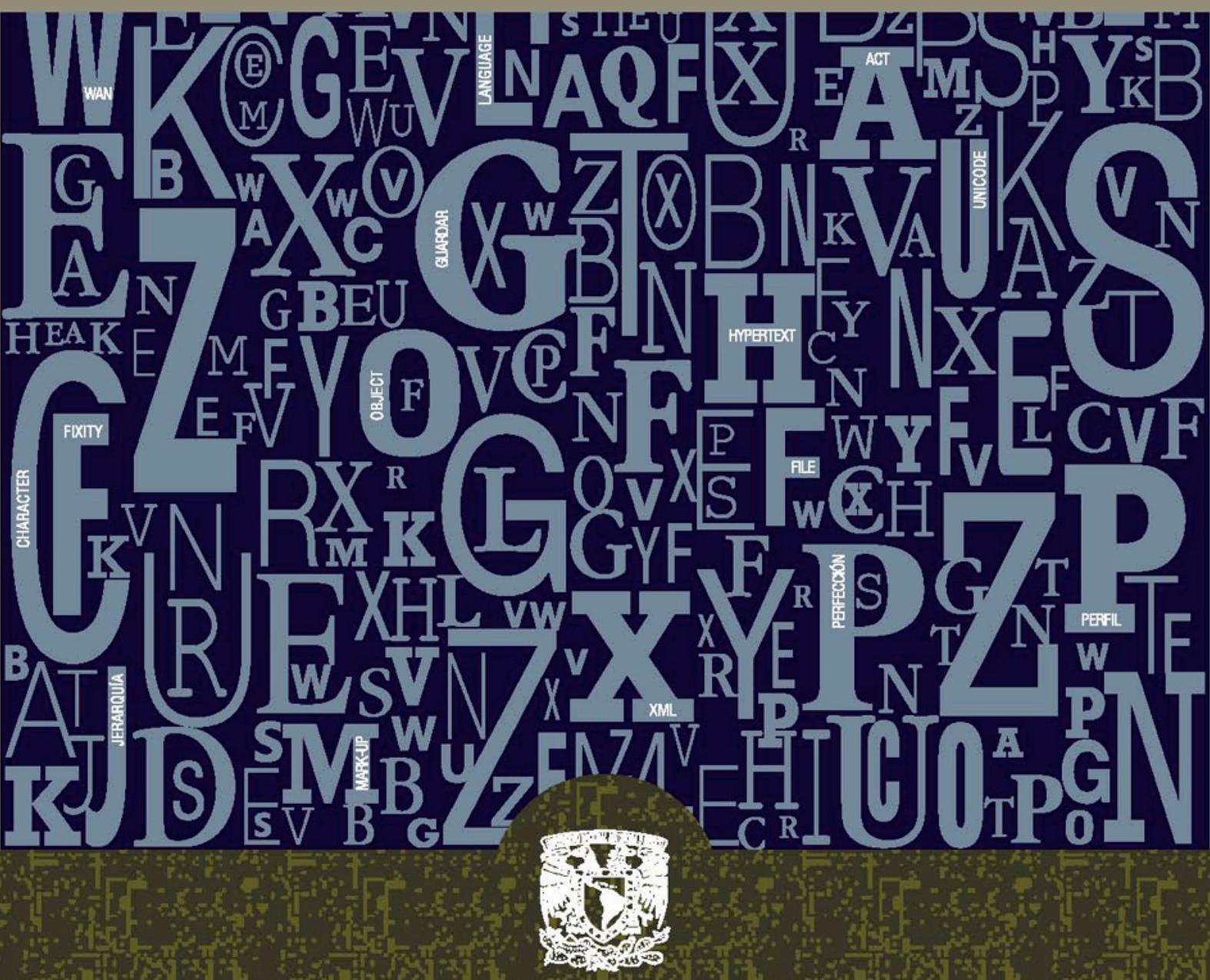




\section{La presente obra está bajo una licencia de:}

\section{http://creativecommons.org/licenses/by-nc-sa/3.0/deed.es MX}

\section{Atribución-No Comercial-Licenciamiento Reciproco 3.0 Unported}

Eres libre de:

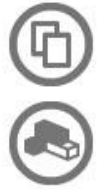

copiar, distribuir y comunicar públicamente la obra

hacer obras derivadas

Bajo las condiciones siguientes:

Atribución - Debes reconocer la autoría de la obra en los términos

especificados por el propio autor o licenciante.

No comercial - No puedes utilizar esta obra para fines comerciales.

Licenciamiento Recíproco - Si alteras, transformas o creas una obra a

partir de esta obra, solo podrás distribuir la obra resultante bajo una licencia

igual a ésta.

\section{Esto es un resumen fácilmente legible del: texto legal (de la licencia completa)}

En los casos que sea usada la presente obra, deben respetarse los términos especificados en esta licencia.
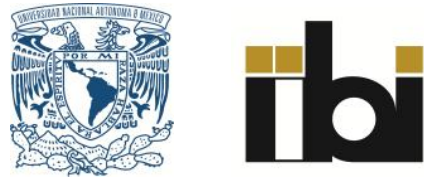
Glosario de Preservación Archivística Digital

Versión 4.0 


\title{
Glosario de Preservación Archivística Digital Versión 4.0
}

\author{
Coordinadores \\ Juan Voutssas-M. \\ Alicia Barnard Amozorrutia
}

Universidad Nacional Autónoma de México 2014 


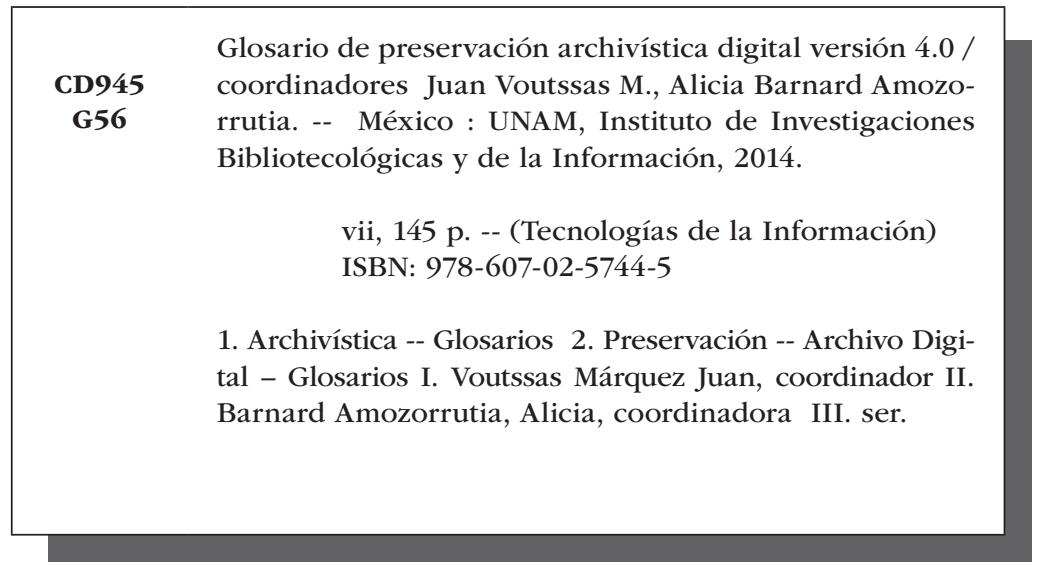

Diseño de portada: Jacobo Iván Martínez Vitela

Primera edición 2014

DR (C) Universidad Nacional Autónoma de México

Ciudad Universitaria, 04510, México D.F.

Impreso y hecho en México

ISBN: 978-607-02-5744-5 


\section{Contenido}

Presentación $\ldots \ldots \ldots \ldots \ldots \ldots \ldots \ldots \ldots \ldots \ldots \ldots \ldots \ldots \ldots \ldots \ldots$

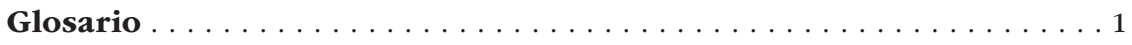

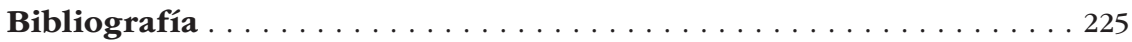

Anexo . . . . . . . . . . . . . . . . . . . . . . . . . . . . . . . . 229 



\section{Presentación}

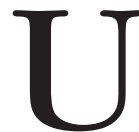

na de las disciplinas que más ha evolucionado en los últimos años es la archivística. Por un lado, el advenimiento masivo de los archivos digitales y, por el otro, el notable incremento de legislación mundial en materia de transparencia y rendición de cuentas de las agencias gubernamentales han traído profundos cambios en la conceptualización y el manejo de los archivos; incluso podemos hablar de replanteamientos al respecto a nivel social, administrativo, legal, gubernamental y, por supuesto, tecnológico. Muchas de las prácticas generales para su producción, manejo, preservación, permanencia, accesibilidad, autenticidad y fiabilidad, entre otras, se han modificado en las últimas dos décadas.

La investigación y el debate académico al respecto también aumentaron. Muchos proyectos se han realizado por iniciativa de organizaciones gubernamentales y académicas a nivel mundial con el fin de comprender, explicar y contender con la problemática derivada de estos cambios. A raíz de ello han surgido en unos cuantos años un sinnúmero de teorías, mo- 


\section{Glosario de Preservación...}

delos y conceptos que reconfiguran y replantean mucho de lo que ya se había establecido alrededor de los documentos de archivo y los fondos documentales, en particular aquéllos construidos digitalmente en su totalidad.

Asimismo, los cambios en la terminología sobre el tema resultan trascendentes. Muchos términos nuevos se han introducido a la archivística contemporánea, mientras que algunos términos antiguos han sido redefinidos, ampliando o cambiando las acepciones originales, para que incluyan significados actuales.

Empero, a pesar del auge de investigación, debate y publicaciones alrededor de esta temática, existe una notable carencia de diccionarios o glosarios al respecto. En la propia lengua inglesa, que es en donde más publicaciones hay al efecto, puede observarse que la producción no es abundante y es poco homogénea entre sí. La producción ha sido todavía más escasa en español. Hay que considerar que todo lo publicado en el siglo pasado está prácticamente desconectado de los archivos digitales y por lo mismo sólo es de utilidad al hablar de documentos de archivo sobre soportes tradicionales. Los diccionarios o glosarios de archivística en español de este siglo son muy contados y no existía ninguno que se especializara en la preservación archivística digital.

En lo relativo al tema de la preservación de documentos de archivo digitales, se creó hace poco más de una década el proyecto InterPARES -International Research on Permanent Authentic Records in Electronic Systems-Investigación Internacional acerca de Documentos de Archivo Permanentes $y$ Auténticos en Sistemas Electrónicos-. Éste ha sido un proyecto internacional que consiste en una colaboración transdisciplinaria para desarrollar teoría, prácticas, procesos y herramientas que sean útiles para asegurar un ambiente protegido y perdurable a largo plazo para documentos de archivo digitales auténticos, producidos por organizaciones públicas o privadas, y 
que tienen dentro de sus responsabilidades archivos digitales resultado de actividades gubernamentales, comerciales, de investigación, de arte o entretenimiento, sociales y comunitarias, entre otras. Tales archivos deben preservarse digitalmente de forma auténtica y a largo plazo con el fin de satisfacer los requerimientos de sus comunidades y las necesidades sociales para un adecuado registro de su pasado. El proyecto ha sido transdisciplinario en la medida que sus objetivos y metas pudieron alcanzarse solamente a través de la contribución de disciplinas, metodologías integradoras, conceptos, principios y técnicas provenientes de una amplia variedad de campos del conocimiento.

El proyecto se dedicó en sus primeras etapas a crear una conceptualización básica que comenzara a dar cierta homogeneidad y concierto tanto a los conceptos y términos que eran reconcebidos como a los nuevos términos introducidos como resultado de las actividades. Así, el proyecto creó una base de datos terminológica, ${ }^{1}$ con diversas presentaciones, relativa a la temática de la preservación de archivos digitales, la versión de México se presentó como un glosario integral de preservación de este tipo de archivos, uno específicamente de diplomática y otro de informática, todos ellos siempre alrededor de la archivística contemporánea y el documento de archivo digital. Estos glosarios significaron un gran avance en la homogeneización y comprensión de términos y conceptos; no obstante, los rápidos cambios en el medio de los archivos digitales motivan que varios términos deban ser precisados, replanteados o afinados más de una vez para responder a la realidad del medio archivístico al cual reflejan. Por lo mismo, en la tercera etapa del proyecto InterPARES se creó el glosario denominado

1 Base de Datos de Terminología InterPARES (en inglés) http://www.interpares.org/ip2/ip2_terminology_db.cfm 
InterPARES 3, el cual introdujo precisamente esa serie de actualizaciones a la terminología con respecto a etapas anteriores.

Como proyecto internacional, el glosario de terminología debía ser construido de origen en inglés con objeto de tener una base que pudiese servir internacionalmente, si bien desde el principio el proyecto se planteó como meta hacer las traducciones correspondientes a las diversas lenguas de las organizaciones que participaron en el esfuerzo. ${ }^{2}$ Para ello se inició una traducción del glosario al castellano a cargo del equipo mexicano que participó en el proyecto. No fue una labor fácil: tomar un diccionario inglés-español y traducir los términos, hubiese sido muy sencillo, pero absolutamente fútil; fue necesario conceptualizarlos y contextualizarlos no sólo en cuanto a las lenguas, sino a las culturas. Muchos de los términos, por ejemplo, tienen su origen en preceptos del derecho anglosajón o Common law, los cuales no pueden trasladarse tal cual a equivalentes en el derecho romano-canónico de los países hispanohablantes. Como ejemplo arquetípico tenemos el término central de toda la temática, record, que no tiene un equivalente exacto no sólo en español sino prácticamente en ninguna de las lenguas romances, y ha debido de ser traducido a la frase "documento de archivo". Como éste existen docenas de términos que han debido estudiarse minuciosamente para encontrar la equivalencia exacta o más cercana.

En otros casos se decidió que la traducción respetara la tradición, aun no siendo la más exacta desde un punto de vista técnico, salvo en los casos en que su uso era contrario a lo deseado en aras de la continuidad. Además, como sucede con muchas otras palabras en el idioma español, existen diversas variantes de las traducciones que ya son utilizadas en los diversos países hispanoparlantes. Todos los términos que

2 Base de Datos Internacional de Terminología InterPARES (múltiples lenguas) http://www.interpares.org/ip3/ip3_terminology_db.cfm 
fueron detectados en este contexto han sido incluidos en este glosario en español y se hicieron las notas correspondientes de los países en donde es usado otro término o una variante. Existen muchos términos que no tienen una equivalencia aceptable en castellano y hubo que establecer cuál de las palabras en esta lengua era la más aproximada para utilizarla como su traducción, a sabiendas de que otras palabras pueden ser utilizadas con el mismo propósito. Se evitó escrupulosamente la invención de neologismos para no complicar más el escenario, sólo se utilizan aquellos que fueron introducidos con anterioridad por otras disciplinas y que han sido aceptados oficialmente en el español, o bien que son ampliamente conocidos por el público en general.

El glosario presenta además tres ontologías elaboradas por el proyecto InterPARES en inglés, fueron traducidas y posteriormente actualizadas por el grupo mexicano del proyecto. Existen múltiples enfoques para las ontologías que comprenden distintas interpretaciones. Ontología es un término polisémico, cada una de sus interpretaciones tiene diversas manifestaciones y utilidades para distintos usos y disciplinas. Para nuestros fines utilizaremos la sencilla conceptualización que proviene de la definición de Tomas Gruber: "una ontología es una especificación explícita de una conceptualización". La importancia de las ontologías radica en el hecho de que todo conocimiento debe expresarse en conceptualizaciones que requieren de un vocabulario específico para ese campo. Las ontologías aportan una forma de facilitar esas conceptualizaciones y su vocabulario específico asociado ya que permiten hacer explícitos los supuestos y la estructura del tema a definir. Facilitan así analizar el conocimiento, darle orden y estructura e incrementar su reutilización. Su importancia futura radica en que con ellas podremos lograr en un cierto lapso que la información sea compartida entre las personas, entre los sistemas informáticos y entre ambos de una manera 


\section{Glosario de Preservación...}

unificada y coherente, lo que llevará a una recuperación más precisa, pertinente y oportuna de esa información.

Finalmente, cabe destacar que por la misma naturaleza de su objeto de estudio -los documentos de archivo digitales- esta terminología sigue cambiando y evolucionando conforme se introducen nuevas teorías, modelos y enfoques. No es estática en lo absoluto. Por ello ha sido necesario revisarla e introducir de cuando en cuando nuevas precisiones a algunos términos. En la versión en castellano del glosario InterPARES, publicado en el sitio web de esa organización, puede consultarse la versión 3.0; es decir, su tercera revisión mayor. Los términos en español de la Base de Datos Internacional de Terminología del Consejo Internacional de Archivos -ICA- ${ }^{3}$ provienen en esencia de esa versión. Igualmente sucede con el glosario alojado en el sitio web del Instituto de Investigaciones Bibliotecológicas y de la Información -IIBI- de la Universidad Nacional Autónoma de México -UNAM-. ${ }^{4}$ Además de los autores de la actual, participaron en esas versiones Brenda Cabral y Jovv Valdespino, ambos elementos fundamentales en las versiones anteriores de este glosario y a quienes expresamos nuestro agradecimiento.

Es imposible cerrar en definitiva el glosario y pensar en una "última" versión inamovible. La archivística digital sigue evolucionando, la preservación archivística digital también y lo mismo aplica para su terminología asociada. Si bien todas las copias mencionadas están disponibles en sendos sitios web, el IIBI/UNAM ha considerado pertinente editar esta versión impresa corregida y aumentada como una ayuda a las instituciones que desean tener una copia en papel de este material y para que

3 Base de Datos Internacional de Terminología del ICA (múltiples lenguas) http://www.ica.org/14282/multilingual-archival-terminology/multilingual-archival-terminology.html

4 Glosario InterPARES de Preservación Archivística Versión 3.0 (en español) http://iibi.unam.mx/archivistica/mex_glosario_interpares_total0112.pdf 
sirva como una memoria del estado que guarda la terminología al respecto en este año 2014. Dado que contiene diferencias sustanciales con la versión en línea existente a la fecha, decidimos denominarla "versión 4.0" para distinguirla a su vez de las anteriores. Por lo mismo se advierte al lector que tome nota de los cambios y actualizaciones para que en su uso práctico y cotidiano de los términos utilice las acepciones más actualizadas. Lo que vio en glosarios anteriores no necesariamente es igual a lo actual.

Cabe resaltar que este es un glosario de preservación archivística digital y sobre ese eje está construido. Por ello contiene muchos términos de archivística, pero no tantos como un diccionario general de la materia. Se centra en los documentos de archivos digitales, por lo que muchos términos que son exclusivos de archivos sobre soportes tradicionales no aparecen; incluye términos provenientes del campo legal, gubernamental, de la informática, de la diplomática, entre otros, que se consideraron pertinentes para comprender cabalmente la preservación archivística digital. En todos los casos se presenta además el término en inglés original para que el lector pueda comprender el contexto de uso de la palabra y, en su caso, haga las equivalencias correspondientes. La remisión Véase también dirige a otros términos que se consideraron útiles para complementar la comprensión; Véase remite a términos que se consideran estándar o más idóneos.

Muchos términos incluyen la disciplina de origen y la referencia original de donde fueron extraídos con objeto de que el lector abunde en su lectura si así lo desea. Conscientes de que este es un esfuerzo siempre perfectible, agradeceremos que envíen sus comentarios y observaciones técnicas a Alicia Barnard: barnard.alicia2@gmail.com

Se permite la reproducción de parte de este glosario siempre y cuando no se utilice para fines comerciales y se cite la fuente completa: 
Glosario de Preservación Archivística Digital Versión 4.0, México, UNAM/Instituto de Investigaciones Bibliotecológicas y de la Información, 2014.

De otra forma, requiere autorización por escrito del TEAM México del proyecto InterPARES.

Si el lector desea consultar la versión anterior en línea del glosario o las versiones parciales del mismo, puede encontrarlas en los sitios siguientes:

1. Glosario InterPARES Total Versión 3.0 en Español. Incluye la terminología desarrollada durante las tres fases del proyecto InterPARES acerca de los temas relacionados con la administración y preservación de los documentos de archivo digitales: Conceptos generales, Archivos, Informática, Diplomática y Forma documental. Es el más completo pero a la vez el más voluminoso. Recomendable para quienes se inician en la terminología de la preservación de los documentos de archivo digitales. Disponible en: http://iibi.unam.mx/archivistica

2. Glosario InterPARES 2 Total Versión en Inglés. Incluye la terminología original desarrollada en inglés por las tres fases acerca de los temas relacionados con la administración y preservación de los documentos de archivo digitales: Conceptos generales, Archivos, Informática, Diplomática y Forma documental. Recomendable para quienes desean conocer los términos internacionales en lengua inglesa de donde provienen las traducciones. Disponible en: http://www.interpares.org/ip2/ip2_terminology_db.cfm

3. Glosario InterPARES 3. Incluye sólo los términos actualizados y/o desarrollados durante la fase tres del proyecto InterPARES. Recomendable para quienes ya están familiarizados con la terminología de la preservación archivística digital y quieren conocer los términos actualizados 
para su mejor comprensión. Puede verse el glosario multilingüe en: http://www.interpares.org/ip3/ip3_terminolo gy_db.cfm y la versión sólo en español en: http://iibi.unam. $\mathrm{mx} /$ archivistica

4. Glosario InterPARES. Diplomática. Incluye sólo los términos relacionados con la ciencia diplomática y la forma documental. Recomendado para quienes están interesados sólo en este tipo de términos. Disponible en: http://iibi. unam.mx/archivistica

5. Glosario InterPARES. Informática. Incluye sólo los términos relacionados con la informática que a su vez tienen relación con la preservación archivística digital. Recomendado para quienes están interesados sólo en este tipo de términos. Disponible en: http://iibi.unam.mx/archivistica

6. Las Ontologías A, B y C ayudan a la mejor comprensión de los términos del glosario desde la perspectiva de la diplomática y la archivística para los documentos de archivo digitales. En el Anexo de esta obra se presentan las versiones actualizadas y en español de las originales editadas por el proyecto InterPARES (disponibles en http://www. interpares.org/ip2/ip2_terminology_db.cfm); pueden consultarse en el apartado "Glosario" de la página iibi.unam. $\mathrm{mx} /$ archivistica

Juan Voutssas M. y Alicia Barnard Amozorrutia México, 2014 


\section{GLOSARIO DE PRESERVACIÓN ARCHIVÍSTICA DIGITAL}

Versión 4.0 
Los conceptos entre corchetes corresponden a la categorización de las fuentes, es decir, remiten al campo de origen de los términos y se incluyen con el fin de contextualizar la definición.
[Archivos]
[Diccionario General]
[Diplomática]
[Gobierno]
[Informática]
[Ciencias]
Abreviaturas
s. Sustantivo
v. Verbo
a. Adjetivo
p. Página
op. Opuesto 


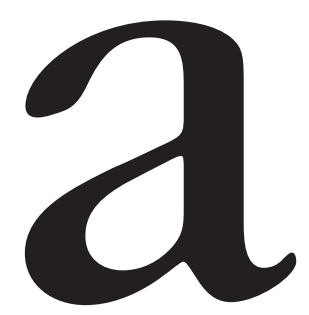

ACATAMIENTO

compliant

s. Acción y efecto de acatar leyes, regulaciones, estándares, etcétera [Diccionario General].

\section{ACCESIBILIDAD}

\section{accessibility}

s. 1. La disponibilidad y usabilidad de la información, en el sentido de la capacidad o facilidad actual y futura para que esa información pueda ser reproducida y por tanto usada [Archivos]. 2. En el ambiente web, la cualidad de un sitio de ser fácilmente accesible o usado con un mínimo de barreras, con la connotación de facilitar el acceso a individuos con discapacidades que les impedirían el uso normal, especialmente en los términos de la Recomendación del World Wide Web Consortium o W3C (Web Content Accessibility Guidelines (WCAG) 2.0) [Informática]. 3. La disponibilidad para consulta que tiene 
cierto material archivístico como resultado de una autorización legal y la existencia de auxiliares de consulta.

\section{ACCESO}

\section{access}

s. 1. El derecho, oportunidad o medios para encontrar, usar o allegarse documentos y/o información [ArchivosSociety of American Archivists, A Glossary of Archival E Records Terminology]. 2. El permiso para localizar y recuperar información para uso (consulta o referencia) dentro de las restricciones legalmente establecidas respecto de privacidad, confidencialidad y autorización [Archivos]. 3. El proceso de recuperar información que se encuentra en un medio de almacenamiento [Informática].

\section{ACCESO ABIERTO}

\section{open source}

s. Una filosofía de licenciamiento y distribución de programas y aplicaciones de cómputo, diseñada para impulsar su uso y desarrollo de manera colectiva y voluntaria con la garantía de que todos pueden copiar la fuente y modificarla libremente. También se les llama así a los programas y aplicaciones construidos bajo esta filosofía y que están disponibles para su uso y modificación de manera abierta y sin costo [Informática]. Véase también: "arquitectura abierta", "no propietario", "productos y formatos de acceso abierto".

\section{ACCIÓN}

\section{action}

s. 1. Ejercicio consciente de la voluntad de una persona encaminado a crear, mantener, modificar o extinguir cierta situación. Es uno de los componentes indispensa- 
bles de un documento de archivo: la acción -que siempre existe en un documento de archivo- lo distingue de otros tipos de documentos, los cuales no necesariamente deben tenerla. También se le denomina "acto" [Archivos]. 2. Objeto de la representación del documento el cual forma parte de su contenido sustantivo [Diplomática].

\section{ACEPTACIÓN}

\section{acceptance}

s. Un acuerdo o reconocimiento -ya sea por acto expreso o por implicación por conducta- de los términos de una propuesta y por lo cual se establece una relación contractual [Gobierno].

\section{ACOTACIÓN}

\section{marginalia}

s. Señal o apuntamiento que se pone al margen de algún escrito o impreso y que comenta, interpreta o completa un texto [Diccionario General].

ACTA

act

s. 1. Certificación, testimonio, asiento o constancia oficial de un hecho. 2. Legislación que se ha hecho ley, especialmente un estatuto [Gobierno].

\section{ACTA DE INGRESO}

\section{accession record}

s. Documento que consigna oficialmente, por parte de un preservador, la aceptación en custodia de un documento de archivo proveniente de un cierto grupo institucional claramente definido [Archivos]. Véase también: "documentos de archivo ingresados". 


\section{ACTA DE DISPOSICIÓN}

\section{disposition act}

s. Acta o documento oficial que registra la acción de ejecutar la destrucción final de documentos de archivo o su transferencia hacia un destino final en otro archivo de acuerdo con su valoración preestablecida. Véase también: "disposición", "tabla de retención”.

ACTIVIDAD

activity

s. Conjunto de acciones, operaciones o tareas propias de una persona o entidad y destinadas a un propósito [Archivos]. Véase también: "función".

ACTO

\section{action}

s. Ejercicio consciente de la voluntad de una persona encaminado a crear, mantener, modificar o extinguir cierta situación. El acto -que siempre existe en un documento de archivo- lo distingue de otros simples documentos. También se le denomina "acción" [Archivos].

\section{ACTORES}

actors

Véase: "personas".

\section{ACTUALIZACIÓN}

\section{upgrade}

s. Desarrollo o instalación de nuevas o mejores versiones de algún equipo o programa de cómputo [Informática]. Véase también: "conversión", "migración transformativa". 
ACUMULACIÓN DE FONDOS

\section{accrual}

s. También llamado "incremento de fondos" o "transferencia de fondos". La adquisición o traslado de nuevos fondos archivísticos de un productor hacia un preservador en adición a los fondos de ese productor que el preservador ya tenía en custodia [Archivos].

\section{ADJUNTO DEL CORREO ELECTRÓNICO}

\section{e-mail attachment}

Véase: "anexo de correo electrónico".

\section{ADMINISTRACIÓN ELECTRÓNICA}

\section{e-government}

Véase: "e-gobierno".

\section{ADMINISTRACIÓN DE DOCUMENTOS DE ARCHIVO}

\section{records management}

s. El campo de la administración responsable del control sistemático y eficiente de la producción, recepción, mantenimiento, uso y disposición de documentos de archivo; incluye procesos y controles para incorporar y mantener evidencia e información acerca de las actividades de una organización en forma de documentos de archivo [Archivos]. La norma UNE ISO-15489 tradujo este término como "gestión de documentos". También se le denomina "gestión archivística", si bien la administración es un concepto mucho más amplio y la gestión es en realidad un subconjunto de aquélla. Véase también: "mantenimiento de documentos de archivo". 


\section{ADMINISTRADOR DE DOCUMENTOS DE ARCHIVO}

\section{records manager}

s. Persona responsable por la administración de archivos activos y semiactivos provenientes de cierto productor. El papel de este administrador debe ser el de un custodio fiable. También se le conoce como "oficial de documentos de archivo" o "gestor de documentos de archivo"; en México se le llama archivista [Archivos]. Véase también: "archivista", "productor", "preservador designado de documentos de archivo".

\section{ADMISIBILIDAD}

\section{admissibility}

s. En el derecho procesal, una vez interpuesta una demanda o planteado un recurso, se denomina admisibilidad a la cualidad que tiene un documento de archivo o expediente de permitirse como evidencia en un juicio o audiencia, después de que un magistrado lo examina y determina que se han acatado los requerimientos y formalidades extrínsecas que la ley ordena para que el documento o expediente pueda pasar a tratamiento [Archivos-Diccionario Jurídico].

\section{ADQUIRIR}

acquire

v. Ganar, obtener o conseguir posesión o control sobre fondos archivísticos [Gobierno]. Véase también: "ingreso".

\section{ADQUISICIÓN}

\section{acquisition}

s. Adición o incremento a los fondos de un repositorio o centro archivístico [Archivos]. Véase también: "ingreso". 
AGENCIA CONTROLADORA

- Véase: "dependencia controladora".

AGENTE

agent

s. Persona física o jurídica que está autorizada para actuar, representar o gestionar en nombre de o en lugar de otra, y por tanto interviene en funciones y procedimientos relacionados con documentos de archivo [Archivos].

AGREGACIÓN DE ARCHIVOS

archival aggregation

a

s. El conjunto de los documentos de archivo comprendidos en una unidad de agregación archivística [Archivos]. Véase también: "documentos de archivo arreglados".

\section{AGREGACIÓN DE DOCUMENTOS DE ARCHIVO}

\section{records aggregation}

s. Una acumulación natural de un grupo interrelacionado de documentos de archivo, tales como un expediente, dossier, serie o fondo, como resultado de la manera en que el productor de los documentos realiza sus actividades o funciones. También se le conoce como "documentos de archivo agregados" [Archivos].

\section{ALMACENAMIENTO NO-VOLÁTIL}

\section{non-volatile storage}

s. Dispositivo de memoria secundaria de una computadora que no depende de suministro directo y continuo de energía eléctrica para mantener su contenido. También se le conoce como almacenamiento permanente o "almacenamiento secundario". Op.: "almacenamiento volátil" [Informática]. Véase también: "disco compacto", 
"cinta de audio digital", "cinta digital lineal", "videodisco digital", "disco duro".

ALMACENAMIENTO PERSISTENTE

persistent storage

Véase: "almacenamiento no-volátil".

\section{ALMACENAMIENTO PRIMARIO}

primary storage

Véase: "almacenamiento volátil".

ALMACENAMIENTO SECUNDARIO

secondary storage

Véase: "almacenamiento no-volátil".

\section{ALMACENAMIENTO VOLÁTIL}

volatile storage

s. Memoria de la computadora que requiere de suministro continuo de corriente para mantener su contenido; por ejemplo, el RAM. También se le denomina "almacenamiento primario". Op.: "almacenamiento no-volátil" [Informática].

\section{ALTERACIÓN}

\section{alteration}

s. Acción hecha a un documento de archivo después de ser completado, en consecuencia su significado, su lenguaje o su contenido han sido cambiados [Archivos].

\section{AMERICAN STANDARd CODE FOR INFORMATION INTERCHANGE}

\section{ASCII}

Código Estándar Americano para Intercambio de Información o ASCII. Código binario utilizado en la inmensa mayoría de las computadoras para representar los 
caracteres usados en todos los alfabetos occidentales descendientes del alfabeto latino: mayúsculas y minúsculas, dígitos, vocales con diacríticos, letras especiales como la "ñ", la "ç", la " $\Omega$ ”; caracteres especiales como “?” “!” “£”, “\$”, “\%”, “@”, etcétera. El uso de este código permitió el uso estandarizado e interoperable de textos entre distintas marcas de computadoras, módems, impresoras y otros aparatos. Originalmente, cada carácter ASCII estaba compuesto por 7 bits, lo que daba 128 combinaciones distintas. En la actualidad se usa el AsCII extendido de 8 bits o UTF-8, lo cual permite 256 combinaciones. Se ha conformado como el estándar ISO-Latin 8 dentro del estándar mundial de caracteres unicode [Informática].

\section{ANÁLISIS FORENSE DIGITAL}

\section{digital records forensics}

s. El uso de métodos científicos y probados para la preservación, colección, validación, identificación, análisis, interpretación, documentación y presentación de evidencia digital derivada de fuentes digitales, con el propósito de facilitar la reconstrucción o explicación de eventos supuestamente criminales, así como para ayudar a anticipar acciones no autorizadas que pudiesen ser disruptivas de las operaciones planeadas [Archivos].

\section{ANÁLOGO}

Véase: "analógico".

\section{ANALÓGICO}

\section{analog}

s. Cualidad de un dispositivo, instrumento de medida, mensaje, documento o su soporte en el cual la información involucrada se representa mediante variables continuas, semejantes o análogas a las magnitudes correspondientes. 
Se contrapone con "digital", en donde el ente involucrado representa la información con dígitos. El ente analógico puede ser electrónico o no; en caso de serlo usa una representación de la información que no se basa en dígitos. Véase también: "dato analógico", "documento analógico", "documento de archivo analógico” [Informática].

\section{ANEXO}

\section{attachment}

s. Aquel documento que, al ser físicamente conectado a un documento de archivo por medio de un acto, pasa a formar parte de ese documento de archivo [Archivos].

\section{ANEXO DE CORREO ELECTRÓNICO}

\section{e-mail attachment}

s. Un documento o conjunto de ellos que está vinculado a un mensaje de correo electrónico y que se transmite simultáneamente con él. Este anexo puede ser de cualquier tipo: texto, imagen, sonido, etcétera.

\section{ANOTACIÓN}

\section{annotation}

s. 1. Cualquier adición hecha a un documento de archivo después de que ha sido producido [Archivos]. Véase también: "fase de ejecución", "apostilla", "anotación de producción", "anotación de manejo", "anotación de gestión”, Ontología A.

\section{ANOTACIÓN AL MARGEN}

\section{marginalia}

s. Acotación, señal, comentario o apuntamiento escrito al margen de un escrito o impreso y que lo comenta, interpreta o completa [Diplomática]. Véase también: "apostilla". 
ANOTACIÓN DE PRODUCCIÓN

\section{execution annotation}

s. Adición hecha a un documento de archivo como parte de la fase de ejecución del procedimiento administrativo, por ejemplo, fecha, lugar, hora y prioridad de transmisión añadidas a un documento de archivo en el momento de su envío, las fechas de compilación y transmisión en un documento de archivo de correo electrónico, la indicación de los anexos añadidos a un determinado documento de archivo, los signos del compilador o mecanógrafo, etcétera [Archivos]. Véase también: "apostilla", Ontología A.

\section{ANOTACIÓN DE MANEJO}

\section{business matter annotation}

s. Adición hecha a un documento de archivo en el curso del manejo de la materia de negocio en la que participa; refleja las acciones tomadas con posterioridad a su producción con el fin de manejar la actividad o materia inherente al documento, por ejemplo, el nombre de la oficina receptora del asunto, la fecha y hora de la recepción del expediente por esa oficina, las fechas de retransmisión a otras oficinas, las medidas o acciones adoptadas con el documento de archivo y sus fechas, comentarios observados en portada o cuerpo del documento, signos especiales de destinatarios, etcétera.

\section{ANOTACIÓN DE GESTIÓN}

\section{record management annotation}

s. Adición hecha a un documento de archivo en el curso de su tratamiento precisamente como un documento de archivo. Es el reflejo de las acciones emprendidas con posterioridad a la producción del documento de archivo para los efectos de su gestión como parte de los fondos 
de documentos de archivo de una agencia; por ejemplo, el código de clasificación o el número de registro asignado al documento, su folio consecutivo, la agregación a la que pertenece, fecha de archivado, número de versión o borrador, referencias cruzadas a otros documento de archivo, indicación de acciones agendadas y nombre del productor, entre otra información.

ANSI

ANSI

Acrónimo de American National Standards Institute (Instituto Nacional Norteamericano de Estándares).

\section{APARIENCIA O PRESENTACIÓN PERCEPTIBLE POR LOS SENTIDOS}

\section{appearance or presentation perceptible by the senses}

s. Parte de la forma física de un documento de archivo; incluye aspectos que determinan el arreglo espacial y visual de los elementos perceptibles del documento de archivo, como logos, cajas, colores, zonas, viñetas, distribución, representados en forma de scripts, distribución o layouts, hojas de estilo o cascada, y otras propiedades significativas del documento de archivo.

\section{APARTAR}

\section{set aside}

v. Declarar un documento de archivo y retenerlo -separarlo, guardarlo- para futura referencia o uso, generalmente en un sistema de mantenimiento de documentos de archivo [Archivos].

\section{API}

s. Acrónimo de Application Programming Interface o “interfaz de programación” [Informática]. 
APLICACIÓN

application

s. Pieza de programación de cómputo que permite a un usuario capturar, procesar o visualizar datos, realizar cálculos y otras acciones tendientes a obtener un resultado específico preestablecido [Informática].

\section{APLICACIÓN HEREDADA}

legacy application

s. Una aplicación o programa informático que aún está en uso dentro de una organización, construido en un lenguaje o una plataforma que ya no es actual para el fabricante.

APOSTILLA

\section{annotation-marginalia}

s. 1. (De annotation) Método estandarizado y simplificado para legalización de documentos a efectos de verificar su autenticidad internacionalmente. Consiste en una hoja que una autoridad competente emite y agrega al reverso o como página adicional de un documento para dar fe de su autenticidad. Se deriva de un acuerdo internacional denominado Convenio de la Haya [Archivos]. 2. (De marginalia) Acotación que comenta, interpreta o completa un texto [Diccionario General].

\section{APRECIACIÓN}

\section{appreciation}

s. Uno de los elementos internos de la forma documental que consiste en una intención o deseo de que se realice o entienda el contenido de un documento [Diplomática]. Véase también: Ontología A. 


\section{ARCHIVADOR}

\section{filing cabinet}

s. Mueble de oficina diseñado a propósito para contener documentos de archivo y que puede variar dependiendo de los soportes y formatos de esos documentos. Este término se usa ampliamente en España. En México se utiliza "archivero" para describir dicho mueble.

\section{ARCHIVAR}

\section{file/archive}

v. (De to file) Guardar (separar, apartar) un documento elaborado o recibido hacia un conjunto con documentos de archivo activos que participan en la misma acción o asunto o están relacionados con una misma persona o sujeto, de forma que tal documento pueda ser recuperado para futura acción o referencia [Archivos].

v. (De to archive) Guardar (preservar) a largo plazo documentos de archivo que no se encuentran ya activos. El concepto aplica tanto para documentos de archivo tradicionales como para digitales [Archivos].

\section{ARCHIVERO}

\section{archivist}

s. Profesional de las ciencias archivísticas y/o el responsable de la administración de un archivo; este nombre es muy utilizado en España, mientras que en México se emplea "archivista". También se le conoce como "archivónomo" o "archivólogo". [Archivos]. Véase también: "preservador designado de documentos de archivo", "custodio", "administrador de documentos de archivo". 


\section{ARCHIVISTA}

\section{archivist}

s. Profesional de las ciencias archivísticas y/o el responsable de la administración de un archivo administrativo o histórico. También se le conoce como "archivónomo", "archivólogo" y "archivero" [Archivos]. Este nombre es muy utilizado en México; en España se utiliza "archiverador". Véase también: "preservador designado de documentos de archivo", "custodio", "administrador de documentos de archivo".

\section{ARCHIVÍSTICA}

\section{archival science}

s. Disciplina que apoya la metodología y práctica de la valoración, adquisición, autenticación, preservación y acceso a los materiales documentales archivados [Archivos]. En México y otros países se le conoce también como "archivonomía". Véase también: "ciencia archivística".

ARCHIVo [de file (conjunto documental)]

file

Véase: "expediente".

ARCHIVO [de file (objeto de información dentro de una computadora)]

file

s. Objeto de información con un nombre dentro de una computadora, el cual almacena de forma autocontenida datos, información, instrucciones u otros elementos que serán usados por un sistema operativo o programa de cómputo [Informática]. En España y otros países se le deno- 
mina "fichero". En el ambiente archivístico, para distinguirlo de un "expediente" o file con frecuencia se le denomina redundantemente como archivo de computadora.

ARCHIVO [de archive]

\section{archives}

s. (De archive, puede interpretarse como institución, lugar o colección) 1. (Institución) Instancia responsable de la preservación y distribución de documentos de archivo seleccionados para su preservación permanente. 2. (Lugar) Un sitio específico donde se encuentran los documentos de archivo seleccionados para preservación permanente. 3. (Colección) El fondo documental o series de ellos conformados por conjuntos de documentos de archivo provenientes de una o varias organizaciones, que han sido elaborados y recibidos por ellas en el desarrollo de sus actividades y que son preservados.

\section{ARCHIVO DIGITAL}

\section{digital archive}

s. Un archivo que existe en formatos y soportes digitales.

\section{ARCHIVO ORIGINAL}

\section{original file}

s. En el ambiente de los soportes en papel, es un fondo documental que contiene originales (archivos de documentos recibidos así como borradores y/o originales de documentos enviados) [Archivos-Duranti, Diplomatics: New Uses for an Old Science, p. 167].

\section{ARCHIVO PERSISTENTE}

\section{persistent archive}

s. Estrategia que busca que la arquitectura de los sistemas de información usados para la preservación de do- 
cumentos de archivo sea independiente de la tecnología utilizada para implementar dichos sistemas. Véase también: "preservación de objeto persistente".

\section{ARCHIVOLOGÍA}

archival science

Véase: "ciencia archivística".

\section{ARCHIVÓlOGO}

Véase: "archivista".

\section{ARCHIVONOMÍA}

Véase: "archivística".

\section{ARCHIVÓNOMO}

Véase: "archivista".

\section{ARGUMENTOS DE LLAMADA}

\section{calling convention}

s. En programación de sistemas y aplicaciones, se llama así al conjunto de parámetros o valores que se pasan al momento de llamar a un procedimiento (procedure) o función [Informática].

\section{ARQUEOLOGÍA DIGITAL}

digital archaeology

Véase: "recuperación de datos".

\section{ARQUITECTURA}

\section{arcbitecture}

s. Un cierto diseño conceptual, estructura de equipo y programas de cómputo que de acuerdo con su tipo tienen definidas ciertas características, comportamiento y forma de interactuar de sus componentes [Informática]. 


\section{ARQUITECTURA ABIERTA}

\section{open architecture}

s. Una estructura informática cuyas especificaciones son públicas. Esto incluye los estándares oficialmente aprobados y las arquitecturas de índole privada cuyas especificaciones han sido divulgadas al público por sus diseñadores; por ejemplo, el sistema operativo Linux o el formato de documentos odt [Informática]. Véase también: "acceso abierto", "no propietario", "productos y formatos de acceso abierto".

ARREGLO

arrangement

Véase: "arreglo archivístico".

\section{ARREGLO ARCHIVÍSTICO}

\section{archival arrangement}

s. El proceso de identificar los documentos de archivo que se encuentran en etapa histórica según pertenecen a los grupos dentro de un fondo [Archivos].

\section{ARTEFACTO}

\section{artifact}

s. Son los conceptos y vocabulario específico dentro de una ontología que se usan para representar conocimiento común y compartido acerca de un campo del conocimiento o "dominio". Específicamente, un artefacto consiste por lo general en una estructura conceptual muy completa y exhaustiva dentro de un cierto campo del conocimiento, y se construye para comunicar y compartir con mayor facilidad la información entre usuarios, las bases de datos y los sistemas informáticos dentro de ese "dominio". Es decir, su aplicación pretende ir más allá de una organi- 
zación o región: una comunidad específica interesada en ese campo de conocimiento.

ASCII

ASCII

Véase: "American Standard Code for Information Interchange".

ASUNTO

subject line

s. Uno de los elementos internos de la forma documental que consiste en la descripción general del tópico o temática de la que trata el documento, tal como funciones, actividades, etcétera [Diplomática]. También se le denomina "tema" o "materia" [Archivos-Duranti, Diplomatics: New Uses for an Old Science, p. 144]. Véase también: Ontología A.

\section{ATESTACIÓN}

\section{attestation}

s. Uno de los elementos internos de la forma documental que comprende la exposición o declaración de una persona que testifica o afirma algo, o la validación escrita de un documento de archivo mediante suscripción o suprascripción de cualquier signo identificado para esa función por parte de aquellos que toman parte en su en su emisión (autor, escritor, controlador de firmas, etcétera) así como por los testigos de la acción o la firma del documento de archivo [Diplomática]. En archivos tradicionales, aparece al final en el "escatocolo"; en documentos digitales, al principio del mismo, como en el encabezamiento de un correo electrónico [Archivos]. Véase también: Ontología A. 


\section{ATRIBUTOS}

\section{attribute}

s. Características físicas y conceptuales que conforman un documento de archivo, lo identifican de forma inequívoca y lo distinguen de otros. La combinación de atributos es irrepetible para cualquier otro documento de archivo y documenta y conlleva la identidad de cada documento de archivo. Los atributos se manifiestan en dos tipos de componentes: intelectuales y digitales. Entre los primeros están, por ejemplo, el nombre de todos los que toman parte en la emisión del documento (autor, escritor, destinatario, productor, originador), sus fechas (elaboración y/o producción, recepción, separado, transmisión), su asunto o tema, su vínculo archivístico con otros documentos del mismo grupo, la indicación de anexos y otros elementos. Entre los digitales están los archivos de texto, imágenes, fuentes tipográficas, entre otras características. Los atributos pueden estar contenidos en alguno de los elementos del documento de archivo, en sus metadatos o en alguno de sus contextos [Diplomática]. Véase también: Ontología A.

\section{ATRIBUTO DE UN DOCUMENTO DE ARCHIVO}

\section{record attribute}

s. Característica definitoria de un documento de archivo o de un elemento del mismo, lo identifica de forma inequívoca y lo distingue de otros, como el nombre del autor o la fecha o asunto del documento de archivo [Diplomática]. Véase también: "forma documental", Ontología A.

\section{AUDIOVISUAL}

\section{audiovisual}

a. Acerca de, o relacionado con el uso de sonido e imágenes visuales para presentar información [Diccionario General]. 


\section{AUTENTICACIÓN}

\section{autbentication}

s. Declaración de autenticidad de un documento de archivo en cierto punto específico del tiempo, realizada por una persona con calidad jurídica y con autoridad para hacer tal declaración (por ejemplo, un servidor público, un notario o una autoridad certificadora). Véase también: "certificado de autenticidad".

\section{AUTENTICACIÓN DEPENDIENTE DE TECNOLOGÍA}

\section{technology-dependent autbentication}

s. El uso de herramientas tecnológicas tales como la firma digital y otras técnicas criptográficas con el fin de autenticar documentos de archivo [Archivos]. Véase también: "autenticación independiente de tecnología".

\section{AUTENTICACIÓN INDEPENDIENTE DE TECNOLOGÍA}

\section{technology-independent autbentication}

s. La autenticación de documentos de archivo basada exclusivamente en el uso de procedimientos administrativos, específicamente por medio de la comparación de la evidencia recopilada acerca de la identidad e integridad de un documento de archivo y de los controles procedimentales ejercidos durante su producción, uso, mantenimiento y preservación con respecto a los requisitos para documentos de archivo auténticos; todo ello con el propósito de establecer la presunción de autenticidad y, si fuese necesario, la certificación de autenticidad [Archivos]. Véase también: "requisitos básicos de autenticidad", "requisitos de referencia de autenticidad", "autenticación dependiente de tecnología". 


\section{AUTENTICAR}

\section{autbenticate}

v. Declarar, ya sea oralmente, por escrito o por fijación de un sello, que cierta entidad documental es lo que se propone ser, sin alteraciones o corrupciones, después de haber verificado su identidad e integridad [Archivos]. Véase también: "certificado de autenticidad".

\section{AUTENTICIDAD}

\section{autbenticity}

s. Junto con la "fiabilidad" y la "exactitud" es uno de los elementos que conforman la "confianza" de un documento de archivo; consiste en acreditar que un documento de archivo es lo que pretende ser sin alteraciones ni corrupciones. Los documentos auténticos son los que han mantenido su identidad e integridad al paso del tiempo gracias a la evidencia de su carácter, requisitos o circunstancias inherentes. Dicho de otra forma, la autenticidad es la confianza en que un documento de archivo realmente lo sigue siendo [Archivos]. Véase también: "identidad", "integridad", "certificado de autenticidad", Ontología C.

\section{AUTOAUTENTICACIÓN}

\section{self-autbentication}

s. Autenticación hecha sin evidencia intrínseca de verdad o genuinidad. Ciertos escritos, tales como documentos notarizados y copias certificadas de documentos de archivo públicos, pueden ser admitidos como evidencia por autoautenticación en juzgados y tribunales federales [Gobierno-Black's Law Dictionary]. 


\section{AUTODESCRIPTIVO}

\section{self-describing}

s. Un objeto cuya estructura de datos, forma o distribución aporta tanto definiciones y valores para datos o formatos del objeto documental. Una entidad autodescriptiva puede ser evaluada con todos sus elementos y formas comprendidas sin la necesidad de referencias externas [Informática]. Véase también: "formato persistente", "objeto persistente".

\section{AUTOR}

\section{autbor}

s. Una de las cinco personas que debe tener un componente de archivo digital. Es la persona física o jurídica que tiene la autoridad y capacidad para emitir un documento de archivo o en cuyo nombre u orden el documento de archivo ha sido emitido [Archivos]. Véase también: Ontología A.

\section{AUTORIDAD}

\section{autbority}

s. El derecho o permiso de actuar legalmente por parte de otro. El poder otorgado a una persona para incidir en las relaciones con otros actuando con el consentimiento de un tercero que delegó. El poder delegado por un principal a un agente [Archivos].

\section{AUTORIDAD CERTIFICADORA DIGITAL}

\section{digital certification autboritby}

s. Persona jurídica confiable que verifica la identidad del solicitante de un certificado digital y en su caso lo expide en consecuencia con una cierta vigencia. El certificado 
digital es un sistema de verificación de esa identidad y vigencia del cual el interesado posee una copia utilizable para firmar un documento digital. Los terceros interesados pueden verificar, en cualquier momento con la autoridad correspondiente, si un cierto documento digital firmado es legítimo en cuanto a la identidad del firmante. Procesos semejantes se hacen con respecto a oficinas en forma de sellos digitales. 


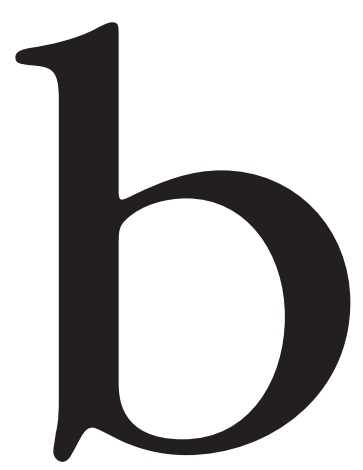

BASE DE DATOS

database

s. Colección de unidades de datos afines, interrelacionados y estructurados de forma tal que permiten el rápido acceso, la manipulación y la extracción de ciertos subconjuntos de esos datos por parte de programas creados para tal efecto o de lenguajes de comandos de búsqueda rápida (query) [Informática].

BASE DE DATOS OPERATIVA

back-end database

s. Base de datos que contiene y maneja datos esenciales para un sistema de información, los cuales deben ser independientes de las interfaces o presentación de ese sistema [Informática].

BIT

bit

s. (Contracción de binary digit) La mínima unidad de información que una computadora puede procesar y al- 
macenar en su interior. Consiste en dígitos binarios (1 y 0) con los cuales, de acuerdo a un código convencional preestablecido, se puede representar y procesar información de todo tipo [Informática]. Véase también: "byte", "cadena de bytes", "cadena de bits", "mapa de bits", "bit de paridad".

\section{BIT DE PARIDAD}

parity bit

s. Técnica usada en transmisiones digitales para verificar si se produjo algún fallo en la comunicación y si la información enviada es correcta o no. Consiste en un "bit" que se agrega a un conjunto de datos digitales transmitidos, el cual es construido de tal forma que permite al destinatario reconocer eventuales errores de transmisión [Informática].

\section{BORRADOR}

\section{draft}

s. Documento de archivo elaborado para fines de corrección [Archivos]. Véase también: Ontología B.

BYTE (carácter)

\section{byte}

s. También llamado "octeto". Es la mínima unidad de almacenamiento digital que puede ser direccionable dentro de una computadora. Un byte típicamente guarda un carácter de escritura y mide por lo general ocho bits. En el aspecto técnico es un elemento en la jerarquía de direccionamiento de datos dentro de las computadoras, más grande que un bit y menor que una palabra de máquina [Informática]. 


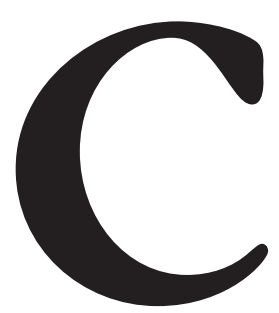

CADENA DE BITS

bitstream

s. Datos digitales codificados en una secuencia no estructurada de bits o dígitos binarios y que son transmitidos, almacenados o recibidos como una unidad. [Informática]. Véase también: "cadena de bytes", "cadena de datos".

CADENA DE BYTES (cadena de caracteres)

byte stream

s. Secuencia o cadena de bits cuyos datos (bits o dígitos binarios) están agrupados en unidades estructuradas de longitud fija y predeterminada llamadas bytes o caracteres [Informática].

CADENA DE DATOS

data stream

s. Secuencia o cadena de señales digitalmente codificadas que se usan para representar información en una 
transmisión [Informática]. Véase también: "cadena de bits", "cadena de bytes".

\section{CADENA DE PRESERVACIÓN}

\section{chain of preservation}

s. Modelo de una secuencia o sistema de controles que se extiende sobre todo el ciclo de vida de los documentos de archivo para asegurar su identidad e integridad a lo largo del tiempo [Archivos-cadena de preservación]. Este modelo considera un sistema de administración de documentos de archivo tripartita, formado por un sistema de elaboración de documentos de archivo, un sistema de mantenimiento y un sistema de preservación. Véase también: "sistema de elaboración de documentos de archivo", "sistema de mantenimiento de documentos de archivo", "sistema de preservación de documentos de archivo", "control administrativo", "control intelectual", "preservación de documentos de archivo", "custodia ininterrumpida".

\section{CAMPO}

field

s. Un espacio para datos de diversos tipos (caracteres o bytes, palabras, códigos, etcétera) que son considerados como una sola unidad, como un nombre, una dirección o un número [Informática]. Véase también: "elemento de dato".

\section{CAPTURA}

\section{capture (noun)}

s. Acto de salvar una instanciación o estado de un componente digital o grupo de ellos [Archivos]. 


\section{CAPTURA DE DOCUMENTOS}

\section{documents capture}

s. Proceso de identificación de un documento de archivo elaborado por un productor en un sistema de producción de documentos de archivo y su integración -ser fijado de manera sintácticamente estable en un medio de almacenamiento digital no volátil- de acuerdo con las especificaciones de actividades, procedimientos documentales y privilegios integrados emitidos por ese productor [Archivos].

\section{CAPTURAR}

capture (verb)

v. Identificar un documento de archivo elaborado por un productor en un sistema de producción de documentos de archivo e integrarlo -fijarlo de manera sintácticamente estable en un medio de almacenamiento digital no volátil- de acuerdo con las especificaciones de actividades, procedimientos documentales y privilegios integrados, emitidos por ese productor [Archivos].

\section{CARÁCTER}

\section{character}

s. Uno de los elementos de un conjunto de símbolos, tales como letras, números o signos de puntuación, que se utilizan para expresar datos y/o información. También se le denomina caracter [Diccionario General].

\section{CARÁCTER PRIMITIVO}

\section{primitiveness}

s. La cualidad de ser primero, original, no derivado de otra cosa. Junto con la "completitud" y la "efectividad" es 
una cualidad básica de un documento de archivo original. También se le conoce como "originalidad" [Archivos]. Véase también: Ontología B.

\section{CARACTERÍSTICA DE UN DOCUMENTO DE ARCHIVO}

\section{record characteristic}

s. Una de las cualidades inherentes a todos los documentos de archivo, tal como una forma documental fija, un contenido estable, un vínculo archivístico con otros documentos de archivo (tanto dentro como fuera del sistema) así como un contexto identificable [Diplomática].

\section{C}

\section{CARACTERÍSTICAS ESPECÍFICAS DE PRESENTACIÓN} specific presentation feature

s. Uno de los elementos externos de la forma documental que comprende los diversos aspectos de la presentación del documento y que son necesarios para lograr su propósito, tales como plantillas específicas, hipervínculos, colores y fuentes tipográficas expresamente establecidos; resolución de imágenes, tasas de muestreo de elementos de audio, entre otros [Diplomática]. Véase también: "presentación general".

\section{CARPETA}

folder

s. Cubierta dentro de la cual se guardan libremente documentos de archivo no electrónicos que pertenecen al mismo expediente, por lo general ordenados cronológicamente. Un expediente o dossier puede estar distribuido a lo largo de varias carpetas o legajos [Archivos]. Véase también: "expediente". 
CATÁLOGO DE DISPOSICIÓN DOCUMENTAL

retention schedule

records retention schedule

s. Documento que describe series o clases de documentos de archivo y especifica sus términos de retención (guardado en el archivo) y de disposición (destrucción o transferencia a un destino final); las fechas o eventos que los detonan así como las acciones a realizar al término de ese lapso [Archivos-cadena de preservación]. En México se le conoce con este nombre; en el resto de países de habla hispana se le conoce como "tabla de retención".

CD

\section{CD}

s. Acrónimo de compact disc-"disco compacto" [Informática].

CEN

Acrónimo de Comité Européen de Normalisation (European Committee for Standardization o Comité Europeo de Normalización).

CÉDULA DE DISPOSICIÓN

Véase: "tabla de retención".

\section{CERTIFICACIÓN}

\section{qualification}

s. Elemento opcional de los componentes digitales de un documento de archivo. Consiste en algún elemento o procedimiento emitido por un tercero confiable para atestiguar la identidad de una persona y/o la autenticidad del origen de un cierto documento. En el medio electrónico 
la certificación digital también es emitida por una autoridad certificadora digital confiable y atestigua la firma o sello electrónicos de una persona u oficina y el origen auténtico de un documento digital. Pueden presentarse en forma de firma o sello digital, certificados electrónicos, sellos de tiempo digitales, marcas de agua electrónicas, técnicas de cifrado, cuentas verificadoras (checksum) u otros métodos de autenticación.

\section{CERTIFICACIÓN DE FIRMA}

\section{qualification of signature}

s. Uno de los elementos internos de la forma documental que comprende la mención del título y competencia del firmante; se acompaña usualmente de atestación [Diplomática] [Archivos-Duranti, Diplomatics: New Uses for an Old Science, p. 149]. Véase también: Ontología A.

\section{CERTIFICADO DE AUTENTICIDAD}

\section{certificate of autbenticity}

s. Declaración que hace el productor o el preservador acerca de que una o varias copias reproducidas o reproducibles de un cierto documento de archivo digital son auténticas [Archivos]. Véase también: "autenticar", "autenticación".

\section{CERTIFICADO DE AUTENTICIDAD DEL PRESERVADOR}

\section{preserver's certificate of authenticity}

s. Atestación del preservador reconociendo que uno o más documentos de archivo son auténticos [Archivosmodelo de la cadena de preservación]. 


\section{CICLO DE VIDA DE LOS DOCUMENTOS DE ARCHIVO}

\section{records lifecycle}

s. Un modelo de administración de documentos de archivo y de la ciencia archivística que caracteriza el tiempo de vida de un documento de archivo y que comprende ocho etapas: 1) producción o recepción, 2) clasificación, 3) mantenimiento, 4) disposición por medio de la destrucción o transferencia a una agencia, institución archivística o archivo histórico, 5) descripción del documento en auxiliares de consulta, 6) preservación, 7) referencia y 8) uso [Archivos]. Véase también: "documento de archivo activo", "documento de archivo semiactivo", "documento de archivo inactivo", "continuidad de los documentos de archivo".

\section{CIENCIA}

\section{science}

s. Cuerpo de conocimiento que comprende hechos medibles o verificables, adquiridos a través de la aplicación del método científico, y generalizados por medio de leyes o principios científicos [Ciencias].

\section{CIENCIA ARCHIVÍSTICA}

\section{archival science}

s. Cuerpo de conocimiento teórico que estudia los conceptos, principios y metodologías relacionados a los documentos de archivo, así como sus relaciones documentales y funcionales [Archivos-Duranti \& MacNeil, "The protection of the integri of electronic records"]. En América se le conoce también como "archivología". Véase también: "archivística". 
CIENCIA FORENSE DIGITAL

Véase: "análisis forense digital".

CIENCIA FORENSE DIGITAL DE DOCUMENTOS DE ARCHIVO

Véase: "análisis forense digital".

\section{CIFRADO UTILIZANDO LLAVE PÚBLICA}

\section{public key encryption (PKE)}

s. Un método para cifrar o encriptar mensajes o textos a base de dos llaves o contraseñas: una pública, conocida por todo mundo y que es usada por el emisor del mensaje para cifrarlo o encriptarlo, y una privada, conocida únicamente por el receptor del mensaje y que le sirve para descifrarlo o desencriptarlo. Otro par de llaves no funcionará [Informática]. También se le conoce como "encriptado utilizando llave pública". Véase también: "encriptado utilizando llave pública", "infraestructura de llave pública”.

\section{CIFRAR}

\section{encrypt}

v. Transformar un mensaje que se quiere ocultar, mediante las reglas de un código, formulación o clave, hacia guarismos, letras o símbolos, por lo general con la intención de volverlo ininteligible a extraños y poder así transmitirlo o almacenarlo de forma segura. Sólo el que conoce el código o clave puede descifrarlo nuevamente.

\section{CINTA DE AUDIO DIGITAL}

\section{digital audio tape}

s. También conocida como "DAT" por sus siglas en inglés. Cinta plástica recubierta con un medio de grabación ferromagnético, con capacidad de hasta 4 Gigabytes de datos ( $4 \times 10^{9}$ bytes) grabados digitalmente, por lo gene- 
ral usando el método de escaneo helicoidal [Informática]. Véase también: "cinta digital lineal", "almacenamiento no-volátil".

\section{CINTA DIGITAL LINEAL}

\section{digital linear tape}

s. También conocida como "DLT" por sus siglas en inglés. Cinta plástica recubierta con un medio de grabación ferromagnético, con capacidad de hasta 35 Gigabytes de datos $\left(35 \times 10^{9}\right.$ bytes $)$ grabados digitalmente en cada cartucho, por lo general usando el método de grabación longitudinal [Informática]. Véase también: "cinta de audio digital", "almacenamiento no-volátil".

CLASE

\section{class}

s. Grupo o categoría al que pertenece un cierto conjunto de documentos de archivo de acuerdo a métodos, procedimientos, criterios o convenciones preestablecidas y representadas en un plan, cuadro o esquema de clasificación.

\section{CLASIFICACIÓN}

\section{classification}

s. Organización sistemática de documentos de archivo en grupos o categorías jerárquicas de acuerdo a métodos, procedimientos, criterios o convenciones preestablecidas y representadas en un plan, cuadro o esquema de clasificación [Archivos].

\section{CLASIFICAR}

\section{classify}

v. Arreglar sistemáticamente los documentos de archivo en grupos o categorías de acuerdo a métodos, procedi- 
mientos, criterios o convenciones preestablecidos en un cuadro de clasificación [Archivos].

\section{CLÁUSULA}

\section{clause}

s. Una de varias fórmulas textuales que se encuentran dentro de la distribución de un documento para asegurar la ejecución de un acto, prohibir su violación, garantizar su validez, salvaguardar los derechos de terceros, atestiguar cierta formalidad requerida o indicar los medios empleados para dar al documento validez probatoria [Diplomática]. Véase también: "cláusula de cortesía", "cláusula final".

\section{CLÁUSULA COMPLEMENTARIA}

\section{complimentary clause}

Véase: "cláusula de cortesía".

\section{CLÁUSULA DE CORTESÍA}

\section{complimentary clause}

s. Breve fórmula en la escritura que expresa respeto, por ejemplo: atentamente, sinceramente suyo, etcétera [Diplomática]. Véase también: "cláusula".

\section{CLÁUSULA FINAL}

\section{final clause}

s. Una de varias fórmulas textuales que se encuentran después de la distribución de un documento para asegurar la ejecución de un acto, prohibir su violación, garantizar su validez, salvaguardar los derechos de terceros, atestiguar cierta formalidad requerida o indicar los medios empleados para dar al documento validez proba- 
toria [Diplomática]. Véase también: "cláusula”, "cláusula de cortesía”.

\section{CLAUSULADO}

clause set

s. Conjunto de fórmulas textuales que se encuentran dentro de la distribución de un documento para asegurar la ejecución de un acto, prohibir su violación, garantizar su validez, salvaguardar los derechos de terceros, atestiguar cierta formalidad requerida o indicar los medios empleados para dar al documento validez probatoria [Diplomática].

\section{CODIFICACIÓN}

\section{encoding}

v. Transformar, mediante las reglas de un código, la formulación de un mensaje [Diccionario General]. Véase también: "codificación analógica", "codificación binaria", "codificación por series de bytes", "texto cifrado", "codificación digital", "codificación duradera", "esquema de codificación de metadatos".

\section{CODIFICACIÓN ANALÓGICA}

\section{analogue encoding}

s. El uso de patrones mecánicos o de señales electrónicas continuas variables para representar información; por ejemplo, la grabación de una película en videocasete. Es lo opuesto de la codificación digital, que usa señales numéricas discretas - no continuas-como las usadas por computadoras y otros sistemas digitales [Informática]. Véase también: "codificación binaria", "codificación digital", "codificación por series de bytes". 


\section{CODIFICACIÓN BINARIA}

\section{binary encoding}

s. Proceso de convertir datos analógicos en datos digitales, usando algún tipo de convención de codificación basada en dígitos binarios ( 1 y 0 ), a fin de almacenar y procesar esos datos en una computadora y/o transmitirlos en redes de comunicaciones modernas [Informática]. Véase también: "codificación analógica", "codificación digital", "codificación por series de bytes".

\section{CODIFICACIÓN CRÍPTICA}

\section{encryption}

s. La conversión de datos a un código secreto; esto es, la conversión de texto plano a texto cifrado, con la intención de volverlo ininteligible a extraños para su transmisión a través de redes públicas o su almacenamiento seguro [Informática]. También se le conoce como encriptado. Véase también: "codificar".

\section{CODIFICACIÓN DIGITAL}

\section{digital encoding}

s. Consiste en el uso de valores numéricos diferenciados -discretos o discontinuos- con base en algún sistema numérico para representar un objeto, que de esta forma será un objeto digital, a diferencia de un espectro continuo de valores (como el generado por un sistema analógico) [Informática]. Véase también: "codificación analógica"; "codificación binaria", "codificación por series de bytes".

\section{CODIFICACIÓN DURADERA}

\section{durable encoding}

s. La codificación de documentos u otros objetos digitales de conformidad con estándares de amplio uso hasta niveles elementales de codificación tales como ASCII o 
UTF-8, u objetos como XML [Informática]. Véase también: "normalización", "estrategia de preservación de documentos de archivo".

\section{CODIFICACIÓN POR SERIES DE BYTES}

\section{byte-serialized encoding}

s. El proceso de convertir un objeto digital desde un estado de representación por bits a un estado de representación por bytes o caracteres [Informática]. Véase también: "codificación analógica", "codificación digital", "codificación binaria".

\section{CODIFICAR}

\section{encode}

v. Transformar la formulación de un mensaje mediante las reglas de un código [Diccionario General]. Véase también: "codificación analógica", "codificación binaria", "codificación por series de bytes", "texto cifrado", "codificación digital", "codificación duradera", "esquema de codificación de metadatos".

\section{CÓDIGO ABIERTO}

\section{open source}

a. 1. Método y filosofía para licenciamiento y distribución de programas y aplicaciones de cómputo concebido para estimular su uso y mejora en forma colaborativa y voluntaria, lo cual asegura que cualquier persona puede copiar el código fuente y modificarlo libremente. Op.: "código propietario" [Informática]. 2. Atributo de un programa o aplicación de computadora cuyo código fuente está disponible al público para uso y/o modificación de su diseño original sin restricciones (abierto). Op.: "código propietario" [Informática]. 


\section{CÓDIGO BINARIO}

binary code

s. Sistema numérico y el código derivado de él basado en dos dígitos, 1 y 0 , llamados bits (por binary digits) o dígitos binarios. Físicamente pueden estar representados por impulsos eléctricos, magnéticos, ópticos o de otro tipo [Informática]. Véase también: "codificación binaria".

\section{CÓDIGO DE CLASIFICACIÓN}

classification code

s. Una serie de símbolos alfabéticos, numéricos o alfanuméricos utilizados para identificar un documento de archivo dentro de su contexto documental [Archivos].

\section{CÓDIGO DE IMPORTANCIA VITAL}

\section{vital record code}

s. Indicación del grado o nivel de importancia de un documento de archivo para la continuidad de la actividad para la que fue producido o para la persona $u$ oficina que lo creó [Archivos].

CÓDIGO DE MÁQUINA

\section{machine code}

Véase: "lenguaje de máquina".

\section{CÓDIGO DE PRIVILEGIOS DE ACCESO}

\section{access privileges code}

s. La indicación de la persona, puesto u oficina autorizada para hacer o borrar anotaciones en un documento de archivo, o para suprimir el documento de un sistema [Archivos]. 
CÓDIGO DE RESTRICCIONES DE ACCESO

access restrictions code

s. La indicación de la persona, puesto u oficina autorizada para leer un documento de archivo en un sistema [Archivos].

CÓDIGO PROPIETARIO

\section{proprietary code}

s. Método y filosofía para licenciamiento y distribución de programas y aplicaciones de cómputo que establece su propiedad y exclusividad a un propietario; por lo mismo, nadie puede copiar o modificar el código fuente sin su consentimiento específico y, por lo general, mediante un pago. Op.: "código abierto” [Informática].

COMPATIBILIDAD

\section{compatibility}

s. La capacidad de diferentes dispositivos o sistemas -programas, formatos de archivo, protocolos, lenguajes de programación, etcétera- para trabajar juntos o intercambiar datos sin necesidad de modificación previa [Informática]. Véase también: "multiplataforma", "interoperabilidad".

\section{COMPATIBILIDAD RETROSPECTIVA}

\section{backward compatibility}

s. La capacidad de un sistema o programa de compartir datos y/o comandos con versiones anteriores del mismo, o con otros sistemas y programas a los que ha sustituido o pretende sustituir. Algunas veces esta compatibilidad se limita a la capacidad de leer datos anteriores pero no 
se extiende a la capacidad de reescribir estos datos en formatos que puedan ser leídos por versiones anteriores [Informática]. Véase también: "conversión", "estrategia de preservación de documentos de archivo", "reingeniería de software".

\section{COMPETENCIA}

\section{competence}

s. El ámbito de responsabilidad de funciones otorgado a una persona física o jurídica [Archivos].

\section{COMPILAR}

v. Reunir y juntar piezas de datos existentes o información de varias fuentes en un todo ordenado y estructurado [Diccionario General].

\section{COMPLETITUD}

\section{completeness}

s. Característica de un documento de archivo que se refiere a la presencia dentro del mismo de todos los elementos requeridos por su productor y su sistema jurídico para ser capaz de generar consecuencias. Junto con el "carácter primitivo" y la "efectividad" de un documento es una cualidad básica de un documento de archivo original [Archivos]. También se le conoce como "exhaustividad”. Véase también: Ontología A, Ontología B.

\section{COMPONENTE}

\section{component}

s. Una entrada, parte, pieza, ensamblaje o sistema que: 1) se requiere para llevar a cabo una actividad o tarea, 2) realiza una función distinguible y necesaria en la operación de un sistema o 3) debe estar incluida en un objeto 
terminado, empacado y etiquetado. Los componentes se agregan o remueven siempre como una sola unidad ya que se consideran indivisibles para un uso o propósito en particular. En archivística, por ejemplo, un componente es una parte o pieza que no constituye un documento de archivo como un todo, pero que forma parte de él: texto, imagen, marca de agua, sello de tiempo, firma electrónica y otros [Archivos].

\section{COMPONENTE ANALÓGICO}

\section{analogue component}

s. Un objeto analógico que es parte de uno o más documentos analógicos y que requiere de cierta acción de preservación [Archivos]. Véase también: "componente digital".

\section{COMPONENTE DIGITAL}

\section{digital component}

s. Cada objeto lógico que no constituye un documento de archivo en sí, pero que forma parte de uno o más documentos de archivo digitales. En él se encuentran los datos, la información técnica interna, las certificaciones y los metadatos de autenticidad necesarios para estructurar o manifestar su contenido, forma y contextos; en conjunto requieren de cierta acción de preservación. Los componentes digitales son contenidos en ficheros -archivos de computadora- y pueden manifestarse en elementos de varios tipos: texto, gráficos, imágenes fijas o móviles, sonido, aplicaciones embebidas, fuentes tipográficas, ficheros de bases de datos, ficheros asociados como hojas de estilo o CSS, bibliotecas de vínculos dinámicos o DLL, scripts, PHP, etcétera. Deben residir sobre un componente físico [Archivos]. Véase también: "componente analógico", Ontología A. 


\section{COMPONENTE DIGITAL ALMACENADO}

\section{stored digital component}

s. Un objeto digital que es guardado en un sistema de almacenamiento o en un soporte digital y es tratado como un componente digital [Archivos].

\section{COMPONENTE DIGITAL MANIFIESTO}

\section{manifested digital component}

s. Un componente digital que se recupera o genera a partir de un componente digital almacenado y que es desplegado en una forma conveniente para su visualización dentro de un documento destinado al uso de una persona ("formato legible por personas") o de una computadora ("formato legible por máquina"). También se le conoce como componente digital manifestado [Archivos].

\section{COMPONENTE FÍSICO}

\section{phisical component}

s. El soporte o medio físico en el cual están guardados o almacenados los componentes digitales de un documento de archivo. Requiere de cierta acción de conservación [Informática]. Véase también: "componente digital”.

\section{COMPONENTE INTELECTUAL}

\section{intellectual component}

s. Componente de tipo conceptual que, en conjunto, conforman un documento de archivo o alguno de sus elementos, lo identifican de forma inequívoca y lo distinguen de otros. Los componentes intelectuales son partes de concepto o de agrupación de un documento de archivo. Se distinguen seis componentes intelectuales y todos deben existir en cada documento de archivo: acciones, personas, vínculo archivístico, contenido, contextos y forma documental. De manera práctica no se encuen- 
tran agrupados así en el documento de archivo; se van a encontrar distribuidos en forma de elementos dentro de alguno de los componentes propios del documento [Archivos].

\section{COMPONER}

\section{compose}

v. Compilar, formular, generar o escribir el contenido de un documento de una manera estructurada y ordenada [Archivos].

\section{COMPRESIÓN}

\section{compression}

s. Recodificación de datos digitales para reducir sus dimensiones y poder así ahorrar espacio de almacenamiento o tiempo de transmisión [Informática]. Véase también: "compresión sin pérdida", "compresión con pérdida".

\section{COMPRESIÓN CON PÉRDIDA}

\section{lossy compression}

s. Método de compresión de archivos de datos, imágenes, sonido, etc., usado para reducir su espacio; con esta técnica se logra un factor de compresión de archivos muy alto, pero el documento descomprimido ha perdido algo de calidad con respecto al original ya que reduce la cantidad de información dentro de los datos. Op.: "compresión sin pérdida" [Informática]. Véase también: "compresión".

\section{COMPRESIÓN SIN PÉRDIDA}

\section{lossless compression}

s. Método de compresión de archivos de datos, imágenes, sonido, etcétera, usado para reducir su espacio; con esta técnica el documento descomprimido es idéntico al original 
pero el factor de compresión no es muy alto. Op.: "compresión con pérdida" [Informática]. Véase también: "compresión".

\section{CÓMPUTO DINÁMICO}

dynamic computing

s. Adaptaciones de los recursos de cómputo hechas a la medida de acuerdo a las necesidades de la organización [Archivos-Duranti \& Preston, Experiential, Interactive and Dynamic Records, p. 8].

\section{CONCLUSIÓN}

\section{conclussion}

s. Parte de la forma intelectual al final de un documento de archivo la cual contiene la suscripción o escritor, el contexto documental de la acción y la fórmula final (sin orden definido: corroboración, fecha cronológica, clausulado adicional, atestación, apreciación y certificación de firma). También se le conoce como "escatocolo" por los documentos de archivo sobre soportes tradicionales.

CONDICIONES DE CORROBORACIÓN

statement of validation

Véase: "corroboración".

CONFIABLE

trustwortby

Véase: "creíble".

CONFIANZA

trustwortbiness

Véase: "credibilidad". 
CONGELAR

freeze

v. Hacer copia inmutable de una cierta versión de un programa, aplicación o documento con objeto de establecer una cierta estabilidad en su uso [Informática-Free On-Line Dictionary of Computing (FOLDOC)].

CONJUNTO DE CARACTERES

character set

s. Un grupo de símbolos usados en computación para imprimir o desplegar en pantalla cierta información. Véase también: "American Standard Code for Information Interchange", "Universal Character Set Transformation Format 8" [Informática].

CONJUNTO DE ELEMENTOS

element set

s. Una colección de elementos los cuales tienen al menos una característica en común [Diccionario General].

\section{CONJUNTO DE ELEMENTOS DE METADATOS}

\section{metadata element set}

s. Agrupamiento de elementos de metadatos junto con sus atributos (nombre, identificador, definición de la relación con otros términos) reunidos para un propósito, comunidad o dominio específico [Diccionario General].

CONJUNTO DE METADATOS

\section{metadata set}

Véase: "conjunto de elementos de metadatos". 
CONMUTACIÓN DE PAQUETES

packet switching

s. Proceso mediante el cual los mensajes digitales son divididos en paquetes o secciones antes de ser enviados. Cada paquete es transmitido individualmente y puede seguir diferentes rutas a su destino. Una vez que todos los paquetes que forman el mensaje llegan a su destino son reconstruidos en su mensaje original [Informática].

CONSERVACIÓN DIGITAL

digital maintenance

Véase: "mantenimiento digital".

\section{CONTENIDO}

\section{content}

s. El mensaje embebido dentro del cuerpo de un documento. Deber ser estable en un documento de archivo [Archivos].

\section{CONTENIDO ESTABLE}

stable

s. Contenido de un objeto digital que sólo puede sufrir cambios obedeciendo a un conjunto de reglas fijas preestablecidas. A esta condición se le llama tener "variabilidad vinculada" [Archivos]. Véase también: "forma fija", "fijeza", "variabilidad vinculada".

\section{CONTENIDO INTELECTUAL}

\section{intellectual content}

Véase: "forma intelectual". 
CONTEXTO

context

s. El marco de referencia o entorno, ya sea físico o de situación, en el cual un documento de archivo es producido, usado o mantenido. En archivística existen cinco de ellos [Archivos].

CONTEXTO ADMINISTRATIVO

administrative context

Véase: "contexto jurídico-administrativo".

CONTEXTO DOCUMENTAL

documentary context

s. Comprende el fondo archivístico al que pertenece un documento de archivo así como su estructura interna; por ejemplo, sus cuadros de clasificación, elementos internos y externos de la forma documental, sus esquemas de metadatos, inventarios de fondos archivísticos, índices, etcétera [Archivos]. Véase también: "contexto jurídicoadministrativo", "contexto procedimental", "contexto de procedencia”, "contexto tecnológico”, Ontología A.

\section{CONTEXTO DE PROCEDENCIA}

\section{provenancial context}

s. La instancia productora de los documentos de archivo así como su mandato, estructura y funciones; por ejemplo, sus organigramas [Archivos]. Véase también: "contexto documental", "contexto jurídico-administrativo", "contexto procedimental", "contexto tecnológico", Ontología A. 
CONTEXTO JURÍDICO-ADMINISTRATIVO

juridical-administrative context

s. El sistema legal y organizacional, incluyendo la estructura, funciones y procedimientos del entorno al cual pertenece y donde actúa el cuerpo productor de los documentos de archivo [Archivos]. Véase también: "contexto documental", "contexto procedimental", "contexto de procedencia", "contexto tecnológico”, Ontología A.

\section{CONTEXTO PROCEDIMENTAL}

\section{procedural context}

s. Procedimientos y/o reglas de flujo de la organización en cuyo curso se producen documentos de archivo [Archivos]. Véase también: "contexto documental", "contexto jurídico-administrativo", "contexto de procedencia", "contexto tecnológico", Ontología A.

\section{CONTEXTO TECNOLÓGICO}

\section{technological context}

s. Características propias del equipo y programas, así como de otros componentes del o los sistemas de cómputo electrónico en el que los documentos de archivo son producidos [Archivos]. Véase también: "contexto documental", "contexto jurídico-administrativo", "contexto procedimental", "contexto de procedencia”, Ontología A.

\section{CONTINUA}

\section{continuous}

Véase: "variable continua".

\section{CONTINUO}

\section{continuum}

Véase: "continuidad de los documentos de archivo". 
CONTINUUM DE LOS DOCUMENTOS DE ARCHIVO

\section{records continuum}

Véase: "continuidad de los documentos de archivo".

\section{CONTINUIDAD DE LOS DOCUMENTOS DE ARCHIVO}

\section{records continuum}

s. Modelo usado como herramienta de integración continua por la ciencia archivística, el cual hace énfasis en características que se traslapan dentro del mantenimiento de documentos de archivo, su evidencia, transacción y la identidad del productor [Archivos]. Véase también: "ciclo de vida de los documentos de archivo".

\section{CONTROL ADMINISTRATIVO}

\section{administrative control}

s. 1. El ejercicio de cierta autoridad sobre el mantenimiento, uso, disposición y accesibilidad de archivos actuales para llevar a cabo la función para la cual fueron producidos [Archivos]. 2. Los medios para la ubicación física de los fondos de las organizaciones y centros archivísticos auxiliándose de numeración y listados topográficos. Véase también: "dependencia controladora", "custodio", "custodia", "sucesor legítimo", "productor" [Archivos].

\section{CONTROL INTELECTUAL}

\section{intellectual control}

s. El control establecido sobre el material archivístico al documentar su procedencia, arreglo, composición, alcance, contenido informacional y sus relaciones internas y externas en auxiliares de consulta [Archivos]. Véase también: "control administrativo". 


\section{CONVENCIÓN DE LLAMADA}

\section{calling convention}

s. El arreglo de argumentos (parámetros, valores o referencias) dentro de un programa o aplicación de computadora al momento de invocar un cierto procedimiento o función [Informática].

\section{CONVERSIÓN}

\section{conversion}

s. Proceso de transformación de un documento digital hacia otro objeto digital desde un formato o versión de un formato hacia otro [Archivos]. Véase también: "compatibilidad retrospectiva", "estrategia de preservación de documentos de archivo", "reingeniería de software", "migración transformativa”, "actualización”.

\section{CONVERSIÓN DE DOCUMENTOS DE ARCHIVO}

\section{conversion of records}

s. Transformación de documentos de archivo digitales de un formato o versión de formato hacia otro en el curso usual y ordinario de las operaciones propias de la organización con propósitos de seguridad, prevención de desastres, mantenimiento, modernización o reducción de la obsolescencia de la tecnología, aseguramiento de la compatibilidad con diferentes generaciones o configuraciones de equipo y programas de cómputo, o para compactar la información, dejando intacta su forma intelectual [Archivos]. Véase también: "migración de documentos de archivo", "refrescado de documentos de archivo"; "migración transformativa".

\section{CONVERTIR DOCUMENTOS DE ARCHIVO}

\section{convert records}

Véase: "conversión de documentos de archivo". 
COPIA

copy

s. También denominada "duplicado", es el resultado de un proceso de duplicación aplicado a un objeto. [Diccionario General]. Véase también: Ontología B.

\section{COPIA AUTÉNTICA}

autbentic copy

s. También llamada "copia certificada", es aquella elaborada por una persona autorizada para llevar a cabo tal función, y por tanto tiene validez legal [Archivos]. Véase también: "copia conformada", "copia en forma de original", "copia imitativa", "seudooriginal", "copia simple", Ontología B.

COPIA AUTORIZADA

autboritative copy

s. La instanciación de un documento de archivo que es considerada por su productor como su copia oficial y que por lo general ha sido sometida a controles procedimentales a los que no están sujetas otras instanciaciones [Archivos]. Véase también: "no repudio".

\section{COPIA BÁSICA}

\section{basic copy}

s. Duplicado de un objeto digital salvado en el formato de archivo en el cual fue producido originalmente o en el cual fue usado y salvado la última vez, haciéndolo por tanto inmediatamente accesible y legible en el ambiente usual de oficina de su productor [Archivos].

\section{COPIA CERTIFICADA}

\section{authentic copy}

Véase: "copia auténtica". 


\section{COPIA CONFORMADA}

\section{conformed copy}

s. Una copia exacta de un documento en la cual se han escrito explicaciones de elementos que no fueron copiados por alguna razón. Por ejemplo: la firma autógrafa de una persona que no puede ser copiada y que se pasa a la copia conformada por medio de una anotación [Archivos]. Véase también: "copia auténtica", "copia en forma de original", "copia imitativa", "seudooriginal", "copia simple", Ontología B.

\section{COPIA DE DOCUMENTO ENVIADO}

\section{copy of outgoing document}

s. Reproducción de un documento enviado a una persona o a una autoridad jurídica, la cual es apartada por su productor como documento de archivo, por lo general dentro de un sistema de mantenimiento de este tipo de documentos [Archivos]. Véase también: "documento enviado".

\section{COPIA EN FORMA DE ORIGINAL}

\section{copy in form of original}

s. Una copia idéntica al original y que tiene sus mismos efectos, pero generada posteriormente [Archivos]. Véase también: "copia auténtica", "copia conformada", "copia imitativa”, "seudooriginal”, "copia simple”, Ontología B.

\section{COPIA IMITATIVA}

\section{imitative copy}

s. Una copia que reproduce el contenido y forma de un documento de archivo, pero de manera tal que siempre es posible distinguir el original de la copia [Archivos]. Véase también: "copia auténtica", "copia conformada", "copia en forma de original", "seudooriginal", "copia simple”, Ontología B. 
COPIA OFICIAL

official copy

Véase: "copia autorizada".

COPIA SIMPLE

\section{simple copy}

s. Aquella copia que reproduce sólo el contenido de un documento de archivo y es elaborada por cualquiera [Archivos]. Véase también: "copia conformada", "copia en forma de original", "copia imitativa", "seudooriginal", “copia auténtica”, Ontología B.

\section{CORPORACIÓN}

\section{corporate body}

s. Organización o grupo de personas establecido mediante un estatuto, identificado por un nombre específico que actúa como entidad legal [Archivos].

\section{CORRECCIÓN}

\section{correct}

s. Estado de un documento de archivo cuyo contenido y forma satisfacen los requerimientos establecidos por el productor y el sistema jurídico, de tal forma que el documento de archivo alcance las consecuencias o produzca los efectos para los cuales fue concebido. Junto con la "precisión", la "veracidad" y la "pertinencia" es un componente de la "exactitud" [Diplomática].

\section{CORREO ELECTRÓNICO}

\section{e-mail}

s. Uno de los protocolos básicos de Internet, el cual permite a un usuario de computadora intercambiar mensajes y archivos de datos con otros usuarios en tiempo real, de manera local y a través de múltiples redes [Informática]. 
CORROBORACIÓN

corroboration

statement of validation

s. Uno de los elementos internos de la forma documental de un documento de archivo al final del mismo. Consiste en una fórmula o declaración explícita que enuncia las formalidades que se hacen para garantizar la autenticidad del documento, como la suscripción o firma del autor, la aposición del sello y la rogatio o ruego de suscripción del notario. En archivos digitales, se refiere a las condiciones expresamente estipuladas por su productor para que el documento de archivo sea legalmente válido [Archivos].

\section{CORRUPCIÓN}

\section{corruption}

s. Cambio en la forma, contenido o atributos de un documento de archivo de forma tal que ya no puede ser considerado como el que debía ser [Archivos].

CPU

Véase: "unidad central de proceso".

\section{CREACIÓN DE DOCUMENTOS DE ARCHIVO}

record creation

Véase: "producción de documentos de archivo".

\section{CREADOR}

\section{creator}

Véase: "productor".

\section{CREADOR DE DOCUMENTOS DE ARCHIVO}

\section{records creator}

Véase: "productor". 


\section{CREACIÓN DE DOCUMENTOS DE ARCHIVO}

\section{create record}

Véase: "producción de documentos de archivo".

\section{CREDIBILIDAD}

s. La cualidad de un documento de archivo de ser fidedigno y fehaciente cuando reúne las características de "fiabilidad", "autenticidad" y "exactitud", es decir, puede establecer, declarar o afirmar hechos; es evidente su carácter sin alteraciones ni corrupciones y su información es precisa, correcta, veraz y pertinente [Archivos].

\section{CREÍBLE}

a. Dícese de un documento de archivo que es fidedigno y fehaciente al reunir las características de "fiabilidad", "autenticidad" y "exactitud". Es decir, puede establecer, declarar o afirmar hechos; es evidente su carácter sin alteraciones ni corrupciones y su información es precisa, correcta, veraz y pertinente [Archivos].

\section{CRIPTOGRAFÍA}

\section{cryptography}

s. La práctica y estudio para proteger la información mediante su transformación (cifrar o encriptar) a una forma ilegible, llamado texto cifrado o encriptado. Sólo quien posee una llave secreta (privada) puede descifrar o desencriptar el mensaje nuevamente hacia texto plano o legible [Informática].

\section{CUADRO DE CLASIFICACIÓN}

\section{classification scheme}

s. También llamado "esquema de clasificación", permite la identificación y el arreglo sistemático de las activida- 
des operativas de una organización y de los documentos de archivo en categorías de acuerdo a convenciones, métodos y normas procedimentales estructuradas de forma lógica. En la práctica, consiste en una tabla, esquema u otra representación que categoriza los documentos de archivo del productor por clases jerárquicas y de acuerdo a un sistema de codificación expresado en símbolos alfabéticos, numéricos o alfanuméricos. En México se le conoce también como cuadro de clasificación archivística [Archivos-cadena de preservación].

\section{CUERPO}

body

s. Parte de la forma intelectual de un documento de archivo que conforma su porción principal, pues contiene la acción e incluye las consideraciones y circunstancias que le dieron origen, así como las condiciones relativas a su cumplimiento. Está conformado por uno o varios de los elementos siguientes: preámbulo, exposición, clausulado y disposiciones. También se le denomina "descripción". En documentos de archivo tradicionales es conocido como el "texto" del documento.

\section{CULTURA ORGANIZACIONAL}

\section{organizational culture}

s. Un sistema de valores, presunciones, creencias, prácticas y formas de trabajo compartidas al interior de una organización; pueden ser explícitas o implícitas en naturaleza y conforman un sistema sociocultural de interacción de las personas dentro de una organización. 


\section{CUMPLIMIENTO}

compliance

s. Proceso de asegurar que los requisitos establecidos en leyes, reglamentos, códigos industriales y estándares organizacionales se cumplan [Archivos].

\section{CUSTODIA}

\section{custody}

s. La responsabilidad básica para la tutela de los documentos de archivo o archivos basada en la posesión física de los mismos sin que necesariamente implique un título legal [Archivos]. Véase también: "control administrativo", "dependencia controladora".

\section{CUSTODIA ININTERRUMPIDA}

\section{unbroken custody}

s. Una línea ininterrumpida y documentada de cuidado, control y típicamente posesión de un cuerpo de documentos de archivo desde su producción hasta la preservación, la cual sirve como medio de protección de la autenticidad de esos documentos [Archivos]. Véase también: "cadena de preservación".

\section{CUSTODIO}

\section{custodian}

s. Persona o institución que tiene bajo su cargo la función de guardar o vigilar (una persona, propiedad, documentos $\mathrm{u}$ otros valores) [Archivos].

\section{CUSTODIO DE CONFIANZA}

\section{trusted custodian}

Véase: "custodio fiable". 


\section{CUSTODIO FIABLE}

\section{trusted custodian}

s. Un preservador que puede demostrar que no tiene razón o interés alguno para alterar los documentos de archivo preservados ni permitir que otros lo hagan; es capaz de implementar todos los requerimientos necesarios para la preservación de copias auténticas de los documentos bajo su cuidado [Archivos]. Véase también: "archivista", "administrador de documentos de archivo", "requisitos de autenticidad", "requisitos básicos de autenticidad", "requerimientos para pruebas de autenticidad", "preservador designado de documentos de archivo", "funcionario de confianza de documentos de archivo", "tercero de confianza".

\section{CUSTODIO DE DOCUMENTOS DE ARCHIVO}

records keeper

Véase: "administrador de documentos de archivo". 


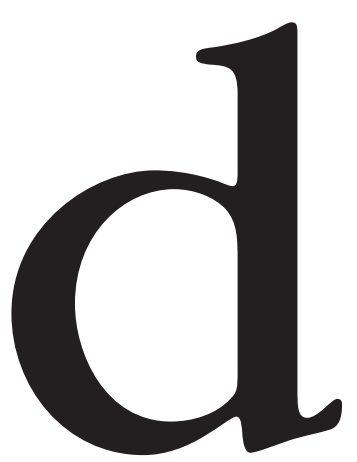

DAT

s. Acrónimo del inglés digital audio tape-"cinta de audio digital" [Informática].

DATO

data

s. La unidad más pequeña de información que tiene significado [Diccionario General]. En archivos digitales, se le considera parte de sus componentes digitales; los datos contienen la o las cadenas de bits con la información primaria del contenido del documento de archivo, en uno o varios tipos de elementos (texto, imágenes, audio, video, etcétera), que están contenidos en uno o varios objetos de información.

DATO ANALÓGICO

analogue data

s. La unidad más pequeña de información con significado, expresada en forma de señales electrónicas continuas 
o patrones mecánicos, y fijada en un medio analógico [Informática]. Véase también: "analógico", "dato digital", "documento analógico".

\section{DATO DIGITAL}

digital data

s. La mínima cantidad de información con significado, expresada en forma de dígitos -generalmente binarioscodificados de acuerdo a una convención preestablecida y fijados en un medio digital [Informática]. Véase también: "dato analógico".

\section{DECISIONES DE VALORACIÓN}

\section{appraisal decisions}

s. Determinación de los periodos de retención y disposición de los documentos de archivo de un fondo, incluyendo los términos y condiciones de transferencia de los mismos del productor hacia el preservador [Archivos]. Este término se usa en España, México, Centroamérica, Colombia y Perú; no así en Argentina, Uruguay y Brasil, donde el término "valoración" no es utilizado y en su lugar se usa "evaluación”.

\section{DECISIONES DE VALORACIÓN DOCUMENTAL}

\section{appraisal decisions}

Véase: "decisiones de valoración".

\section{DECLARACIÓN DE DOCUMENTOS DE ARCHIVO}

\section{declare records}

s. Acción de separar intelectualmente documentos producidos o recibidos por medio de la asignación de códigos de clasificación de acuerdo al esquema de clasificación, añadiendo estos códigos a los metadatos de identificación. También se emplea la asignación de números de 
registro a dicho documento y a los metadatos, basados en un esquema de registro de identificación [Archivos].

\section{DEFINICIÓN DE TIPO DE DOCUMENTO}

\section{document type definition}

s. También conocida como "DTD" por document type definition. Es la manera en que se define un cierto tipo de documento (libro, plano, mapa, documento de archivo, entre otros) en los metalenguajes SGML o XML y que consiste en una descripción detallada del documento utilizando un grupo de etiquetas de marcado, definidas expresamente para esa clase de documento. La definición de tipo de documento consiste en describir la estructura, la sintaxis, la validación y la interpretación del documento. Su función básica es mantener la consistencia entre todos los documentos que utilicen la misma DTD a través de un formato común a todos ellos [Informática]. Véase también: "esquema de un documento".

\section{DEPENDENCIA}

\section{agency}

s. Cuerpo administrativo a quien le ha sido delegada la autoridad para actuar con competencia a nombre de una entidad superior; también se le denomina agencia. Toda dependencia debe tener personalidad jurídica o estar creada por acuerdo estatutario específico, y sus titulares deben ser personas con personalidad jurídica o designación específica [Archivos]. En México por lo general aplica a una secretaría de Estado en la administración pública.

\section{DEPENDENCIA CONTROLADORA}

\section{controlling agency}

s. La dependencia encargada de ejercer el control administrativo de documentos de archivo. También denominada 
"agencia controladora" [Archivos]. Véase también: "custodia", "productor".

\section{DERECHO DE COPIA}

copyright

s. Derecho de propiedad intelectual derivado de la autoría de una obra literaria, musical, artística, fotográfica o fílmica, fijada sobre un medio tangible de expresión, y por medio del cual el titular del derecho tiene la exclusividad de reproducir, adaptar, distribuir, realizar y exhibir la obra. Esta figura proviene del derecho consuetudinario anglosajón. Su equivalente en el derecho romano-canónico es el derecho de autor [Diccionario General]. Véase también: "derechos patrimoniales".

\section{DERECHOS DE ACCESO}

\section{access rights}

Véase: "privilegios de acceso".

\section{DERECHOS DE PROPIEDAD INTELECTUAL}

\section{intellectual property rights}

s. Los derechos de individuos y organizaciones para el uso, explotación y diseminación de ideas e información; se dividen en derechos de autor (derechos morales y patrimoniales) y en derechos de propiedad industrial (marcas y patentes) [Diccionario General].

\section{DERECHOS DE PROPIEDAD INTELECTUAL DE TERCEROS}

\section{third-party intellectual property rights}

s. Derechos de propiedad intelectual que pertenecen a otra persona distinta del autor o destinatario del documento de archivo [Archivos]. 


\section{DERECHOS MORALES}

\section{moral rights}

s. Forman parte de los derechos de autor, son aquellos que el autor o productor retiene (sin importar si el autor aún retiene los derechos patrimoniales) sobre la integridad de una obra; el derecho a ser asociado con el trabajo como el nombre del autor o su seudónimo y el derecho a permanecer anónimo (derechos de atribución); el derecho a rechazar o permitir que la obra sea asociada con un producto, servicio, causa o institución de forma que pueda perjudicar el honor o la reputación del autor [Diccionario General]. Véase también: "derechos patrimoniales".

\section{DERECHOS PATRIMONIALES}

patrimonial rights

s. Son parte de los derechos de autor, consisten en los derechos de individuos y organizaciones para explotar y usufructuar económicamente una obra [Diccionario General]. Véase también: "derechos morales".

\section{DESCIFRAR}

\section{decrypt}

v. Transformar un mensaje, mediante las reglas de un código, formulación o clave, a su forma original para hacerlo inteligible. Dicho mensaje se había cifrado u ocultado transformándolo en guarismos, letras o símbolos con la intención de volverlo ininteligible a extraños y transmitirlo o almacenarlo en forma segura. Sólo el que conoce el código o clave válidos puede descifrarlo nuevamente. También se le conoce como "desencriptar". 
DESCOMPRESIÓN

decompression

s. Recuperación de una imagen o datos comprimidos a su forma original. Algunos métodos de compresión pierden información, de manera que la imagen o datos descomprimidos no son equivalentes al original [Informática]. Véase también: "compresión sin pérdida", "compresión con pérdida".

\section{DESCRIPCIÓN}

\section{description}

s. Parte de la forma intelectual de un documento de archivo la cual conforma la porción principal del mismo, ya que contiene la acción e incluye las consideraciones y circunstancias que le dieron origen así como las condiciones relativas a su cumplimiento. Está conformado por uno o varios de los elementos siguientes: preámbulo, exposición, clausulado y disposiciones. También se le llama "cuerpo" [Diplomática]. Véase también: "control administrativo", "descripción de documentos de archivo".

\section{DESCRIPCIÓN ARCHIVÍSTICA}

\section{archival description}

s. Creación de una representación precisa de una unidad de descripción archivística y en su caso de las partes que la componen, mediante la captura, análisis, organización y registro de la información que sirve para identificar, administrar, localizar y explicar los materiales archivísticos, así como el contexto y los documentos de archivo que se producen de la descripción.

\section{DESCRIPCIÓN DE ACCIÓN O MATERIA}

\section{description of action or matter}

s. Uno de los elementos internos de la forma documental que consiste en presentar la motivación de ideas (preám- 
bulo) o la razón concreta (exposición) para la acción y/o materia o asunto (disposición) expresadas en el contenido de un documento de archivo [Diplomática].

\section{DESCRIPCIÓN DE DOCUMENTOS DE ARCHIVO}

\section{describe records}

s. Identificación de documentos de archivo de un productor en cuanto a su procedencia y relaciones de acuerdo con los conceptos y principios del ordenamiento de archivos [Archivos]. Véase también: "descripción archivística", "instrumento descriptivo".

DESENCRIPTAR

decrypt

Véase: "descifrar".

\section{DESTINATARIO}

\section{addressee}

s. Persona física o jurídica a quien se dirige o para quien está previsto un documento de archivo. Véase también: Ontología A [Archivos].

DETERMINACIÓN DE LOS REQUISITOS PARA PRESENTACIÓN DE DOCUMENTOS DE ARCHIVO

determine requirements for presenting records/aggregates

s. Análisis, definición y documentación de requisitos para presentar documentos de archivo y sus agregaciones, con base en lineamientos para su organización, de tal forma que puedan satisfacer peticiones para documentos de archivo o agregaciones que reflejen todas sus interrelaciones [Archivos-Eastwood, Hofman \& Preston, Modeling Digital Records...]. 


\section{DIGITAL}

digital

a. Representación de objetos o datos físicos por medio de valores numéricos diferenciados -discretos o discontinuos-, por lo general binarios (bits), de acuerdo con un código o convención preestablecido. En contraste con una representación analógica de un objeto o proceso físico, una representación digitalmente codificada nunca se parece al original [Informática]. Véase también: "variable discreta".

\section{DIGITAL DE ORIGEN}

\section{- born digital}

s. Generado inicialmente en forma digital. Que no existió previamente en forma analógica.

\section{DIPLOMÁTICA}

diplomatics

s. Disciplina que estudia la génesis, forma y transmisión de los documentos de archivo así como sus relaciones con los hechos representados en ellos y con su productor, con objeto de identificar, valorar y comunicar su verdadera naturaleza [Archivos].

\section{DIRECCIÓN (computación)}

\section{address}

s. Lugar o ubicación donde cierto objeto de información es almacenado dentro de una computadora o donde una entidad puede ser contactada [Informática].

\section{DIRECCIÓN ELECTRÓNICA}

\section{electronic address}

s. Ubicación de un cierto dato en la memoria principal o en el disco de una computadora. Puede describirse a 
estas memorias como un arreglo de cajas de almacenamiento, cada una con un byte o carácter de capacidad. Cada caja tiene un número único -su dirección- para identificarla. Especificando una cierta dirección electrónica de memoria, los programadores pueden acceder a un cierto byte en particular. Los discos están divididos en pistas y sectores, cada uno de ellos con una dirección electrónica única [Informática].

\section{DIRECTIVA}

directive

s. Orden, disposición o instrucción, especialmente aquellas emitidas por una agencia, organización, corporación u otra autoridad central [Gobierno]. Véase también: "mejores prácticas", "lineamiento", "política”, "regla”, "estándar".

\section{DIRECTRIZ}

\section{guidelines}

Véase: "lineamiento".

\section{DISCO COMPACTO (CD)}

compact disc

s. Medio de almacenamiento digital que consiste en un disco plástico, grabado por un solo lado, capaz de almacenar cerca de 700 Megabytes de datos digitales sobre una pista espiral microscópica y continua, la cual es leída ópticamente gracias a un rayo láser. Sus especificaciones y formatos están establecidos en los estándares ISO 9660 y 13490 [Informática]. Véase también: "videodisco digital", "cinta de audio digital", "cinta digital lineal", "disco óptico". 


\section{DISCO DURO}

\section{bard disk}

bard drive

s. También se le conoce como disco rígido, es un dispositivo de almacenamiento de datos no volátil que usa un método de grabación magnética para almacenar datos digitales. Está formado por uno o varios platos o discos metálicos rígidos cubiertos con un material ferromagnético, montados sobre un eje común, que giran a gran velocidad dentro de una carcasa sellada. Sobre cada plato y en cada una de sus caras se sitúa un cabezal de lectoescritura para leer o grabar los datos [Informática]. Véase también: "almacenamiento no-volátil".

\section{DISCO ÓPTICO}

\section{optical disk}

s. Medio de almacenamiento digital consistente en un disco plástico, recubierto con una superficie brillante especial, en el cual los datos son grabados como bits ( 1 y 0 ). Los hay del tipo no reescribible o fijo, en donde el grabado se hace en forma de pequeños orificios sobre la superficie del disco sobre una pista microscópica; en el tipo reescribible el grabado se hace con reorientaciones optomagnéticas de pequeñas partes de su superficie. Ambos son leídos ópticamente gracias a un rayo láser y sus señales son decodificadas por un microprocesador hacia impulsos digitales eléctricos procesables por una computadora [Informática]. Véase también: "videodisco digital", "disco compacto", "almacenamiento no-volátil".

\section{DISCRETO}

\section{discrete}

Véase: "variable discreta". 


\section{DISPOSICIÓN}

\section{disposition}

s. 1. Destrucción final de documentos de archivo, o transferencia de éstos hacia un destino final en un archivo histórico según se ha preestablecido en su valoración y establecido en su "tabla de retención" [Archivos]. 2. Un elemento interno de la forma documental el cual comprende el núcleo del texto de cierto documento que narra la expresión de la intención del autor y la acción del documento de archivo [Diplomática] [Archivos-Duranti, Diplomatics: New Uses for an Old Science, pp. 6-24]. Véase también: Ontología A.

DISPOSICIÓN (dentro de un documento)

dispositive

s. Constitución de un acto jurídico [Archivos].

\section{DISPOSICIÓN PLANEADA}

\section{planned disposition}

Véase: "tabla de retención".

DLT

Véase: "cinta digital lineal".

\section{DOCUMENTACIÓN}

\section{documentation}

s. Todo material que sirve para describir y hacer más entendible un sistema, sin intención de contribuir a su operación. La documentación es frecuentemente clasificada de acuerdo a su propósito; así, para cierto sistema pueden existir documentos de sus requerimientos, documentos acerca de su diseño, etcétera. En contraste a la documentación orientada hacia el desarrollo y mantenimiento del sistema, la documentación del usuario 
describe aquellos aspectos del mismo que son de interés para los usuarios finales [Diccionario General].

\section{DOCUMENTACIÓN ARCHIVÍSTICA}

archival documentation

s. La información proporcionada por el productor y el repositorio que proporciona información suficiente para establecer la procedencia, historia y contexto de los documentos de archivo adquiridos y que permiten su uso por otros [Archivos].

\section{DOCUMENTO}

document

s. Unidad indivisible de información constituida por un mensaje fijado a un medio de manera sintácticamente estable. Un documento tiene por tanto siempre una forma fija y un contenido estable [Archivos-Duranti, Diplomatics: New Uses for an Old Science, p. 41].

\section{DOCUMENTO ANALÓGICO}

analogue document

s. Componente o grupo de componentes analógicos fijado sobre un medio analógico y que es tratado y manejado como un documento. Véase también: "documento digital".

DOCUMENTO ARCHIVÍSTICO

archival document

Véase: "documento de archivo".

DOCUMENTO CAPTURADO

captured document

s. Un documento digital elaborado o recibido que ha sido salvado por su productor [Archivos]. 
DOCUMENTO COMPATIBLE CON SGML

SGML-compliant document

s. Un documento digital codificado usando el "Lenguaje de Marcado Estándar Generalizado" (SGML) o cualquier otro de los lenguajes de marcado derivados de éste, como el HTML o el XML [Informática].

\section{DOCUMENTO DE ARCHIVO}

\section{record}

s. Documento elaborado o recibido por una organización durante el curso de una actividad práctica, ya sea como instrumento o derivado de esa actividad, y que es separado (apartado, guardado) para acción posterior o como referencia de que esa actividad fue realizada. También se le conoce como "documento archivístico" [Archivos]. Véase también: "documento de archivo digital", "documento de archivo activo", "documento de archivo almacenado", "documento de archivo analógico", "documento de archivo autenticado", "documento de archivo auténtico", "documento de archivo autorizado", "documento de archivo clasificado", "documento de archivo completo", "documento de archivo producido", "documento de archivo declarado" (o manifiesto), "documento de archivo efectivo", "documento de archivo fiable", "documento de archivo inactivo", "documento de archivo oficial", "documento de archivo original", "documento de archivo perfecto", "documentos de archivo adquiridos", "documentos de archivo ingresados", "documento(s) de archivo descrito(s)", Ontología A.

\section{DOCUMENTO DE ARCHIVO ACTIVO}

\section{active record}

\section{current record}

s. Un documento de archivo necesario por su productor para llevar a cabo la acción para la que el documento fue 
producido o para ser usado como referencia frecuente [Archivos]. Véase también: "documento de archivo inactivo", "ciclo de vida de los documentos de archivo", "documento de archivo semiactivo".

\section{DOCUMENTO DE ARCHIVO ADQUIRIDO}

acquired records

s. Documento de archivo del productor que es tomado en custodia por el preservador para su preservación permanente [Archivos-modelo de la cadena de preservación].

DOCUMENTO(s) DE ARCHIVO AGREGADO(s)

\section{aggregated records}

s. Una acumulación natural de un grupo interrelacionado de documentos de archivo, tales como un expediente, dossier, serie o fondo, la cual es el resultado de la manera en la que el productor de los documentos realiza sus actividades o funciones siguiendo un orden de actividad, de procedimiento o cronológico. También se le conoce como "agregación de documentos de archivo" [Archivos].

DOCUMENTO DE ARCHIVO ALMACENADO

stored digital record

s. Un documento digital almacenado que es tratado y manejado como un documento de archivo [Archivos].

DOCUMENTO DE ARCHIVO ANALÓGICO

analogue record

s. Un documento de tipo analógico que es tratado y manejado como un documento de archivo [Archivos]. Véase también: "documento de archivo digital". 


\section{DOCUMENTO DE ARCHIVO ARREGLADO}

\section{arranged records}

s. Documento de archivo de un productor que ha sido identificado por su procedencia y relaciones de acuerdo con los conceptos y principios del ordenamiento de archivos [Archivos-modelo de la cadena de preservación].

DOCUMENTO DE ARCHIVO AUDIOVISUAL

\section{audiovisual record}

s. Documento de archivo con información de imágenes visuales y auditivas, sin importar el formato [Archivos].

DOCUMENTO DE ARCHIVO AUDITIVO

aural record

s. Un documento de archivo que representa palabras, música o cualquier otra manifestación de sonido que puede percibirse solamente al escucharla [Archivos].

\section{DOCUMENTO DE ARCHIVO AUTENTICADO}

autbenticated record

s. Un documento de archivo cuya autenticidad ha sido declarada en cierto punto específico del tiempo por una persona con calidad jurídica y con autoridad para hacer tal declaración (por ejemplo, un servidor público, notario o autoridad certificadora) [Archivos]. Véase también: "documento de archivo auténtico".

\section{DOCUMENTO DE ARCHIVO AUTÉNTICO}

\section{autbentic record}

s. Documento de archivo que es lo que pretende ser y está libre de alteración o corrupción [Archivos]. Véase también: "documento de archivo autorizado", "documento 
de archivo completo", "documento de archivo efectivo", "documento de archivo perfecto", "documento de archivo fiable", "documento de archivo autenticado", Ontología B.

\section{DOCUMENTO DE ARCHIVO AUTORIZADO}

\section{autboritative record}

Véase: "documento de archivo de autoridad".

\section{DOCUMENTO DE ARCHIVO CLASIFICADO}

classified records

s. Documento de archivo, elaborado o recibido por el productor, al que se le ha asignado un código o número de clasificación basado en un cuadro o esquema de clasificación [Archivos].

\section{DOCUMENTO DE ARCHIVO COMPLETO}

complete record

s. Un documento de archivo que contiene todos los elementos requeridos tanto por el productor como por el sistema jurídico, por lo que es capaz de generar consecuencias [Archivos]. Véase también: "documento de archivo auténtico", "documento de archivo autorizado", "documento de archivo efectivo", "documento de archivo perfecto", "documento de archivo fiable", "documento de archivo autenticado", Ontología B.

\section{DOCUMENTO DE ARCHIVO CONFIABLE}

reliable record

Véase: "documento de archivo fiable".

DOCUMENTO DE ARCHIVO CREADO

created record

Véase: "documento de archivo producido". 


\section{DOCUMENTO DE ARCHIVO DE APOYO}

\section{supporting record}

s. Un documento de archivo retrospectivo que constituye evidencia escrita de una actividad que no desemboca en un acto jurídico, pero que en sí misma es jurídicamente relevante. Es una de las seis categorías funcionales de documentos de archivo junto con los documentos instructivos, habilitadores, narrativos, probatorios y dispositivos [Archivos].

\section{DOCUMENTO DE ARCHIVO DE AUTORIDAD}

\section{autboritative record}

s. Un documento de archivo considerado por su productor como documento oficial, generalmente sujeto a controles procedimentales que no son requeridos para otra clase de copias. La identificación de documentos de archivo autorizados corresponde a una oficina con responsabilidad primaria como uno de los componentes de una tabla de retención [Archivos]. También se le conoce como "documento de archivo autorizado". Véase también: "documento de archivo auténtico", "documento de archivo completo", "documento de archivo efectivo", "documento de archivo perfecto", "documento de archivo fiable", "documento de archivo autenticado", "documentos de archivo ingresados", "documento(s) de archivo descrito(s)", Ontología B.

\section{DOCUMENTO DE ARCHIVO DE INGRESO}

\section{accesion record}

s. Un documento de archivo en forma de acta que documenta la aceptación de responsabilidad para preservar un conjunto de documentos de archivo claramente identificados [Archivos]. 
DOCUMENTO DE ARCHIVO DE PROGRAMA

Véase: "documento de archivo operacional".

DOCUMENTO DE ARCHIVO DECLARADO

declared record

manifested record

s. También llamado "documento de archivo manifiesto". Un documento de archivo identificado, elaborado o recibido por el productor, al cual se le ha asignado un código de clasificación basado en el cuadro de clasificación y que ha sido registrado de acuerdo a un esquema de registro [Archivos].

DOCUMENTO(s) DE ARCHIVO DESCRITO(s)

described record

s. Conjunto ordenado de documentos de archivo arreglados; esto es, les ha sido extraída y registrada la información acerca de su naturaleza, aspecto y contextos (jurídico-administrativo, de procedencia, procedimental, documental y tecnológico) con fines de facilitar su control administrativo e intelectual [Archivos]. Véase también: "descripción archivística", "instrumento descriptivo".

DOCUMENTO DE ARCHIVO DIGITAL

\section{digital record}

s. Un documento de archivo es un documento producido (elaborado o recibido, y guardado -separado, apartadopara acción posterior y referencia) por una persona física o jurídica en el curso de una actividad práctica como instrumento o subproducto de tal actividad. Cuando el documento de archivo es guardado y utilizado en forma digital entonces es un documento de archivo digital, independientemente de la forma original en la que ha- 
ya sido elaborado o recibido. [Archivos]. Véase también: "documento de archivo analógico".

DOCUMENTO DE ARCHIVO DIGITAL ALMACENADO

stored digital record

s. Un documento de archivo digital que se encuentra almacenado y que es tratado y manejado como un documento de archivo [Archivos].

DOCUMENTO DE ARCHIVO DIGITAL MANIFIESTO manifested digital record

s. Un documento de archivo digital que es tratado y manejado como un documento de archivo. También se le denomina "documento de archivo digital presentado" [Archivos]. Véase también: "documento de archivo digital reproducido".

DOCUMENTO DE ARCHIVO DIGITAL PRESENTADO

presented digital record

Véase: "documento de archivo digital manifiesto".

DOCUMENTO DE ARCHIVO DIGITAL REPRODUCIBLE reproducible digital record

s. Los componentes digitales de un documento de archivo junto con la información técnica o los programas necesarios para reproducirlo y manifestarlo a partir de esos componentes digitales [Archivos].

\section{DOCUMENTO DE ARCHIVO DIGITAL REPRODUCIDO}

\section{reproduced digital record}

$\mathrm{s}$. Una representación auténtica u otra versión de un documento de archivo reconstituido a partir de sus componentes digitales [Archivos]. Véase también: "documento 
de archivo auténtico", "copia en forma de original", "copia imitativa", "documento de archivo digital manifiesto", "copia simple".

\section{DOCUMENTO DE ARCHIVO DINÁMICO}

dynamic record

s. Un documento de archivo cuyo contenido depende de datos que pueden tener instanciaciones variables, las cuales pueden estar almacenadas en bases de datos y hojas de cálculo internas o externas al sistema en donde el documento de archivo es generado [Archivos]. Véase también: "documento de archivo experiencial", "documento de archivo interactivo".

\section{DOCUMENTO DE ARCHIVO DISPOSITIVO}

\section{dispositive record}

s. Un documento de archivo retrospectivo que tiene el propósito de poner en existencia un acto cuyos efectos están definidos por el escrito en sí mismo; es decir, la forma escrita del documento de archivo es la esencia y sustancia del acto. Es una de las seis categorías funcionales de documentos de archivo junto con los documentos instructivos, habilitadores, narrativos, probatorios y de apoyo [Archivos].

\section{DOCUMENTO DE ARCHIVO EFECTIVO}

\section{effective record}

s. Un documento de archivo capaz de lograr las consecuencias o producir los efectos para los que fue concebido [Archivos]. Véase también: "documento de archivo auténtico", "documento de archivo autorizado", "documento de archivo completo", "documento de archivo perfecto", "documento de archivo fiable", Ontología B. 


\section{DOCUMENTO DE ARCHIVO EJECUTADO}

\section{executed record}

s. Un documento de archivo que ha participado en la fase de ejecución de un procedimiento administrativo, $\mathrm{y}$ al que se le han agregado metadatos pertinentes que expresan las acciones tomadas durante el curso del procedimiento, tales como prioridad y fecha de transmisión, hora y/o lugar, acciones tomadas, número de transacción, etcétera [Archivos].

\section{DOCUMENTO DE ARCHIVO ELABORADO}

\section{made record}

s. Un documento compuesto o compilado por el productor y declarado como documento de archivo; por tanto, apartado o separado para acción o referencia, generalmente dentro de un sistema de mantenimiento de documentos de archivo [Archivos]. Véase también: "documento de archivo producido", "documento de archivo interno", "documento de archivo recibido", "producción de documentos de archivo", "mantenimiento de documentos de archivo".

\section{DOCUMENTO DE ARCHIVO ELECTROACÚSTICO}

\section{electroacustic record}

s. Un documento de archivo audible generado por un dispositivo electrónico [Archivos].

\section{DOCUMENTO DE ARCHIVO ELECTRÓNICO}

\section{electronic record}

s. Un documento de archivo analógico o digital consistente en un mensaje elaborado con base en impulsos electrónicos y que puede ser almacenado en un dispositivo al efecto, transmitido a través de un canal o red y reconstruido a lenguaje natural o forma original por 
medio de un equipo electrónico, el cual es indispensable para poder hacer inteligible el documento de nuevo [Archivos].

DOCUMENTO DE ARCHIVO ENTRANTE

\section{incoming record}

Véase: "documento de archivo recibido".

\section{DOCUMENTO DE ARCHIVO ENVIADO}

Véase: "documento enviado".

DOCUMENTO DE ARCHIVO ESCRITO

written record

s. Un documento de archivo producido por una persona física o jurídica durante el curso de una actividad práctica sobre un medio o soporte (papel, magnético, cinta, disco, etcétera) por medio de un instrumento o dispositivo escriptorio de texto, voz o imágenes [Archivos-Duranti, Diplomatics: New Uses for an Old Science].

DOCUMENTO DE ARCHIVO EXPERIENCIAL

experiential record

s. Un documento de archivo producido, usado y mantenido en un sistema experiencial [Archivos-Duranti \& Thibodeau, "The Concept of Record in Interactive, Experiential and Dynamic Environments: the View of InterPARES"]. Véase también: "documento de archivo dinámico", "documento de archivo interactivo".

\section{DOCUMENTO DE ARCHIVO FIABLE}

reliable record

s. Un documento de archivo capaz de sostener o testificar los hechos que consigna. También se le denomina "documento de archivo confiable" [Archivos]. Véase tam- 
bién: "documento de archivo auténtico", "documento de archivo autorizado", "documento de archivo completo", "documento de archivo efectivo", "documento de archivo perfecto” y Ontología B.

\section{DOCUMENTO DE ARCHIVO GENUINO}

genuine record

s. Un documento de archivo que tiene carácter real; esto es, no está falsificado, imitado o adulterado, y tiene un origen definido de una cierta fuente conocida [Archivos].

\section{DOCUMENTO DE ARCHIVO GRÁFICO}

\section{graphic record}

s. Un documento de archivo que representa un objeto por medio de dibujo o pintura, o que describe una figura, plan o boceto por medio de trazos o líneas [ArchivosInterPARES, “Template for Analysis"].

\section{DOCUMENTO DE ARCHIVO HABILITADOR}

\section{enabling record}

s. Un documento de archivo prospectivo codificado en lenguaje de máquina que está activamente involucrado en llevar a cabo una acción o proceso. Es una de las seis categorías funcionales de documentos de archivo junto con los documentos dispositivos, instructivos, narrativos, probatorios y de apoyo [Archivos].

\section{DOCUMENTO DE ARCHIVO INACTIVO}

\section{inactive record}

\section{non-current record}

s. Un documento de archivo que ya no es utilizado en el día a día de las operaciones de una organización, pero que puede guardarse para ser usado ocasionalmente con fines legales, operacionales o históricos [Archivos]. Véase 
también: "documento de archivo activo", "ciclo de vida de los documentos de archivo", "documento de archivo semiactivo".

\section{DOCUMENTO DE ARCHIVO INGRESADO}

\section{accessioned records}

s. Documento de archivo cuya autenticidad y viabilidad de preservación han sido confirmados y han sido recibidos e ingresados a un archivo histórico por un preservador, consignando este hecho en un documento de archivo de ingreso [Archivos]. Véase también: "acta de ingreso".

\section{DOCUMENTO DE ARCHIVO INSTRUCTIVO}

\section{instructive record}

s. Un documento de archivo prospectivo que contiene instrucciones acerca de acciones o procesos a ejecutar. Es una de las seis categorías funcionales de documentos de archivo junto con los documentos dispositivos, habilitadores, narrativos, probatorios y de apoyo [Archivos].

\section{DOCUMENTO DE ARCHIVO INTACTO}

\section{intact record}

s. Un documento de archivo al cual no se le ha removido o destruido ninguna parte relevante [Archivos].

\section{DOCUMENTO DE ARCHIVO INTERACTIVO}

\section{interactive record}

s. Un documento de archivo con contenido variable o forma dependiente de la entrada que proporcione el usuario y que a menudo está basada en contenido anterior. Véase también: "documento de archivo dinámico", "documento de archivo experiencial" [Archivos-Duranti \& Thibodeau, "The Concept of Record in Interactive, Experiential and Dynamic Environments: the View of InterPARES”, pp. 13-14]. 


\section{DOCUMENTO DE ARCHIVO INTERNO}

internal record

s. Un documento de archivo que es transmitido a lo largo de tiempo y espacio sólo dentro de la organización que lo produce, sin llegar a un tercero externo; por ejemplo, reportes y memorandos [Archivos]. Véase también: "documento de archivo producido", "documento de archivo elaborado", "documento de archivo recibido".

DOCUMENTO DE ARCHIVO MANIFIESTO

Véase: "documento de archivo declarado".

\section{DOCUMENTO DE ARCHIVO NARRATIVO}

\section{narrative record}

s. Un documento de archivo retrospectivo que constituye evidencia escrita de actividades sin relevancia jurídica. Es una de las seis categorías funcionales de documentos de archivo junto con los documentos dispositivos, habilitadores, instructivos, probatorios y de apoyo [Archivos].

\section{DOCUMENTO DE ARCHIVO OBSOLETO}

\section{obsolete record}

s. Un documento de archivo que ya no está en uso o ya no es útil a su productor para acción o referencia o que ya no se encuentra físicamente accesible [Archivos]. Véase también: "documento de archivo inactivo".

\section{DOCUMENTO DE ARCHIVO OFICIAL}

\section{official record}

s. Versión o instanciación completa, final y autorizada de un documento de archivo [Archivos]. Véase también: "documento de archivo autorizado". 


\section{DOCUMENTO DE ARCHIVO OPERACIONAL}

\section{operational record}

s. Un documento de archivo que está relacionado con las actividades sustantivas que una cierta organización realiza para llevar a cabo su misión o mandato. También se le conoce como "documento de archivo de programa" [Archivos-Society of American Archivists, A Glossary of Archival \& Records Terminology].

\section{DOCUMENTO DE ARCHIVO ORIGINAL}

\section{original record}

s. La primera copia o arquetipo de un documento de archivo, de la cual otros instrumentos son transcritos, copiados o iniciados [Archivos]. Véase también: Ontología B.

\section{DOCUMENTO DE ARCHIVO PERFECTO}

\section{perfect record}

s. Un documento de archivo que es capaz de producir las consecuencias deseadas por su autor; la perfección es algo que se confiere al documento de archivo debido a su forma [Archivos]. Véase también: "documento de archivo auténtico", "documento de archivo autorizado", "documento de archivo efectivo", "documento de archivo completo", "documento de archivo fiable”, Ontología B.

\section{DOCUMENTO DE ARCHIVO POTENCIAL}

\section{potential record}

s. Un documento que puede convertirse en documento de archivo. Si el productor lo trata como un documento de archivo, lo asocia con otras entidades que son indudablemente documentos de archivo, y ello sucede en el transcurso de una actividad y para propósitos de la organización, tal documento sólo requiere de una forma fi- 
ja y de un contenido estable para materializarse como un "documento de archivo completo" [Archivos- Duranti \& Thibodeau, "The Concept of Record in Interactive, Experiential and Dynamic Environments: the View of InterPARES”, p. 26].

\section{DOCUMENTO DE ARCHIVO PRESERVADO}

\section{preserved record}

s. Un documento de archivo que está dentro del sistema de preservación de documentos de archivo y que es resultado de una correcta práctica de producción, mantenimiento y preservación permanente, y que está disponible para su uso bajo demanda [Archivos].

DOCUMENTO DE ARCHIVO PROBATIVO

Véase: "documento de archivo probatorio".

\section{DOCUMENTO DE ARCHIVO PROBATORIO}

\section{probative record}

s. También llamado "documento de archivo probativo". Un documento de archivo retrospectivo del cual un sistema jurídico requiere una forma escrita como evidencia de una acción que existió y se completó antes de ser expresada por escrito. Es una de las seis categorías funcionales de documentos de archivo junto con los documentos dispositivos, habilitadores, narrativos, instructivos y de apoyo [Archivos-Duranti, Diplomatics: New Uses for an Old Science, p. 65].

\section{DOCUMENTO DE ARCHIVO PRODUCIDO}

\section{created record}

s. Un documento recibido o elaborado que ha sido declarado documento de archivo y apartado (guardado o separado) para futura acción o referencia, usualmente en 
un sistema de documentos de archivo [Archivos]. Véase también: "producción de documentos de archivo", "elaboración de documentos de archivo".

\section{DOCUMENTO DE ARCHIVO PROSPECTIVO}

\section{prospective record}

s. Un documento de archivo que da guía acerca de acciones y/o procesos a ejecutar. El documento de archivo prospectivo se divide en "documento de archivo habilitador", cuando informa qué hacer y cómo hacerlo, y en "documento de archivo instructivo", cuando informa acerca de interacciones, experiencias o procesos dinámicos [Archivos]. Véase también: "documento de archivo retrospectivo".

\section{DOCUMENTO DE ARCHIVO RECIBIDO}

received record

s. Un documento recibido que ha sido declarado documento de archivo y apartado (guardado o separado) para futura acción o referencia, usualmente en un sistema de mantenimiento de documentos de archivo [Archivos]. Véase también: "documento de archivo interno", "documento de archivo elaborado".

\section{DOCUMENTO DE ARCHIVO REGISTRADO}

registered record

s. Un documento de archivo al que le ha sido asignado un número de identificación único por lo que todos los datos necesarios para identificar a las personas y actos involucrados en él, así como el contexto documental, son grabados de acuerdo con un registro protocolario [Archivos]. 


\section{DOCUMENTO DE ARCHIVO RETROSPECTIVO}

retrospective record

s. Un documento de archivo que es útil para recordar algo que fue hecho [Archivos]. Véase también: "documento de archivo narrativo", "documento de archivo probatorio", "documento de archivo de apoyo", "documento de archivo prospectivo".

\section{DOCUMENTO DE ARCHIVO SEMIACTIVO}

semiactive record

s. Un documento de archivo que ya no es utilizado con el propósito de llevar a cabo la acción para la que fue producido, pero que sigue siendo necesario por su productor como referencia o porque su vigencia documental no ha prescrito. También se le conoce como "documento de archivo semiactual" [Archivos]. Véase también: "documento de archivo activo", "ciclo de vida de los documentos de archivo", "documento de archivo inactivo".

\section{DOCUMENTO DE ARCHIVO SEMIACTUAL}

semicurrent record

Véase: "documento de archivo semiactivo".

DOCUMENTO DE ARCHIVO VIRTUAL

virtual record

s. Un documento digital percibido como existente por un usuario, pero que en realidad no existe dentro del sistema [Archivos- Society of American Archivists, A Glossary of Archival \& Records Terminology].

\section{DOCUMENTO DE ENTRADA}

- incoming record

Véase: "documento de archivo recibido". 
DOCUMENTO DIGITAL

digital document

s. Un componente o grupo de componentes digitales que son salvados, tratados y manejados como un documento [Archivos]. Véase también: "documento analógico", "documento de archivo analógico".

\section{DOCUMENTO DIGITAL ALMACENADO}

stored digital document

s. Un documento digital, guardado en un sistema de almacenamiento y sobre un soporte digital, que es tratado y manejado como un documento [Archivos].

DOCUMENTO DIGITAL MANIFIESTO manifested digital document

s. Un documento digital que es tratado como un documento de archivo [Archivos].

\section{DOCUMENTO ELABORADO}

\section{made document}

s. Un documento compuesto o compilado por el productor [Archivos]. Véase también: "documento recibido".

DOCUMENTO ENTRANTE

incoming document

Véase: "documento recibido".

\section{DOCUMENTO ENVIADO}

outgoing document

s. Un documento que es transmitido a una persona física o jurídica en el transcurso de las actividades del productor de documentos de archivo y del cual una copia o un documento de archivo es apartado por el productor, usualmente en un sistema de mantenimiento de docu- 
mentos de archivo [Archivos]. Véase también: "copia de documento enviado".

DOCUMENTO HTML

\section{HTML document}

s. Un documento que cumple el estándar HTML con el propósito de ser publicado en la web, siendo accesible y desplegable por navegadores (browsers) como Firefox, Explorer, Safari, Chrome y Opera, entre otros [Informática]. Véase también: "HTML", "documento XML", "documento SGML".

DOCUMENTO IDENTIFICADO

\section{identified document}

s. Un documento elaborado o recibido al cual le han sido adjuntados metadatos de identidad (personas, acciones, fechas de compilación, etcétera) [Archivos].

\section{DOCUMENTO INTERNO}

- internal document

s. Un documento que es transmitido a lo largo de tiempo y espacio sólo dentro de la organización que lo produce, sin llegar a un tercero externo [Archivos].

\section{DOCUMENTO RECIBIDO}

received document

s. Un documento transmitido a un productor por parte de una persona física o jurídica externa [Archivos]. Véase también: "documento elaborado", "documento de archivo recibido".

DOCUMENTO SALIENTE

Véase: "documento enviado". 


\section{DOCUMENTO SGML}

\section{SGML document}

s. Un documento que cumple con el estándar SGML y que ha sido registrado utilizando ciertas reglas sintácticas descritas en una "definición de tipo de documento" (DTD) o en un esquema a propósito [Informática]. Véase también: "SGML", "documento XML", “documento HTML".

\section{DOCUMENTO XML}

\section{- XML document}

s. Un documento que cumple con el estándar SGML y que ha sido registrado utilizando las reglas de XML ("Lenguaje de Marcado Extendido") de acuerdo a ciertas reglas sintácticas descritas en una "definición de tipo de documento" (DTD) o en un esquema a propósito [Informática]. Véase también: "documento HTML", "documento SGML".

\section{DOMINIO}

\section{domain}

s. Un cierto campo del conocimiento o área temática que se usa dentro de una ontología, que es la formulación de un vocabulario específico para describir el conocimiento común acerca de una cierta realidad en un área temática dada. En la terminología del medio se acostumbra llamar dominio al área temática o campo del conocimiento que se pretende definir en esa ontología.

\section{DOSSIER}

\section{dossier}

s. La suma o conjunto integrado de documentos de archivo que participan en el mismo asunto o están relacionados con un mismo evento, persona, lugar, proyecto o materia. Es más conocido como "expediente" [Archivos]. Véase también: "ítem", "serie", "fondo". 


\section{DRAM}

s. Iniciales de Dynamic Random-Access Memory o memoria de acceso aleatorio dinámico. Es el tipo de memoria RAM más usado y va siempre asociado al procesador de una computadora; se compone de microtransistores y microcondensadores que han de ser actualizados cada pocos milisegundos mediante la corriente eléctrica para que permanezcan los datos e instrucciones en tránsito [Informática].

DTD

Véase: "definición de tipo de documento".

DUPLICADO

duplicate

Véase: "copia".

DVD

\section{DVD}

s. Acrónimo de digital videodisc o digital versatile disc [Informática]. 


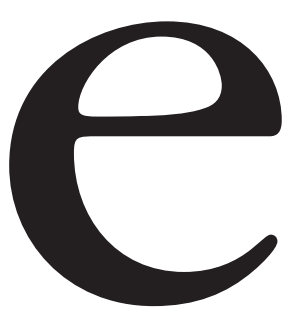

E-ADMINISTRACIÓN

e-government

Véase: "e-gobierno".

E-DESCUBRIMIENTO

electronic discovery

e-discovery

Véase: "e-hallazgo".

E-GOBIERNO

e-government

s. El uso de Tecnologías de la Información y la Comunicación (TIC) (en especial Internet) en la administración pública para mejorar o potenciar los servicios gubernamentales con los ciudadanos, empresas, industria y otras áreas de gobierno, simplificando procesos, integrándolos 


\section{E- hallazgo}

y evitando redundancias [Diccionario General]. En España se le conoce como "e-administración"; en otros países como "administración electrónica".

\section{E-HALLAZGO}

\section{electronic discovery}

s. El proceso de recolectar, preparar, revisar y producir información almacenada electrónicamente en el contexto de un proceso legal para fines de evidencia. También se le conoce como "e-descubrimiento" o "exhibición de pruebas electrónicas”. En el derecho anglosajón se le conoce también como "proposición de prueba".

\section{EFECTIVIDAD}

\section{effectiveness}

s. La característica que tiene un documento de archivo de contener todos aquellos elementos que han sido requeridos por el productor y el sistema jurídico para que el documento de archivo pueda tener las consecuencias o produzca los efectos para los que fue producido originalmente. Junto con "carácter primitivo" y "completitud" es una cualidad básica de un documento de archivo original [Archivos]. Véase también: Ontología B.

\section{ELABORACIÓN DE DOCUMENTOS DE ARCHIVO}

\section{record-making}

s. El conjunto de principios, políticas, reglas y estrategias que controlan el proceso de formación y producción de documentos de archivo a partir de documentos elaborados o recibidos [Archivos]. Véase también: "documento de archivo producido", "producción de documentos de archivo" "mantenimiento de documentos de archivo". 


\section{ELECTROACÚSTICA}

- electroacustics

s. Estudio de la captación y reproducción de los sonidos mediante aparatos eléctricos [Diccionario General].

\section{ELECTRONIC RECORDS MANAGEMENT SYSTEM}

Véase: "sistema de gestión de documentos de archivo".

\section{ELECTRÓNICA}

\section{- electronics}

s. La tecnología y los dispositivos asociados con el empleo de pequeñas corrientes eléctricas a través de circuitos o componentes de estado sólido, usados por lo general para procesamiento o transmisión de datos analógicos o digitales [Informática].

\section{ELEMENTO}

element

s. Constituyente elemental, fundamental o irreductible de una entidad compuesta [Diccionario General]. Véase también: "elemento de dato", "elemento de documento de archivo", "elemento de forma", "conjunto de elementos", "elemento interno", "elemento externo", "elemento de metadato".

\section{ELEMENTO DE DATO}

\section{data element}

s. Una unidad de datos cuya definición, identificación, representación y valores permisibles son especificados por medio de un grupo de atributos [Informática]. Véase también: "campo". 


\section{ELEMENTO DE DOCUMENTO DE ARCHIVO}

\section{record element}

s. Parte constitutiva de la forma documental de un documento de archivo; un elemento es una expresión visible sobre un documento de archivo, como una firma o un sello [Diplomática] [Archivos].

\section{ELEMENTO DE FORMA}

element of form

s. Parte constitutiva de la forma documental de un documento de archivo, visible en su superficie. Puede ser externo como un sello o interno como una inscripción. También se le denomina elemento formal [Archivos].

\section{ELEMENTO DE METADATO}

\section{metadata element}

s. Un componente básico dentro de un conjunto de metadatos [Diccionario General].

\section{ELEMENTO EXTERNO}

\section{extrinsic element}

s. Un elemento de la forma documental de un documento de archivo que forma parte de su apariencia externa. Entre los tipos de elementos externos se encuentran rasgos de presentación documental como imágenes, gráficos, diseños, hipervínculos, firmas electrónicas, sellos electrónicos, marcas de agua electrónicas, sellos digitales de tiempo emitidos por un "tercero de confianza" y signos especiales. También se le conoce como "elemento extrínseco" [Diplomática]. Véase también: "elemento interno", Ontología A. 
ELEMENTO EXTRÍNSECO

\section{extrinsic element}

Véase: "elemento externo".

\section{ELEMENTO INTERNO}

\section{intrinsic element}

s. Un elemento de la forma documental de un documento de archivo que constituye parte de su composición interna y que expresa tanto la acción en la cual participa el documento de archivo como su contenido y contexto inmediato. Estos elementos comprenden los nombres de las personas involucradas en la producción del documento de archivo, las fechas relevantes, el lugar de origen, el asunto, su atestación y la cláusula de corroboración. También se le conoce como "elemento intrínseco" [Diplomática]. Véase también: "elemento externo", Ontología A.

\section{ELEMENTO INTRÍNSECO}

\section{intrinsic element}

Véase: "elemento interno".

E-MAIL

Véase: "correo electrónico".

\section{EMULACIÓN}

\section{emulation}

s. La reproducción del comportamiento y resultados de programas y equipos de cómputo obsoletos por medio del desarrollo de nuevos programas y equipos que permiten la ejecución de aquéllos en computadoras actuales [Informática]. Véase también: "encapsulado", "estrategia de preservación de documentos de archivo", "envoltura". 


\section{EMULACIÓN PARA PRESERVACIÓN}

- preservation emulation

Véase: "emulación".

ENCAPSULADO

\section{encapsulation}

s. El proceso de ligar y guardar un documento de archivo digital u otros objetos digitales con los medios para proveer acceso a ellos, por lo general a través del uso de una "envoltura" (wrapper), de tal forma que todo queda descrito en una forma entendible para una amplia variedad de tecnologías, como un documento XML, por ejemplo [Informática]. Véase también: "emulación", "estrategia de preservación de documentos de archivo".

ENCRIPTADO

\section{encoding}

Véase: "codificación críptica".

ENCRIPTADO UTILIZANDO LLAVE PÚBLICA

public key encryption

Véase: "cifrado utilizando llave pública".

\section{ENCRIPTAR}

encode

v. Se denomina así en algunos países americanos al proceso de cifrar un mensaje para hacerlo ininteligible. Op.: "descifrar" o "desencriptar".

\section{ENTIDAD}

\section{entity}

s. Una estructura real o abstracta [Archivos-Duranti, Eastwood \& Macneil, Preservation of the Integrity of Electronic Records, p. 159]. Véase también: “objeto". 


\section{ENTIDAD DIGITAL}

\section{digital entity}

s. Una estructura digital real o abstracta [Archivos]. Véase también: "objeto digital".

ENVOLTURA

\section{wrapper}

s. Una estructura o programa que encapsula o contiene un grupo de datos con propósito de facilitar su compatibilidad, uso, transmisión y almacenamiento [Informática]. Véase también: "emulación”, "encapsulado".

ERMS

Véase: "sistema de gestión de documentos de archivo".

ESCATOCOLO

\section{eschatocol}

s. Parte final de un documento que contiene el contexto documental de la acción y la fórmula final (corroboración, fecha, clausulado adicional, atestación, certificación de firma, notas secretariales, en cualquier orden) [Archivos-Duranti, Diplomatics: New Uses for an Old Science, p. 142]. Véase también: "conclusión".

\section{ESCRITO}

\section{script}

s. Uno de los elementos externos de la forma documental, comprende todas las características de la manera de escribir un documento tales como la distribución y disposición del texto dentro del soporte físico, la caligrafía, la presencia de uno o más escribanos, la división de párrafos y la concordancia entre éstos y otras secciones conceptuales del documento, la puntuación, abreviaturas, iniciales, tinta o tipo de máquina, enmendaduras, 
correcciones, fórmulas, etcétera [Archivos-Duranti, Diplomatics: New Uses for an Old Science, p. 136]. Véase también: Ontología A.

\section{ESCRITOR}

\section{writer}

s. Una de las cinco personas que requiere un documento de archivo digital. Es la persona física o puesto responsable de articular el contenido del documento de archivo. Puede ser el autor $\mathrm{u}$ otra persona diferente, y encontrarse en la introducción, protocolo o también en la conclusión o "escatocolo" [Archivos]. Véase también: Ontología A.

\section{ESCRITURA}

\section{script}

s. Parte de la forma física de un documento de archivo; contiene el arreglo espacial y visual de los elementos de escritura del documento de archivo (disposición espacial, paginación, fuente y tipo de letra, división en párrafos, puntuación, abreviaturas, iniciales).

\section{ESPACIO DE NOMBRES}

\section{namespace}

s. Un conjunto de nombres que es usado para denominar tipos de elementos y nombres de atributos y en el cual, cuando se reúnen objetos de diferentes orígenes que tienen nombres iguales, se procede a eliminar ambigüedades ya que éstas no deben existir; esto se logra añadiendo el URL $u$ otro origen del objeto a su nombre [Archivos].

\section{ESPACIO DE NOMBRES LÓGICO}

\section{logical namespace}

Véase: "espacio de nombres". 
ESPECIFICACIÓN

specification

s. Descripción detallada de las características y/o funciones de diseño y construcción de una entidad o sistema [Informática].

\section{ESQUEMA}

\section{scheme}

s. Marco o plan estructurado conformado por un grupo de elementos independientes pero interrelacionados que constituyen un todo unificado [Diccionario General].

\section{ESQUEMA DE CLASIFICACIÓN}

\section{classification scbeme}

Véase: "cuadro de clasificación".

\section{ESQUEMA DE CODIFICACIÓN DE METADATOS}

\section{metadata encoding scheme}

s. Vocabulario controlado para valores de elementos de metadatos así como sus estructuras de codificación. Proporciona información contextual o reglas de análisis útiles en la interpretación del valor de un término. Esa información contextual puede tomar la forma de vocabularios controlados, notaciones formales o reglas de análisis. Existen dos tipos de esquemas de codificación: esquemas de codificación de vocabulario (en donde el valor del elemento se toma de un vocabulario controlado) y esquemas de codificación de sintaxis (en donde el valor de una cadena de información se formatea de acuerdo con una notación formal) [Informática]. 
ESQUEMA DE DESCRIPCIÓN DE RECURSOS

resource description framework

s. (RDF) Una estructura basada en XML para representar información acerca de recursos existentes en la web. Se usa en particular para representar metadatos acerca de recursos web tales como autor, título o fecha de modificación de páginas web, así como información acerca de derechos de propiedad intelectual y licenciamiento [Informática].

\section{ESQUEMA DE METADATOS}

\section{metadata schema}

s. Un marco de referencia que especifica y describe un conjunto estándar de elementos de metadato así como las interrelaciones entre ellos que necesitan ser registradas para asegurar la identificación de los documentos de archivo y su autenticidad. Los esquemas proveen de una sintaxis formal (estructura) y de una semántica (definiciones) para los elementos de metadato [Archivos].

ESQUEMA DE METADATOS DE ELABORACIÓN

DE DOCUMENTOS DE ARCHIVO

\section{record-making metadata schema}

s. Lista de todos los metadatos necesarios para la elaboración de documentos de archivo y que serán registrados para asegurar la "fiabilidad", la "exactitud", la identificación y la integridad de los documentos generados en el sistema de elaboración de documentos de archivo [Archivos -cadena de preservación].

\section{ESQUEMA DE METADATOS DE MANTENIMIENTO}

\section{recordkeeping metadata scheme}

s. Lista de todos los metadatos que deben ser registrados en el sistema de mantenimiento de documentos de 
archivo para asegurar la correcta identificación y la continua identidad e integridad de todos los documentos de archivo guardados en ese sistema [Archivos].

\section{ESQUEMA DE UN DOCUMENTO}

schema document

document schema

s. Un documento que cumple con las especificaciones de los metalenguajes SGML o XML y que define la estructura, contenidos y restricciones de otros documentos que a su vez cumplen con esos metalenguajes, de manera similar a una definición de tipo de documento o DTD de XML [Informática].

\section{ESQUEMA PARA REGISTRO}

\section{registration schema}

registration system

s. Método para asignar un identificador único a cada documento de archivo producido, vinculado a sus metadatos de identidad e integridad [Archivos-cadena de preservación].

\section{ESQUEMA SEMÁNTICO}

\section{semantic schema}

s. La representación de un vocabulario en una forma particular procesable por máquina, como RDF o un esquema de base de datos relacional [Informática].

\section{ESTABLE}

\section{stable}

a. Calidad relativa al contenido de un documento, el cual puede o no ser cambiado de acuerdo sólo a reglas fijas preestablecidas; es decir, está dotado de variabilidad 
vinculada (acotada, limitada) [Archivos]. Véase también: "forma fija", "fijeza".

\section{ESTÁNDAR}

\section{standard}

s. Un conjunto de regulaciones establecidas orientadas a establecer las características y especificaciones de un producto, objeto, proceso o servicio de manera uniforme, dentro de un ambiente, sector, sistema, país o a nivel mundial [Archivos]. Véase también: "mejores prácticas", "estándar de facto", "estándar de jure", "directiva”, "lineamiento", "política”, "protocolo”, "regla”.

\section{ESTÁNDAR DE FACTO}

de facto standard

s. Un estándar que no ha sido emitido por ningún organismo oficial dedicado a ello y que ha sido impuesto por el uso y aceptación generalizados por una comunidad [Diccionario General]. Véase también: "estándar de jure".

ESTÁNDAR DE JURE (o de iure)

- de jure standard

s. Un estándar emitido por algún organismo dedicado y/o autorizado para su emisión. Pueden ser nacionales (como NOM, ANSI), multinacionales (como CEN) o internacionales (como ISO) [Diccionario General]. Véase también: "estándar de facto".

\section{ESTADO DE TRANSMISIÓN}

\section{state of transmission}

Véase: "estatus de transmisión". 
ESTATUS DE TRANSMISIÓN

status of transmission

s. Grado de perfección en el que se encuentra un documento de archivo; esto es, borrador, original o copia [Archivos].

ESTIMACIÓN DE AUTENTICIDAD

Véase: "evaluación de autenticidad".

\section{ESTRATEGIA}

\section{strategy}

s. El conjunto de medios prácticos articulados formalmente por una organización con el fin de lograr un determinado propósito; esto es, un plan o ruta para implementar una política [Archivos-Strategy Task Force Report, p. 118].

\section{ESTRATEGIA DE MANTENIMIENTO}

\section{maintenance strategy}

s. Conjunto coherente de objetivos y métodos para proteger y mantener la accesibilidad de copias auténticas de documentos de archivo digitales a lo largo de las primeras etapas de la cadena de preservación [Archivos]. Véase también: "estrategia de preservación de documentos de archivo".

\section{ESTRATEGIA DE PRESERVACIÓN}

preservation strategy

Véase: "estrategia de preservación de documentos de archivo".

\section{ESTRATEGIA DE PRESERVACIÓN DE DOCUMENTOS DE ARCHIVO}

\section{records preservation strategy}

s. Conjunto coherente de objetivos y métodos para proteger y mantener -salvaguardar la autenticidad y asegurar 
la accesibilidad- componentes digitales e información relacionada a documentos de archivo digitales adquiridos a lo largo del tiempo, así como para poder reproducir los documentos de archivo auténticos interrelacionados y/o sus agregaciones archivísticas. También se le conoce como "estrategia de preservación" o estrategia de preservación permanente [Archivos]. Véase también: "compatibilidad retrospectiva", "conversión", "restauración de datos", "emulación", "encapsulado", "estrategia de mantenimiento", "normalización", "preservación de objetos persistentes", "reingeniería de software", "preservación tecnológica".

\section{ESTRATEGIA DE VALORACIÓN}

\section{appraisal strategy}

s. Las políticas, convenciones y reglas generales escritas de la entidad responsable de la preservación permanente que rigen la valoración de documentos de archivo [Archivos].

\section{ESTRUCTURA CORPORATIVA}

corporate body

Véase: "corporación".

\section{ESTRUCTURA FÍSICA}

\section{physical structure}

s. El orden físico para el almacenamiento de datos y su contenido en un documento compatible con SGML [Informática]. Véase también: "estructura lógica", "definición de tipo de documento". 
ESTRUCTURA LÓGICA

- logical structure

s. La organización sintáctica de los elementos de datos en un documento compatible con SGML [Informática]. Véase también: "estructura física".

\section{ETIQUETA DE MARCADO}

\section{mark-up tag}

s. Conjunto de símbolos y/o caracteres que indican el comienzo y final de un elemento en un documento digital, de acuerdo a una convención preestablecida de marcado. La etiqueta sirve como una instrucción al programa que va a interpretar ese elemento para tomar una acción o dar una respuesta [Informática]. Véase también: "esquema de un documento", "definición de tipo de documento".

\section{ETIQUETAR}

tag

Véase: "marcar".

\section{EVALUACIÓN}

\section{appraisal}

Véase: "valoración".

\section{EVALUACIÓN DE AUTENTICIDAD}

assessments of autbenticity

s. La determinación que establece si un documento posee todos los elementos formales que se asume debía presentar cuando fue elaborado o recibido la primera vez y separado (apartado o guardado) [Archivos]. 


\section{EVIDENCIA}

- evidence

s. Conjunto de medios mediante los cuales la veracidad de un supuesto asunto o hecho es sometida a investigación para ser probada o desaprobada [Archivos].

\section{EXACTITUD}

\section{accuracy}

s. Junto con la "autenticidad" y la "fiabilidad" es uno de los elementos que conforman la "confianza" de un documento de archivo; consiste en el grado en el que sus datos e información son precisos, correctos, veraces, libres de errores o distorsiones, así como el grado en que esos datos son perfecta o exclusivamente pertinentes a su asunto o materia [Archivos].

\section{EXHAUSTIVIDAD}

completeness

Véase: "completitud".

EXHIBICIÓN DE PRUEBAS ELECTRÓNICAS

electronic discovery

Véase: "e-hallazgo".

\section{EXPEDIENTE}

file

s. (De file, conjunto documental) La suma o conjunto integrado de documentos de archivo producidos o separados que participan en el mismo asunto o están relacionados con un mismo evento, persona, lugar, proyecto o materia, agregado de tal forma que pueda ser recuperado para una acción o como referencia. Son elaborados y recibidos por una persona física o jurídica en el desarrollo de actividades y preservados. También se le 
conoce como "dossier" [Archivos]. Véase también: "ítem", "serie", "fondo".

\section{EXPEDIENTE ELECTRÓNICO}

electronic file

s. La suma o conjunto integrado de documentos de archivo digitales producidos o separados que participan en el mismo asunto o están relacionados con un mismo evento, persona, lugar, proyecto o materia, agregado de tal forma que pueda ser recuperado por medios electrónicos para una acción o como referencia. Son elaborados y recibidos por una persona física o jurídica en el desarrollo de actividades y preservados [Archivos].

EXPEDIENTE DE CASO

\section{case file}

s. Una agregación de documentos de archivo relacionada a una acción, evento, proyecto, persona o materia específicos.

\section{EXPEDIENTE ORIGINAL}

original file

s. En el ambiente de archivos sobre soportes tradicionales, es un expediente que contiene originales de los documentos de archivo recibidos así como borradores y/o copias de los documentos de archivo enviados; es decir, el primer expediente completo y efectivo [Archivos].

\section{EXPOSICIÓN}

\section{exposition}

s. Uno de los elemento internos de la forma documental que comprende la parte del texto de un documento que describe las circunstancias concretas y explícitas que generan la acción y/o el documento [Diplomática] [Archi- 
Extensible markup...

vos-Duranti, Diplomatics: New Uses for an Old Science, pp. 6-24]. Véase también: Ontología A.

EXTENSIBLE MARKUP LANGUAGE

Véase: "Lenguaje de Marcado Extendido". 


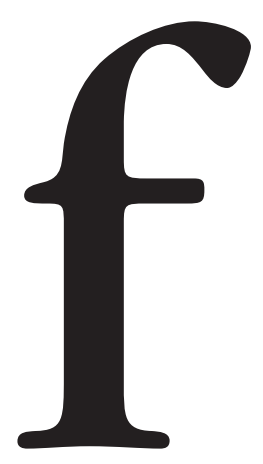

FASE DE EJECUCIÓN

\section{execution phase}

s. Un procedimiento administrativo constituido por todas las acciones (validación, comunicación, notificación, publicación) con las que se otorga carácter formal a una cierta transacción y al documento de archivo resultante [Archivos].

FEA

s. Acrónimo de "firma electrónica avanzada".

FECHA ARCHIVÍSTICA

- archival date

s. La fecha en la cual el documento de archivo es separado e incorporado en la agregación a la que pertenece y es clasificado [Archivos]. 
FECHA CRONOLÓGICA

- chronological date

s. La fecha y ocasionalmente la hora consignadas en un documento de archivo por su autor o por un sistema de cómputo a instrucción del autor, durante el curso de su compilación [Archivos]. Véase también: "fecha tópica".

\section{FECHA DE COMPILACIÓN}

compilation date

Véase: "fecha cronológica".

FECHA DE TRANSMISIÓN

transmission date

s. La fecha en que el documento de archivo deja el espacio en donde fue generado [Archivos-Duranti, Eastwood \& Macneil, Preservation of the Integrity of Electronic Records, p. 32].

\section{FECHA DEL DOCUMENTO}

\section{date of document}

s. La fecha y lugar (fecha tópica) o la fecha y ocasionalmente hora (fecha cronológica) de la compilación y/o elaboración de información capturada como documento de archivo [Archivos-Duranti, Eastwood \& Macneil, Preservation of the Integrity of Electronic Records, p. 71].

\section{FECHA DEL DOCUMENTO DE ARCHIVO}

\section{date of record}

s. La fecha asignada al documento de archivo por el autor [Archivos-Duranti, Eastwood \& Macneil, Preservation of the Integrity of Electronic Records, p. 33]. Véase también: Ontología A. 
FECHA DE RECEPCIÓN

date of receipt

s. La fecha en la que un documento es recibido por la agencia o dependencia a la cual fue enviado [ArchivosDuranti, Eastwood \& Macneil, Preservation of the Integrity of Electronic Records, p. 32].

\section{FECHA TÓPICA}

\section{topical date}

s. La fecha y lugar de construcción o compilación consignados en un documento de archivo por su productor o por un sistema de cómputo a instrucción del autor [Archivos]. Véase también: "fecha cronológica".

\section{FEDATARIO}

countersigner

s. Persona que, al firmar un documento de archivo, asume la responsabilidad de la forma y de la regularidad del procedimiento que generó el documento [Diccionario General].

\section{FIABILIDAD}

\section{reliability}

s. Junto con la "autenticidad" y la "exactitud" es uno de los elementos que conforman la "confianza" de un documento de archivo como declaración de un hecho; consiste en el grado en que un documento de archivo puede establecer, declarar o sostener al acto o hecho del que es relativo, y es establecida determinando la competencia del autor y examinando tanto la completitud en la forma del documento de archivo como el nivel de control ejercido durante su proceso de producción. En otras 
palabras, la fiabilidad es la confianza en el contenido de un documento de archivo [Archivos].

FICHERO (informática)

file

Véase: "archivo" (de file, objeto de información dentro de una computadora).

FIEL

s. Acrónimo de "firma electrónica".

FIJAR

\section{affix}

v. Grabar o almacenar información sobre un medio inalterable o no-volátil. A este proceso también se le denomina fijado. Véase también: "salvar" [Archivos].

FIJEZA

fixity

s. La calidad que tiene un documento de archivo, en cuanto a persistencia y continuidad, que lo hace inmutable y que por ello requiere de cambios específicos y documentados para ser actualizado u obtener una nueva versión [Archivos-Authenticity Task Force Report]. Véase también: "variabilidad vinculada", "forma fija", "estable".

\section{FIRMA}

signature

s. El nombre o marca especial de una persona, grafiada por propia mano o por su agente autorizado sobre un documento con propósito de hacerse responsable de algo, aprobarlo o validar parte de o todo su contenido [Archivos-Diccionario General]. 


\section{FIRMA DIGITAL}

\section{- digital signature}

s. Un conjunto de números en código basado en técnicas criptográficas de llave pública y/o privada que se embebe dentro de un documento digital con el fin de garantizar que ese documento no ha sido alterado o modificado en forma alguna desde su producción y firma. También se le conoce como "firma electrónica avanzada" o por sus siglas "FEA" o "FIEL" [Informática].

\section{FIRMA ELECTRÓNICA}

\section{electronic signature}

s. Una marca digital que al ser agregada o ser lógicamente asociada a un documento de archivo funge como una firma sobre el mismo, es usada por el firmante para asumir la responsabilidad u otorgar consentimiento sobre el contenido del documento de archivo [Informática].

FIRMA ELECTRÓNICA AVANZADA

Véase: "firma digital".

FONDO

archival fonds

fonds

s. El conjunto de los documentos de archivo que una persona física o jurídica acumula por razones de su función o actividad; es el nivel más alto de agregación archivística. Se le identifica también con los términos archivos o fondo archivístico [Archivos]. Véase también: "dossier", "archivo", "ítem", "serie de documentos de archivo".

FORMA

form

Véase: "forma documental". 
FORMA DE DOCUMENTOS DE ARCHIVO

records form

s. Especificaciones de las formas documentales para los distintos tipos de documentos de archivo de un productor [Archivos].

\section{FORMA DOCUMENTAL}

\section{documentary form}

s. Reglas de representación que establecen la apariencia de una entidad documental y según las cuales el contenido de un documento de archivo, su contexto jurídico-administrativo, documental y su autoridad son comunicados. La forma documental posee tanto elementos externos como internos. También se le conoce como "presentación documental" [Archivos]. Véase también: Ontología A.

\section{FORMA FIJA}

\section{fixed form}

s. Un objeto digital tiene forma fija si su contenido binario es almacenado de tal forma que el mensaje que contiene se puede desplegar con la misma presentación documental que tenía en la pantalla la primera vez que fue guardado, o si el mismo contenido estable puede ser desplegado con varias presentaciones documentales diferentes pero siempre dentro de una serie finita de posibilidades. Por ejemplo, un conjunto de datos estadísticos presentados como un gráfico de pay, un gráfico de barras o una tabla son presentaciones documentales diferentes del mismo documento de archivo almacenado con forma fija y contenido estable. Un ejemplo de diferentes presentaciones digitales es cuando el mismo contenido se pasa de formato doc a PDF [Archivos]. Véase también: "variabilidad vinculada", "fijeza", "estable". 
FORMA FÍSICA

physical form

s. El conjunto de los atributos de forma de un documento de archivo que determinan su aspecto externo [Diplomática] Véase también: "forma intelectual".

FORMA INTELECTUAL

\section{intellectual form}

s. El conjunto de atributos de forma de un documento de archivo que representan y comunican los elementos de la acción en la que está involucrado; esto es, su contenido así como sus contextos documental y administrativo inmediatos [Diplomática]. Véase también: "forma física".

\section{FORMATO}

format

s. La estructura y/o distribución de una entidad [Informática]. Véase también: "forma documental", "formato de archivo", "forma", "presentación general", "formato envolvente".

FORMATO DE ARCHIVO (DE CÓMPUTO)

file format

s. La organización de los datos dentro de los objetos digitales, usualmente diseñada para facilitar el almacenamiento, recuperación, procesamiento, presentación y/o transmisión de esos datos por medio de algún programa [Informática]. No debe confundirse esta definición, que habla de "archivo" desde el punto de vista informático, con los archivos desde la archivística. Véase también: "formato digital". 


\section{FORMATO DE DATOS}

data format

s. Organización de los datos dentro de los expedientes, usualmente diseñada para facilitar su almacenamiento, recuperación, procesamiento, presentación o transmisión por parte de los programas o aplicaciones computacionales [Informática].

FORMATO DE ENCAPSULADO

Véase: "formato envolvente".

\section{FORMATO DIGITAL}

digital format

s. La representación de un objeto digital codificada como bytes, la cual define reglas sintácticas y semánticas que permiten el mapeo o correspondencia de un modelo de información a una cadena de bits y viceversa. En la mayoría de los contextos, el término formato digital es usado indistintamente con conceptos relacionados a archivos digitales como formato de archivo, envoltura del archivo, codificación de archivo, etcétera. También se le conoce como "presentación digital" [Informática]. No debe confundirse esta definición, que habla de "archivo" desde el punto de vista informático, con los archivos desde la archivística. Véase también: "formato de archivo".

\section{FORMATO ENVOLVENTE}

\section{wrapper format}

s. Una estructura específica que se utiliza para contener o encapsular varias cadenas de bits en un solo archivo, por ejemplo, los archivos zip [Informática]. 
FORMATO LEGIBLE POR MÁQUINA

\section{machine-readable format}

s. Datos que pueden ser leídos, procesados e interpretados por computadoras y dispositivos similares. Op.: "formato legible por personas”. Un ejemplo es la versión HTML legible por computadora de una licencia Creative Commons dentro de un documento [Informática]. Véase también: "formato legible por personas", "lenguaje de máquina".

FORMATO LEGIBLE POR PERSONAS

\section{buman-readable format}

s. Un documento o código que puede ser leído por las personas, sin necesidad de amplificación o interpretación. Op.: "formato legible por máquina". Por ejemplo, la versión legible para personas de una licencia Creative Commons dentro de un documento [Informática]. Véase también: "formato legible por máquina", "lenguaje de máquina”.

\section{FORMATO LÓGICO}

\section{logical format}

s. Organización de archivos de computadora (files) que están sobre un medio digital de tal forma que tanto el conjunto de datos como sus estructuras de orden y control son reconocibles y recuperables por un dispositivo o computadora; por ejemplo, el formato ISO 9660/13490 para CD y el Universal Disk Format (UDF) para DVD [Informática].

FORMATO PERSISTENTE

\section{persistent format}

s. Un tipo de dato, simple o complejo, que es independiente de un cierto equipo o programa de cómputo es- 
pecífico, de tal forma que el objeto representado en este tipo de dato puede ser transferido de una plataforma computacional a otra sin alteración significativa de sus atributos o características esenciales [Informática]. Véase también: "autodescriptivo".

\section{FORMATO UNIVERSAL DE DISCO}

\section{universal disk format}

s. Una especificación estándar (ISO 13346) para sistemas de almacenamiento óptico independiente del fabricante; fue diseñada para intercambio de datos, permitiendo a los sistemas operativos leer y escribir datos en un medio óptico al margen del sistema operativo original de creación [Informática].

FÓRMULA A PERPETUIDAD

formula perpetuitatis

s. Un elemento interno de la forma documental que consiste en una oración declarando que los derechos puestos en existencia en el documento no prescriben con el tiempo [Diplomática] [Duranti, Diplomatics: New Uses for an Old Science, p. 144]. Véase también: Ontología A.

\section{FUNCIÓN}

function

s. El conjunto de actividades destinadas a lograr un propósito, considerado en forma abstracta [Archivos].

FUNCIÓN ARCHIVÍSTICA

records management function

Véase: "función de administración de documentos de archivo". 
FUNCIÓN DE ADMINISTRACIÓN DE DOCUMENTOS DE ARCHIVO records management function

s. El conjunto de actividades de un productor orientadas a la producción, uso y mantenimiento de documentos de archivo fiables que satisfagan sus necesidades y responsabilidades administrativas, legales, financieras e históricas [Archivos]. También se le conoce como "función archivística".

FUNCIONALIDAD

functionality

s. Las capacidades o habilidades de un programa o sus partes, o de un sistema computacional, vistas como la suma de todas sus características [Informática-Free OnLine Dictionary of Computing (FOLDOC)].

FUNCIONARIO DE CONFIANZA DE DOCUMENTOS DE ARCHIVO

\section{trusted records officer}

s. Dentro de una organización, la persona u oficina responsable de guardar y administrar los documentos de archivo de cierto productor. Esta persona u oficina no debe tener ningún interés creado para alterar o dejar alterar esos documentos y debe ser capaz de implementar todos los requerimientos para documentos auténticos [Archivos]. También se le denomina gestor o administrador de confianza de documentos de archivo. Véase también: "requerimientos para pruebas de autenticidad", "archivista", "administrador de documentos de archivo", "tercero de confianza", "preservador designado de documentos de archivo", "custodio", "custodio fiable". 


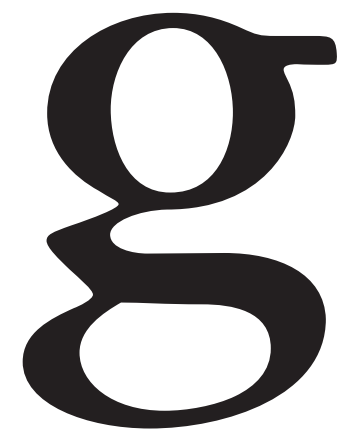

GESTIÓN ARCHIVÍSTICA

Véase: "mantenimiento de documentos de archivo".

GESTIÓN DE DOCUMENTOS

records management

Véase: "administración de documentos de archivo".

GESTIÓN DE DOCUMENTOS DE ARCHIVO

recordkeeping

Véase: "mantenimiento de documentos de archivo".

GESTOR DE DOCUMENTOS DE ARCHIVO

Véase: "administrador de documentos de archivo".

GIS

Acrónimo de Geographic Information System o "sistema de información geográfico”. 


\section{GLOSA}

gloss

s. Nota explicativa de una palabra o frase oscura, difícil de entender dentro de un texto; especialmente aquellas notas hechas entre líneas o al margen de un documento [Archivos]. Véase también: "anotación”, "marca”, "acotación", "anotación al margen", "apostilla".

\section{GRADO DE PERFECCIÓN}

\section{degree of perfection}

s. También llamado "nivel de perfección". Se refiere a la completitud, carácter primitivo y efectividad de un documento de archivo. Los tres grados o niveles de perfección de un documento de archivo son borrador, original y copia [Archivos]. Véase también: "estatus de transmisión", Ontología B.

\section{GUARDAR}

set aside

v. Declarar un documento de archivo y retenerlo (apartarlo, separarlo) para futura referencia o uso, generalmente en un sistema de mantenimiento de documentos de archivo [Archivos].

GUÍA

guideline

Véase: "lineamiento". 


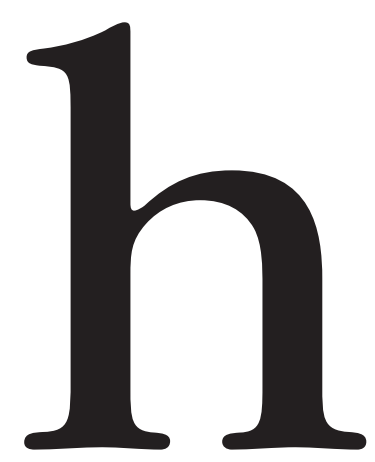

HECHO

fact

s. Un evento o condición existente y que es distinguible por sus efectos, consecuencias o interpretaciones, tales como el estado de las cosas o su transición [Diccionario General].

\section{HERRAMIENTA}

\section{tools}

s. Información, tecnología, equipo y/o suministro usados para administrar el ciclo de vida de los documentos de archivo [Archivos-cadena de preservación].

HTML

Acrónimo de Hypertext Markup Language o "Lenguaje de Marcado de Hipertextos". 


\section{HIPERTEXTO}

bypertext

s. Método para desplegar información digital sobre una pantalla que permite que ciertos segmentos del texto desplegado queden vinculados a otros archivos y elementos relacionados con ellos y pueda navegarse de unos a otros, sin seguir una secuencia lineal, a través de una selección del texto elegido, por lo general reconocible por estar marcado con otro color o subrayado usando el ratón [Informática]. 


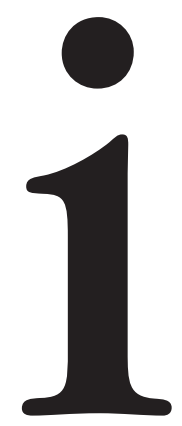

IDEFO

Véase: "método de modelado por definición de funciones integradas".

\section{IDENTIDAD}

identity

s. Junto con la "integridad", conforma la "autenticidad" de un documento. Consiste en el conjunto de características inherentes a un documento de archivo que lo identifican de forma única y lo distinguen de otros documentos de archivo. La identidad de un documento de archivo se establece y mantiene al indicar un mínimo de nombres de las personas que participaron en el proceso de producción (autor, destinatario, etcétera), la acción o asunto relativos al documento de archivo, las fechas de compilación, archivado o transmisión; su forma documental, su presentación digital o formato, su relación con otros documentos por medio de un código de clasificación o 
denominación, y la existencia de anexos [Archivos]. Véase también: Ontología C.

\section{IDENTIDAD DE UN DOCUMENTO DE ARCHIVO}

\section{record identity}

s. El carácter distintivo de un documento de archivo, identificable por medio de los atributos que lo caracterizan y permiten distinguir de forma única e inequívoca a ese documento de otros [Archivos-The InterPARES 1 Project Glossary, p. 363].

\section{IDENTIFICADOR}

\section{identifier}

s. Aquellos términos que pueden proveer indizado por materias además de los descriptores usuales temáticos de un documento, tales como acrónimos, nombres de proyectos, nombres propios, locaciones geográficas, números de patentes, nombres de pruebas o exámenes, marcas comerciales, etcétera [Informática-Harrod's Librarians' Glossary and Reference Book].

\section{IDENTIFICADOR UNIFORME DE RECURSOS}

\section{uniform resource identifier}

s. De URI, Uniform Resource Identifier. Nomenclatura que permite asignar un número único universal a un documento; por ejemplo, el ISBN para los libros o el DOI para los artículos.

\section{INCREMENTO DE FONDOS}

\section{accrual}

s. También llamado "transferencia de fondos" o "acumulación de fondos". La adquisición o traslado de nuevos 
fondos archivísticos de un productor hacia un preservador en adición a los fondos de ese productor que el preservador ya tenía en custodia [Archivos].

\section{INDICACIÓN DE ANEXOS}

indication of attacbements

s. La línea que menciona a otros documentos independientes que han quedado vinculados al documento de archivo antes de su transmisión, por ejemplo, durante su ejecución, a fin de lograr su propósito [Archivos].

INDICACIÓN DE ASUNTO O MATERIA

indication of action

s. La línea o líneas que explican el asunto o materia del documento de archivo, puestas en el espacio destinado para ello o en el título de éste [Archivos].

\section{INFORMACIÓN}

\section{information}

s. Un ensamble o conjunto organizado y coherente de datos procesados e interrelacionados que forman una unidad de significado más compleja que sus partes, con propósito de comunicarla en el espacio y el tiempo [Archivos].

\section{INFORMACIÓN ACTUALIZADA DE ALMACENAMIENTO}

\section{updated storage information}

s. Información que indica un cambio de ubicación de un componente digital almacenado, o la ocurrencia de un problema de almacenamiento así como la acción tomada para corregir el problema, los resultados de las acciones tomadas, o la copia de los componentes de un soporte antiguo de almacenamiento hacia uno nuevo [Archivos]. 
INFORMACIÓN DE VIABILIDAD

feasibility information

s. Evaluación del costo y capacidades técnicas requeridas para la preservación permanente de un cierto cuerpo de documentos de archivo [Archivos].

INFRAESTRUCTURA DE LLAVE PÚBLICA public key infrastructure

s. (PKI) Los sistemas necesarios que se construyen como soporte para el uso generalizado, confiable y masivo de sistemas de cifrado con llave pública y/o privada para la autenticación de personas que realizan operaciones de forma remota dentro de la red [Informática].

INGRESO

accession

s. 1. Toma de la custodia legal y física de un grupo de documentos de archivo registrando este hecho en un documento de archivo de ingreso o acta. 2. Resultado de la acción de tomar física y legalmente la custodia de un cuerpo documental archivístico, asentándolo en un acta. 3. Dícese del cuerpo documental formalmente aceptado en custodia como una sola unidad en una sola acción [Archivos]. También se le conoce como "recepción" [Archivos].

INICIALIZACIÓN

\section{initialization}

s. Conjunto o protocolo de órdenes o instrucciones que ponen a punto cierto dispositivo informático previo a su uso, por ejemplo, un escáner o una impresora [Informática]. 


\section{INSCRIPCIÓN}

\section{inscription}

s. Uno de los elementos internos de la forma documental que comprende el nombre, título y dirección del destinatario del documento y/o el asunto [Diplomática] [ArchivosDuranti, Diplomatics: New Uses for an Old Science, p. 144]. Véase también: Ontología A.

\section{INSTANCIA DE METADATOS}

\section{metadata instance}

s. Una colección específica de elementos de metadatos asociada a un conjunto de valores particular para esos elementos [Archivos].

INSTANCIACIÓN

\section{instantiation}

s. 1. Representación de una entidad abstracta por medio de una instancia concreta; en archivística, la manifestación de un documento de archivo digital (ente abstracto) en una forma visible y usable (ente concreto) [Archivos]. 2. Representación a través de una instancia competente.

\section{INSTRUMENTO DESCRIPTIVO}

\section{descriptive instrument}

s. Una herramienta preparada en el transcurso de la descripción archivística y del indizado de documentos de archivo con propósitos de control administrativo e intelectual de los mismos [Archivos]. Véase también: "documento(s) de archivo descrito(s)".

\section{INTEGRIDAD}

\section{integrity}

s. La cualidad de estar completo y sin alteraciones en todos los aspectos esenciales. Con la "identidad", es un 
componente de la "autenticidad" [Archivos]. Véase también: Ontología C.

INTEGRIDAD DEL DOCUMENTO DE ARCHIVO

\section{record integrity}

Véase: "integridad".

\section{INTERACTIVIDAD}

\section{interactivity}

s. Dentro de una serie de mensajes intercambiados en el proceso de comunicación, es la medida del alcance con que cada mensaje se relaciona con el previo, y a su vez entre éste y los mensajes precedentes [Informática].

\section{INTERFAZ DE PROGRAMACIÓN}

\section{application programming interface}

s. (API) Conjunto de rutinas, protocolos y otras herramientas usadas para facilitar y acelerar la construcción de programas y aplicaciones de cómputo; también se les denomina así a las convenciones para interactuar con el sistema operativo, los dispositivos de red, etcétera [Informática].

\section{INTEROPERABILIDAD}

\section{interoperability}

s. La capacidad que tienen programas y/o sistemas para comunicarse y trabajar conjuntamente con otros sin ajustes o cambios especiales [Informática]. Véase también: "compatibilidad", "multiplataforma".

\section{INTITULACIÓN}

\section{entitling}

s. Elemento interno de la forma documental que comprende nombre, título, capacidad y dirección de la persona física o jurídica que expide el documento y de la 
cual el autor del documento es su agente [Diplomática] [Archivos-Duranti, Diplomatics: New Uses for an Old Science, p. 143]. Véase también: Ontología A.

\section{INTRODUCCIÓN}

\section{introduction}

s. Parte de la forma intelectual del documento de archivo que se encuentra al inicio del mismo y usualmente contiene la identificación de las personas que concurren a su formación, su contexto jurídico-administrativo y su ubicación geográfica y temporal (fecha cronológica, lugar de origen, título, asunto, etcétera). También se le conoce como "protocolo" desde los documentos de archivo sobre soportes tradicionales.

\section{INVENTARIO}

\section{inventory}

s. Instrumento que describe los documentos de archivo dentro de un fondo de acuerdo con su arreglo y estructura jerárquica, y que además ilustra la historia administrativa de su productor, la historia de su custodia y los contextos administrativo y documental [Archivos].

\section{INVOCACIÓN}

\section{invocation}

s. Uno de los elementos internos de la forma documental que comprende la mención de Dios en documentos emitidos por personas o instituciones religiosas [Diplomática] [Archivos-Duranti, Diplomatics: New Uses for an Old Science, p. 143]. Véase también: Ontología A.

IPR

Acrónimo de Intellectual Property Rights o "derechos de propiedad intelectual". 
ISO

Acrónimo de International Organization for Standardization u Oficina Internacional de Estándares.

ÍTEM

item

s. La unidad archivística más pequeña, y por tanto indivisible; representa la entidad intelectual mínima dentro de la cual un fondo o documento de archivo no puede ser ya subdividido de manera útil con propósitos descriptivos [Archivos]. Véase también: "expediente", "serie", "fondo". 


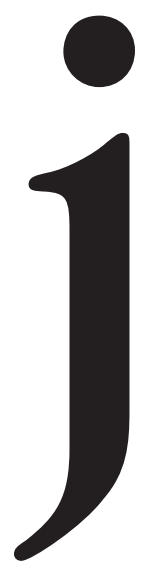

JERARQUÍA

bierarchy

s. Grupo de entidades interrelacionadas, o información acerca de estas entidades, dentro de un sistema arreglado por orden, grados y/o niveles, usualmente de lo general a lo particular [Diccionario General].

JERARQUÍA DE DATOS

data bierarchy

s. El sistema de objetos de datos que proporcionan los métodos para el almacenamiento y recuperación de la información. Por lo general una jerarquía de datos puede ser considera natural o de máquina [Informática].

JERARQUÍA DE MÁQUINA

macbine bierarchy

s. Un arreglo de datos que refleja todo lo instalado y disponible en una computadora dada, tanto en su equipo 
como en sus programas [Informática]. Véase también: "jerarquía natural".

\section{JERARQUÍA NATURAL}

natural bierarchy

s. Un arreglo de relación y pertenencia que surge de manera natural entre ciertos atributos y/o datos; por ejemplo: país, estado, ciudad; calle, número, código postal [Informática]. Véase también: "jerarquía de máquina”. 


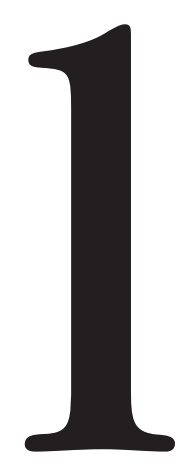

LAN

Acrónimo de Local Area Network o "red de área local".

\section{LEGITIMIDAD}

genuineness

s. Calidad de un documento de archivo de que es en efecto lo que pretende ser. Los dos conceptos que permiten una valoración indirecta de la legitimidad de un documento de archivo son la "fiabilidad" y la "autenticidad" [Archivos-Duranti, Eastwood \& Macneil, Preservation of the Integrity of Electronic Records, pp. 25, 77].

\section{LENGUAJE}

language

s. Uno de los elementos externos de la forma documental el cual comprende la expresión y la organización de las ideas y el discurso incluyendo composición, estilo, cadencia y vocabulario [Diplomática] [Archivos-Duranti, 
Diplomatics: New Uses for an Old Science, pp. 136-138]. Véase también: Ontología A.

\section{LENGUAJE DE MÁQUINA}

\section{machine language}

s. Conjunto de instrucciones para la unidad central de proceso (CPU) de una computadora, de forma tal que pueden ser directamente utilizadas por ésta sin necesidad de traducción o interpretación previa; también se le llama "código de máquina" [Informática]. Véase también: "formato legible por máquina”.

\section{LENGUAJE DE MARCADO}

\section{mark-up language}

s. Un sistema de codificación legible por máquina así como sus reglas asociadas, que son utilizados para describir la estructura lógica, distribución, forma de despliegue y estilo de un cierto documento digital. Existen varios lenguajes de marcado con diferentes reglas, propósitos y alcances; por ejemplo, el HTML, el SGML y el XML [Informática]. Véase también: "Lenguaje de Marcado de Hipertextos", "Lenguaje de Marcado Estándar Generalizado", "Lenguaje de Marcado Extendido".

\section{LENGUAJE DE MARCADO DE HIPERTEXTOS}

\section{HTML}

s. (Hyper Text Markup Language) Es un lenguaje de marcado de textos muy simple que se utiliza para crear textos y demás elementos de una página web. Está compuesto por etiquetas (marcas o tags) que definen la estructura y el formato de cada uno de los elementos que componen el documento que verá el usuario a través de la página web. Esas etiquetas son leídas por todos los navegadores o browsers web permitiendo que puedan ser visibles en 
cualquier computadora de forma homogénea, además de permitir el "hipertexto" [Informática]. Véase también: "SGML", "XML".

\section{LENGUAJE DE MARCADO ESTÁNDAR GENERALIZADO}

\section{SGML}

s. ("Standard Generalized Markup Language") Lenguaje de marcado estándar internacional ISO 8879:1886 utilizado para la definición formal de todo tipo de documentos, de manera que los hace ser independientes del dispositivo, sistema y programa con el cual fueron realizados [Informática]. Véase también: "HTML", "XML".

\section{LENGUAJE DE MARCADO EXTENDIDO}

$\boldsymbol{X M L}$

s. ("Extensible Markup Language") Lenguaje de marcado estándar internacional desarrollado por el World Wide Web Consortium o W3C. XML es una versión de SGML, diseñado especialmente para los documentos de la web. Permite que los diseñadores creen sus propias etiquetas, facilitando la definición, transmisión, validación e interpretación de datos entre programas y entre organizaciones. XML permite realizar funciones que no pueden lograrse con HTML [Informática]. Véase también: "SGML", "HTML".

\section{LINEAMIENTO}

\section{guidelines}

s. Una proposición u otra indicación de política o procedimiento formulada por un cuerpo con autoridad y conocimiento del tema dentro de una organización y que sirve para determinar acciones, lograr una tarea dada o lograr un conjunto de metas y objetivos. Por lo general los lineamientos tienen menos peso que un acuerdo o un es- 
tándar. También se le conoce como "directriz" [Diccionario General]. Véase también: "mejores prácticas", "regla", "política”, "directiva”, "estándar".

\section{LISTA DE ANOTACIONES}

\section{list of annotations}

s. Información documentada acerca de las anotaciones y/o adiciones hechas a un documento de archivo después de su producción [Archivos].

LISTA DE CAMBIOS DE FORMATO

list of changes of format

s. Información documentada acerca de las modificaciones a la forma documental de un documento de archivo o a su formato digital después de su producción [Archivos].

\section{LOCAL AREA NETWORK}

Véase: "red de área local".

\section{LLAVE PRIVADA}

\section{private key}

s. En un sistema de cifrado o encriptado con llave pública es aquella parte de un par de llaves informáticas que queda bajo custodia de la entidad legal del sistema de autenticación, está protegida por una contraseña y sólo es conocida por el usuario autorizado de la llave [Informática]. Véase también: "llave pública", "sistema de cifrado con llave pública”, "infraestructura de llave pública”.

\section{LLAVE PÚBLICA}

\section{public key}

s. En un sistema de cifrado o encriptado con llave pública es aquella parte del par de llaves informáticas de un usuario que es del dominio público [Informática]. Véase 
también: "llave privada", "sistema de cifrado con llave pública", "infraestructura de llave pública".

LOCALIZADOR UNIFORME DE RECURSOS WEB

Uniform Resource Locator

s. (URL) Nomenclatura universalmente estandarizada para representar la localización de un objeto dentro de la web, como un sitio web, un documento, etcétera. También se le conoce como "Universal Resource Locator" [Informática].

LONGEVIDAD

- longevity

s. Larga duración de existencia [Diccionario General].

\section{LUGAR DE ORIGEN}

place of origin

s. Parte de la introducción de un documento de archivo; contiene el nombre del lugar geográfico donde éste se generó y que se encuentra dentro del documento o en el sistema electrónico por parte del autor. 


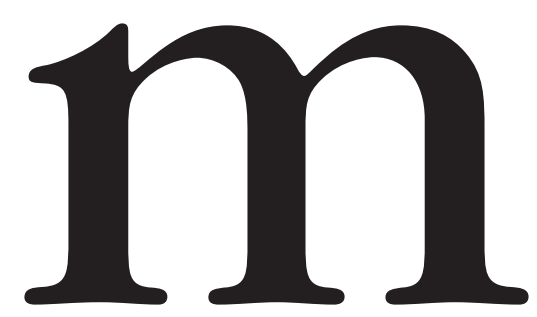

MAN

Acrónimo de Metropolitan Area Network o "red de área metropolitana".

MANDATO

literary warrant

Véase: "precepto".

MANDATO INTERNO

internal mandates

s. La autoridad derivada de una autoridad externa dentro de un cierto ambiente, otorgada por un cuerpo con autoridad a un subsidiario o depositario para que realice ciertas funciones [Archivos-Eastwood, Hofman \& Preston, Modeling Digital Records...].

MANIFESTAR

manifest

v. Representar un objeto digital que se encuentra almacenado hacia una forma apropiada para su presen- 
tación a una persona (forma legible por humanos) o a una computadora (forma legible por máquina) [Archivos]. Véase también: "reconstituir".

\section{MANTENIMIENTO DE DOCUMENTOS DE ARCHIVO}

\section{recordkeeping}

s. El conjunto de principios, políticas, reglas y estrategias empleado por un productor de documentos de archivo con el fin de establecer y mantener el control físico, intelectual y administrativo de esos documentos [Archivos]. También se le denomina "gestión de documentos de archivo", "gestión de documentos", "gestión archivística" y "tenencia de documentos de archivo". Es un subconjunto de la "administración de documentos de archivo" [Archivos].

\section{MANTENIMIENTO DIGITAL}

\section{digital maintenance}

s. Acciones tomadas para anticipar, prevenir, detener o retardar el deterioro del soporte de obras digitales con objeto de tenerlas permanentemente en condiciones de usabilidad; comprende la estabilización tecnológica y la migración a nuevos soportes, sistemas y formatos digitales para garantizar la trascendencia de los contenidos [Archivos].

\section{MAPA DE BITS}

\section{bitmap}

s. Representación digital de una imagen que consiste en una rejilla matricial o raster compuesta de puntos o celdas arreglados en líneas y columnas, cada uno de ellos representado por un conjunto de datos numéricos que determinan la posición y el valor del color de cada punto o píxel y que en combinación crean una impresión visual de líneas, sombras o matices específicos dentro de una imagen mono o policromática en la pantalla de 
una computadora o sobre una hoja impresa. También se le denomina imagen rasterizada, gráfico rasterizado o imagen matricial [Informática].

MAPA DE DATOS

data grid

s. Es una representación gráfica de una base de datos y sus relaciones de acuerdo a un diccionario de datos, con miras a tener una mejor perspectiva del diseño y estructura de la base. Se usa como herramienta para que las personas no familiarizadas con esa base de datos puedan entenderla de una manera sencilla y rápida [Informática].

\section{MAPEO DE INFORMACIÓN}

\section{information mapping}

s. Trazado de un mapa o tabla de elementos de datos correspondientes hecho entre dos conjuntos de datos distintos.

\section{MAPEO DE METADATOS}

\section{metadata mapping}

s. Una identificación formal de elementos de metadatos o grupos de ellos que sean equivalentes o semejantes, hecha entre distintos esquemas de metadatos con el propósito de establecer interoperabilidad semántica y funcional [Archivos-AGLS, AGLS Victoria: Metadata Implementation Manual].

MARCA

\section{mark-up}

s. Cada una de las etiquetas o códigos (marcas) agregados a partes de un documento digital con el fin de dar estructura semántica a esas partes y a todo el contenido. También se le conoce como etiqueta [Informática]. 
MARCA DE AGUA ELECTRÓNICA O DIGITAL

\section{digital watermark}

s. Un código numérico agregado a un documento digital que no interfiere con su uso normal y por lo general no es perceptible por el usuario, pero que bajo ciertas manipulaciones técnicas puede hacerse visible o audible por su productor para atestiguar la propiedad intelectual de su contenido.

\section{MARCAR}

\section{mark-up}

v. Adjuntar códigos o etiquetas (marcas) a partes de un documento digital con el fin de dar estructura semántica a esas partes y a todo el contenido. También se le conoce como "etiquetar" [Informática]. Véase también: "definición de tipo de documento", "lenguaje de marcado", "Lenguaje de Marcado Estándar Generalizado", "Lenguaje de Marcado Extendido", "esquema de un documento".

\section{MARCO DE REFERENCIA}

\section{framework}

s. Una estructura conceptual básica formada por reglas, políticas, procedimientos, herramientas y mecanismos cuyo objetivo es servir como base para el diseño, implementación y mantenimiento de un sistema [Diccionario General].

\section{MARCO DE REFERENCIA}

\section{archival framework}

s. El conjunto de políticas, estrategias y procedimientos basados en conceptos, principios y métodos archivísticos que controlan el mantenimiento y la preservación documental [Archivos]. 
MATERIA

subject line

Véase: "asunto".

MEDIO

\section{medium}

s. 1. Material físico o sustancia sobre la cual la información se registra o almacena. También se le conoce como "soporte" o medio escriptorio. Véase también: "componente físico", "medio digital", "medio analógico" [Informática]. 2. Uno de los elementos externos de la forma documental que describe el tipo de material sobre el que va el mensaje [Diplomática]. Véase también: Ontología A.

\section{MEDIO ANALÓGICO}

\section{analogue medium}

s. Soporte físico, tal como papel, pergamino, piedra, arcilla, película o los antiguos tipos de cintas de audio y video magnéticas, usadas para almacenamiento de datos en forma analógica [Archivos]. Véase también: "medio digital", "objeto analógico".

\section{MEDIO DIGITAL}

\section{digital medium}

s. También se le llama soporte digital. Es el material físico, tal como un disco compacto, DVD, cinta o disco duro usado como soporte para almacenamiento de datos digitales [Informática]. Véase también: "medio", "medio analógico".

\section{MEJORES PRÁCTICAS}

\section{best practice}

s. Se dice del procedimiento que al ser aplicado apropiadamente desde una teoría a situaciones de la vida real, rinde resultados superiores consistentemente y es por 
tanto punto de referencia al momento de evaluar la eficacia contra otros métodos alternativos utilizados para desempeñar la misma tarea [Diccionario General]. Véase también: "lineamiento", "regla", "política", "estándar".

\section{METADATO}

\section{metadata}

s. 1. Información que caracteriza o describe a otro recurso de información, especialmente con propósito de documentar, describir, preservar o administrar ese recurso [Diccionario General]. 2. Cualquier archivo o base de datos que guarde información acerca de documentos, documentos de archivo, agregación de ellos, o cualquier otra de sus estructuras, así como sus atributos, procesos y cambios [Archivos].

\section{METADATO DE IDENTIDAD}

- identity metadata

s. Propiedades o atributos que conllevan la identidad de un objeto digital que tiene que mantenerse como documento de archivo [Archivos].

\section{metalanguage}

s. Medio para referirse y definir formalmente un lenguaje dado. En este contexto, HTML, SGML, XML son en realidad metalenguajes ya que se usan para referirse y explicar, desde el punto de vista de su estructura formal o sintáctica, el funcionamiento del lenguaje que describe a esos formatos [Informática]. 
MÉTODO DE MODELADO POR DEFINICIÓN

DE FUNCIONES INTEGRADAS IDEFO

\section{integrated definition function} modeling method IDEFO

s. Técnica diseñada para modelado de toma de decisiones, acciones y actividades dentro de una organización o sistema [Informática].

MÉTODO CIENTÍFICO

scientific method

s. Aproximación rigurosa y sistémica diseñada para eliminar sesgos y otras influencias subjetivas dentro de una investigación, identificación, medida y/o validación de hechos y relaciones causa-efecto, de la que se pueden deducir leyes y principios científicos [Ciencias].

\section{METODOLOGÍA}

\section{metbodology}

s. El sistema o conjunto de principios y/o reglas de los cuales se derivan procedimientos o métodos específicos necesarios para comprender diferentes situaciones o resolver ciertos problemas, desde el enfoque de una disciplina en particular [Diccionario General].

METODOLOGÍA ARCHIVÍSTICA

\section{archival metbodology}

s. 1. La aplicación de principios y procedimientos articulados y desarrollados desde la teoría archivística. 2. El análisis, registro y mantenimiento de los vínculos entre la función de la información registrada por un lado y su forma, estructura y contexto de procedencia por el otro [Archivos]. 
MIGRACIÓN

\section{migration}

s. El proceso de mover o transferir objetos digitales de un sistema hacia otro [Informática]. Véase también: "refrescado", "migración transformativa”.

\section{MIGRACIÓN DE DOCUMENTOS DE ARCHIVO}

\section{migration of records}

s. El proceso de mover documentos de archivo de un sistema que se hace obsoleto hacia otro más moderno con el fin de asegurar su accesibilidad continuada, dejando intacta su forma física y su contenido intelectual [Informática]. Véase también: "conversión”, "refrescado de documentos de archivo", "migración transformativa".

\section{MIGRACIÓN TRANSFORMATIVA}

\section{transformative migration}

s. El proceso de convertir o actualizar sistemas y/o objetos digitales hacia nuevas generaciones de tecnología computacionales, tanto en equipo como en programas, formatos, etcétera [Informática]. Véase también: "conversión", "migración", "refrescado de documentos de archivo", "actualización", "migración transformativa de documentos de archivo".

\section{MIGRACIÓN TRANSFORMATIVA DE DOCUMENTOS DE ARCHIVO}

\section{transformative migration of records}

s. El proceso de conversión de documentos de archivo en el curso usual y ordinario de las operaciones propias de la organización (de otra manera la actividad no es migrar sino producir), con propósitos de asegurar la compatibilidad con nuevas generaciones o configuraciones de equipo y programas de cómputo, dejando intacta su forma intelectual [Informática]. Véase también: "conversión de 
documentos de archivo", "migración de documentos de archivo", "refrescado".

\section{MODELO}

\section{model}

s. Descripción esquemática y abreviada de un sistema, teoría, estructura o fenómeno a partir de una abstracción de características conocidas y relevantes de éstos con el propósito de efectuar mayores estudios sobre el modelo y así inferir causas y efectos en el ente real que representa [Diccionario General].

MODELO DE CONTINUIDAD DE LOS DOCUMENTOS DE ARCHIVO records continuum model

Véase: "continuidad de los documentos de archivo".

MODELO DE LA CADENA DE PRESERVACIÓN

- chain of preservation model

Véase: "cadena de preservación".

MODELO DE DATOS

\section{data model}

s. Es un producto de la etapa de diseño de una base de datos cuyo objetivo es identificar y organizar los datos tanto lógica como físicamente. Un modelo de datos dice cuál información estará contenida en la base de datos, cómo se usará esa información y cómo se interrelacionarán entre sí los elementos dentro de la base de datos [Archivos].

\section{MODO DE TRANSMISIÓN}

\section{mode of transmission}

s. El método, vía o manera en que se envía o transmite un documento de archivo, por ejemplo: fax, correo electrónico, etcétera [Archivos]. 


\section{MULTIPLATAFORMA}

cross-platform

s. La capacidad de sistemas y/o programas de cómputo para ejecutarse y percibirse en forma idéntica en distintas marcas y modelos de computadoras; ello se logra generalmente gracias al uso de normas, productos, formatos abiertos y estándares. También se le conoce como independiente de la plataforma, neutral a la plataforma [Informática]. Véase también: "compatibilidad", "interoperabilidad". 


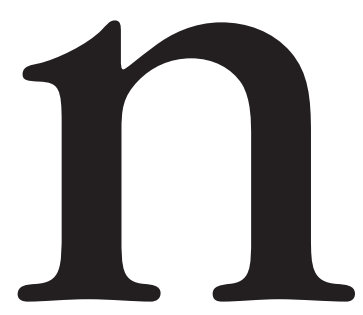

NACIDO DIGITAL

born digital

Véase: "digital de origen".

NARRACIÓN

narrative

s. (De un documento) Evidencia escrita de una actividad, no tiene relevancia jurídica [Archivos-Duranti, Diplomatics: New Uses for an Old Science, p. 68]. Véase también: "disposición", "probatorio".

NIVEL DE PERFECCIÓN

degree of perfection

Véase: "grado de perfección".

NO PROPIETARIO

non-proprietary

s. Se llama así a las tecnologías de equipo, programas y aplicaciones de cómputo y/o formatos de archivos que no 
se encuentran protegidos por una patente o marca o que no son poseídos ni controlados por una sola compañía o institución, o cuyo uso es permitido bajo esquemas de acceso abierto. Op.: "propietario" [Informática]. Véase también: "arquitectura abierta”, "acceso abierto".

NO REPUDIO

\section{non-repudiation}

s. La capacidad de un servicio de seguridad digital de certificar que un cierto mensaje transferido ha sido enviado y recibido por las partes que dicen ser, ofreciendo prueba de la integridad y origen del mensaje y sus datos, en una forma no falsificable que puede ser verificada por cada una de las partes en cualquier momento [Diccionario General]. Véase también: "copia autorizada".

NOMBRE DE ASUNTO O MATERIA

name of action or matter

s. La línea o líneas que explican el asunto o materia del documento de archivo puestas en el espacio destinado para ello o en el título. También se le conoce como "indicación de asunto o materia" [Archivos].

NOMBRE DEL DESTINATARIO

\section{addressee's name}

s. El nombre de la persona a quien se dirige o para quien se pretende el documento de archivo [Archivos].

\section{NOMBRE DEL ESCRITOR}

\section{writer's name}

s. El nombre de las personas físicas o puestos responsables de articular el contenido de un documento de archivo [Archivos]. Véase también: Ontología A. 
NOMBRE DEL LUGAR DE ORIGEN DEL DOCUMENTO DE ARCHIVO name of place of origin of record

s. El nombre de la ubicación geográfica donde el documento de archivo fue generado; va incluida en el contenido del documento de archivo por parte del productor o por el sistema electrónico por encargo del autor [Archivos].

NOMBRE DEL ORIGINADOR

\section{originator's name}

s. El nombre de la persona desde cuya dirección electrónica ha sido enviado un documento de archivo [Archivos-Duranti, Eastwood \& Macneil, Preservation of the Integrity of Electronic Records, p. 33].

NOMBRE DEL RECEPTOR recipient's name

s. El nombre de la persona u oficina que recibe un documento de archivo [Archivos-Duranti, Eastwood \& Macneil, Preservation of the Integrity of Electronic Records, p. 76].

NORMALIZACIÓN

normalization

s. El proceso de producir, almacenar o ajustar documentos digitales u otros objetos digitales en una forma tipificada o estandarizada de datos o formatos de archivo limitando su variedad [Archivos]. Véase también: "codificación duradera", "estrategia de preservación de documentos de archivo".

NOTA MARGINAL

marginalia

s. Señal o apuntamiento que se pone al margen de algún escrito o impreso y que comenta, interpreta o completa 
un texto [Diccionario General]. También se le conoce como "acotación".

NOTA SECRETARIAL

secretarial note

s. Uno de los elementos internos de la forma documental que comprende los diversos tipos de notas administrativas secretariales que pueden aparecer en un documento, tales como las iniciales del mecanógrafo, la mención de anexos o la indicación de que se envía copia del documento a otras personas [Diplomática] [Archivos-Duranti, Diplomatics: New Uses for an Old Science, p. 149]. Véase también: Ontología A.

\section{NOTIFICACIÓN}

\section{notification}

s. Uno de los elementos internos de la forma documental que comprende la comunicación del sentido o propósito del documento a todos los interesados en el acto consignado en él [Diplomática] [Archivos-Duranti, Diplomatics: New Uses for an Old Science, p. 113].

s. Un número de folio consecutivo asignado a cada documento de archivo entrante o saliente en el registro de protocolo, el cual lo vincula a documentos de archivo previos o subsecuentes elaborados o recibidos por el productor [Archivos-InterPARES, “Template for Analysis”, p. 198]. 


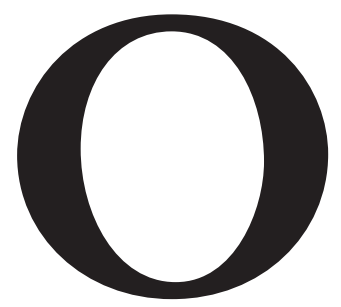

OBRA

\section{work}

s. Expresión distintiva del pensamiento o emociones humanas hecha a través del lenguaje, señas, números, imágenes, actuación o alguna otra forma, con propósito de comunicación y remembranza [Archivos]. Véase también: "documento", "documento de archivo".

\section{OBJETO}

\section{object}

s. Cualquier entidad concreta. A los documentos se les llama en la actualidad objetos documentales para abarcar todas sus posibles variantes: libros, documentos de archivo, revistas, tesis, imágenes, partituras, fotografías, grabaciones sonoras, video, etcétera. Véase también: "objeto digital", "objeto analógico" [Archivos]. 


\section{OBJETO ANALÓGICO}

\section{analogue object}

s. Agregación de valores continuos de datos acerca de un objeto documental representado en forma analógica (texto, audio, imagen, video, etcétera) [Informática]. Véase también: "objeto digital".

\section{OBJETO DE INFORMACIÓN}

\section{information object}

s. Una entidad digital o grupo de entidades -con independencia del tipo o formato- que puede direccionarse o tratarse como un solo objeto por parte de una computadora. También se le denomina recurso de información u "objeto digital" [Informática].

\section{OBJETO DIGITAL}

\section{digital object}

s. Objeto documental representado numéricamente por una agregación de valores discretos (diferenciados o discontinuos) de una o más cadenas de bits, con datos acerca del objeto documental representado así como de los metadatos acerca de las propiedades del mismo y, cuando sea necesario, los métodos para realizar operaciones sobre el objeto [Informática]. Véase también: "objeto analógico", "variable discreta".

\section{OBJETO DIGITAL ALMACENADO}

\section{stored digital object}

s. Un objeto digital que es guardado en un sistema de almacenamiento o en un soporte digital [Archivos]. 


\section{OBJETO HEREDADO}

legacy

s. Describe un objeto documental heredado desde un contexto o ambiente administrativo y/o tecnológico anterior que puede requerir alguna intervención o acción deliberada, como una actualización, mejora, conversión o migración transformativa para permitir que el objeto pueda ser accesible, presentado, manifestado, utilizado, mantenido, manejado y/o preservado en el ambiente o contexto actual como objeto activo.

\section{OBJETO PERSISTENTE}

persistent object

s. Un objeto digital normalizado a un formato persistente y encapsulado de tal forma que es autodescriptivo y por tanto legible en una nueva plataforma [Informática].

\section{OBSOLESCENCIA}

\section{obsolescence}

s. Estado de un equipo, programa o estructura que ya se considera anticuado, poco adecuado a las circunstancias actuales, que ha caído en desuso o está cerca de ello [Diccionario General].

OCTETO

Véase: "byte (carácter)".

\section{OFICIAL DE DOCUMENTOS DE ARCHIVO}

\section{records officer}

Véase: "funcionario de confianza de documentos de archivo". 


\section{OFICIAL RESPONSABLE}

\section{handling person}

Véase: "oficina responsable".

OFICINA DE GESTIÓN DE DOCUMENTOS DE ARCHIVO recordkeeping office

Véase: "oficina de mantenimiento de documentos de archivo".

\section{OFICINA DE MANTENIMIENTO DE DOCUMENTOS DE ARCHIVO} recordkeeping office

s. La oficina que tiene la competencia formal por parte del productor para diseñar, implementar y mantener dentro de la organización el "sistema de mantenimiento de documentos de archivo" [Archivos]. También se le conoce como "oficina de gestión de documentos de archivo".

\section{OFICINA DE RESPONSABILIDAD PRIMARIA}

\section{office of primary responsability}

s. La oficina que tiene la competencia expresa de mantener copias autorizadas o copia de los documentos de archivo pertenecientes a una cierta clase dentro del cuadro de clasificación [Archivos-InterPARES, "Requirements for assessing and maintaining the authenticity of electronic records", p. 217].

\section{OFICINA RESPONSABLE}

\section{bandling office}

s. La oficina y su titular formalmente competentes para llevar a cabo cierta acción que describe o trata el documento de archivo o a la que es pertinente [Archivos]. 
ORGANIZACIÓN

- organization

s. Sistema social que tiene una identidad colectiva inequívoca, un listado preciso de miembros o puestos, un programa de actividades y procedimientos para reemplazar a los miembros [Gobierno].

\section{ORIGINADOR}

\section{originator}

s. Una de las cinco personas de un documento de archivo digital. Es la persona o personas físicas, jurídicas o puestos a quienes fue asignada la cuenta electrónica o ambiente tecnológico donde los materiales son producidos o desde donde son transmitidos (este dato es relevante cuando ni el autor ni el escritor son las personas responsables de producir y/o transmitir el documento). Un ejemplo de ello es un correo electrónico cuyo remitente sea una persona y tenga un documento anexo de otro autor [Archivos].

\section{ORIGINAL}

original record

Véase: "documento de archivo original".

ORIGINALMENTE DIGITAL

born digital

s. Generado inicialmente en forma digital. Que no existió previamente en forma analógica.

ORIGINALIDAD

\section{primitiveness}

Véase: "carácter primitivo". 


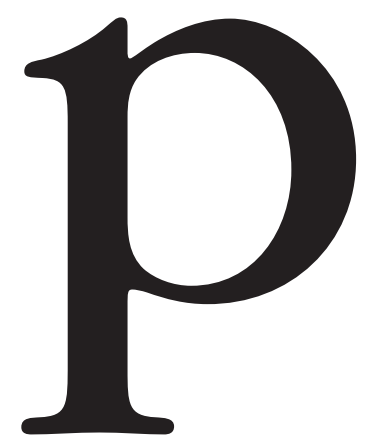

PAQUETE

packet

s. Parte de un mensaje transmitido a través de una "red de conmutación de paquetes”, por ejemplo, el correo electrónico. Una de sus características clave consiste en que cada paquete contiene la dirección de destino además de los datos en sí. Un conjunto de paquetes conforma un mensaje completo [Informática].

\section{PERFECCIÓN}

\section{perfect}

s. Calidad de un documento de estar completo, terminado, sin defectos y ejecutable [Diplomática] [ArchivosDuranti, Diplomatics: New Uses for an Old Science, p. 49].

PERFIL

\section{profile}

s. Un análisis representativo del grado o nivel en el que una entidad presenta ciertas características peculiares [Diccionario General]. 


\section{PERFIL DE APLICACIÓN}

\section{application profile}

s. También llamado "modelo de datos", consiste en una descripción de las reglas que rigen el vocabulario, el contenido y las estructuras que se pueden utilizar para difundir información entre conjuntos de datos heterogéneos dentro de un sistema, sin necesidad de realizar modificaciones a subsistemas locales [Archivos].

\section{PERFIL DE DOCUMENTO DE ARCHIVO}

\section{record profile}

s. Forma electrónica diseñada para contener los atributos de un documento de archivo que testifican su identidad e integridad, la cual es generada cuando el productor pretende enviar o cerrar un documento de archivo electrónico. Esta forma permanece inextricablemente vinculada al documento de archivo durante toda su existencia [Archivos-Duranti, Eastwood \& Macneil, Preservation of the Integrity of Electronic Records, p. 15].

\section{PERSONA}

\section{person}

s. 1. Un individuo o alguna entidad jurídicamente establecida que es sujeto de derechos y obligaciones, por lo cual tiene la capacidad y potencial de actuar legalmente [Diccionario General]. 2. Sujeto encargado de llevar a cabo actos o acciones en un documento de archivo [Diplomática-Duranti, Diplomatics: New Uses for an Old Science, p. 83]. Véase también: "personas", "persona física", "persona jurídica", "persona moral", "destinatario", "autor", "originador", "receptor", "escritor”, "productor”, Ontología A. 


\section{PERSONA COMPETENTE}

\section{competent person}

s. La persona física o jurídica a la que se ha otorgado la autoridad y la capacidad de actuar dentro de un marco específico de responsabilidad [Archivos].

PERSONA FÍSICA

\section{physical person}

s. Individuo que posee derechos y obligaciones naturales y que tiene la capacidad de actuar en su derecho en relación con terceros [Diccionario General-Duranti, Diplomatics: New Uses for an Old Science, p. 83].

\section{PERSONA JURÍDICA}

- juridical person

s. Entidad que tiene la capacidad o el potencial para actuar legalmente y que está constituida por una sucesión o grupo de personas físicas o jurídicas, en algunos países también por un grupo de propiedades. Se le conoce igualmente como "persona moral" [Diccionario General].

\section{PERSONA MORAL}

Véase: "persona jurídica".

PERSONAS

\section{persons}

s. Uno de los seis componentes intelectuales de un documento de archivo digital. Son los individuos u organizaciones con personalidad jurídica capaces o encargados de llevar a cabo legalmente actos o acciones; se requiere de al menos tres de ellos en un documento de archivo tradicional (autor, destinatario y escritor) y de cinco de 
ellos en un documento de archivo digital (autor, destinatario, escritor, productor y originador, este último puede ser el autor). Este componente permite hacer la distinción entre documentos de archivo y objetos digitales resultantes de la simple consulta a una base de datos. También se les llama "actores".

\section{PERTINENCIA}

\section{pertinent}

s. Calidad de un documento de archivo de que su contenido sea relevante al propósito para el cual fue producido o usado. Junto con "precisión", "corrección" y "veracidad" es un componente de la "exactitud" [Diplomática].

\section{PETICIÓN INTERNA DE DOCUMENTOS O INFORMACIÓN}

\section{internal requests for records or information}

s. Petición de usuarios dentro de la organización para consultar o recibir documentos de archivo, sus agregaciones, o información acerca de los documentos de archivo [Archivos-Eastwood, Hofman \& Preston, Modeling Digital Records...].

PKC

Acrónimo de Public Key Cryptosystem o "sistema de cifrado con llave pública”.

PKE

Acrónimo de Public Key Encryption o "sistema de cifrado con llave pública”.

PKI

Acrónimo de Public Key Infrastructure o "infraestructura de llave pública”. 


\section{PLATAFORMA}

\section{platform}

s. La combinación específica de un cierto tipo de equipo de cómputo y su sistema operativo, la cual le otorga características y comportamientos definidos y preestablecidos; suele ser similar entre modelos o familias de computadoras [Informática].

PLATAFORMA INDEPENDIENTE

platform-independent

Véase: "multiplataforma".

PLATAFORMA NEUTRAL

platform-neutral

Véase: "multiplataforma".

POLÍTICA

\section{policy}

s. Proposición formal de dirección y guía acerca de cómo una cierta organización llevará a cabo su mandato, funciones y actividades, y que es motivada y dirigida hacia ciertos intereses y/o programas [Archivos-Strategy Task Force Report, p. 118]. Véase también: "mejores prácticas", "lineamiento", "regla", "estándar".

\section{PONDERACIÓN DEL VALOR}

\section{assessing value}

s. El proceso de determinar el valor de los documentos de archivo [Archivos].

POP

Acrónimo de Persistent Object Preservation o "preservación de objeto persistente”. 
PREÁMBULO

preamble

s. Elemento interno de la forma documental que comprende la parte del texto de un documento que expresa las ideas que motivan la acción del documento [Diplomática] [Archivos-Duranti, Diplomatics: New Uses for an Old Science, p. 112]. Véase también: Ontología A.

\section{PRECEPTO}

\section{literary warrant}

s. La disposición legal y las recomendaciones de "mejores prácticas” o de literatura profesional archivística así como de otras fuentes que instruyen la producción y mantenimiento de la descripción archivística y otros metadatos que apoyen la "precisión", "fiabilidad", "autenticidad" y preservación de documentos de archivo [Archivos]. También se le conoce como "mandato".

\section{PRECISIÓN}

\section{precise}

s. Calidad de un documento de archivo de apegarse estrictamente en cada detalle de su forma y contenido a un estándar, guía o convención preestablecidos. Junto con "corrección", "veracidad" y "pertinencia" es un componente de la "exactitud" [Diplomática].

\section{PRESENTACIÓN DIGITAL}

digital presentation

Véase: "formato digital".

PRESENTACIÓN DOCUMENTAL

documentary presentation

Véase: "forma documental". 
PRESENTACIÓN GENERAL

\section{overall presentation}

s. Uno de los elementos externos de la forma documental relacionado con la configuración de la información general del documento de archivo; por ejemplo, la manera en la que el contenido es presentado a los sentidos usando texto, imagen o sonido, ya sea por separado o combinados [Diplomática] [Archivos-InterPARES, "Template for Analysis", pp. 192-193]. Véase también: "forma", "formato", "características específicas de presentación”, Ontología B.

\section{PRESERVACIÓN}

\section{preservation}

s. La totalidad de principios, políticas, reglas y estrategias destinadas a prolongar la existencia de un objeto manteniéndolo en una condición adecuada para su uso, ya sea en su formato original o en otro más persistente, dejando intacta la forma intelectual del objeto [Archivos]. Véase también: "preservación de documentos de archivo", "preservación de objeto persistente".

\section{PRESERVACIÓN ARCHIVÍSTICA}

\section{archival preservation}

s. Estabilización y protección física y tecnológica del contenido intelectual de documentos de archivo para su secuencia de preservación continuada, perdurable, estable, duradera, ininterrumpida, inquebrantada, sin un final previsto. Véase también: "preservación digital", "preservación permanente", "preservación de objeto persistente".

\section{PRESERVACIÓN DE DOCUMENTOS DE ARCHIVO}

\section{records preservation}

s. El conjunto de principios, políticas, reglas y estrategias que rigen la estabilización física y tecnológica así como 
la protección del contenido intelectual de documentos de archivo adquiridos, con objeto de lograr en ellos una secuencia de preservación continuada, perdurable, estable, duradera, ininterrumpida, inquebrantada, sin un final previsto [Archivos]. Véase también: "preservación", "preservación digital", "preservación de objeto persistente", "mantenimiento digital".

\section{PRESERVACIÓN DE OBJETO PERSISTENTE}

\section{persistent object preservation}

s. (POP) Técnica de preservación permanente que asegura que los documentos de archivo digitales permanezcan accesibles gracias a su autodescripción, hecha de manera independiente del equipo o programas de cómputo en los que operen [Archivos]. Véase también: "archivo persistente".

\section{PRESERVACIÓN DE TECNOLOGÍA}

\section{technological preservation}

s. Una de las estrategias de preservación de documentos de archivo digitales que incluye el mantenimiento del equipo y de los programas de la plataforma original en la que los documentos de archivo fueron producidos o la última en la que fueron manifestados en su forma auténtica [Archivos].

\section{PRESERVACIÓN DIGITAL}

\section{digital preservation}

s. El proceso específico para mantener los materiales digitales durante y a través de las diferentes generaciones de la tecnología a lo largo del tiempo, con independencia de los soportes donde residan [Archivos]. Véase también: "preservación de objeto persistente", "preservación de documentos de archivo". 


\section{PRESERVACIÓN PERMANENTE}

\section{permanent preservation}

s. La estabilización y protección física y tecnológica de contenido intelectual de materiales, a fin de mantener una cadena de preservación con el propósito de lograr la preservación continuada, perdurable, estable, duradera, ininterrumpida y sin un final previsible [Archivos].

\section{PRESERVADOR}

\section{preserver}

Véase: "preservador designado de documentos de archivo".

\section{PRESERVADOR DESIGNADO DE DOCUMENTOS DE ARCHIVO}

\section{designated records preserver}

s. Entidad responsable de hacerse cargo de la custodia física y legal, así como de preservar, proteger y asegurar el acceso continuo a copias auténticas de los documentos de archivo de un cierto productor. El papel de este preservador designado debe ser el de un custodio fiable de los documentos de archivo del productor. También se le conoce como preservador designado o "preservador" [Archivos]. Véase también: "archivista”, "sucesor legítimo", "administrador de documentos de archivo", "funcionario de confianza de documentos de archivo".

\section{PRESUNCIÓN DE AUTENTICIDAD}

\section{presumption of autbenticity}

s. Inferencia que afirma la autenticidad de un documento de archivo, extraída de hechos conocidos acerca de la manera en que ese documento fue producido y ha sido mantenido [Archivos]. Véase también: "requisitos de autenticidad", "requisitos de referencia de autenticidad". 
PRIMERA MANIFESTACIÓN DE UN DOCUMENTO DE ARCHIVO

first manifestation of a record

s. La forma documental que tiene un documento de archivo cuando se abre por primera vez al momento de su recepción o justamente después de haber sido capturado (identificado) y declarado como documento de archivo [Archivos]. Véase también: "documento de archivo original".

\section{PRIMITIVIDAD}

primitiveness

Véase: "carácter primitivo".

PRINCIPIO DE ORDEN ORIGINAL

- original order principle

s. Principio de la práctica archivística que establece que cada documento debe mantenerse dentro de un fondo en el orden original que le haya sido dado por su productor [Archivos]. Véase también: "principio de procedencia".

\section{PRINCIPIO DE PROCEDENCIA}

provenance principle

s. Principio de la práctica archivística que establece que cada documento debe estar ubicado en el fondo documental del que procede y en su dependencia de origen [Archivos]. También se le conoce como "principio de proveniencia". Véase también: "principio de orden original".

\section{PRINCIPIO DE PROVENIENCIA}

\section{provenance principle}

Véase: "principio de procedencia". 
PRIORIDAD DE TRANSMISIÓN

\section{priority of transmission}

s. Indicación de la urgencia o importancia que tiene un cierto documento de archivo a ser transmitido [Archivos].

PRIVILEGIOS DE ACCESO

\section{access privileges}

s. Autoridad otorgada a empleados, oficiales, puestos y oficinas dentro de una organización o dependencia o a sus usuarios para acceder a un sistema de mantenimiento de documentos de archivo con diversos propósitos [Archivos-modelo de la cadena de preservación]. Véase también: "restricciones de acceso".

PRIVILEGIOS DE ACCESO EN LA ELABORACIÓN

DE DOCUMENTOS DE ARCHIVO

record-making access privileges

s. Autoridad otorgada a empleados, oficiales, puestos y oficinas dentro de una organización o dependencia para acceder a un sistema de elaboración de documentos de archivo con el fin de compilar, clasificar, registrar, recuperar, anotar o leer información [Archivos-cadena de preservación]. Véase también: "restricciones de acceso".

PRIVILEGIOS DE ACCESO EN EL MANTENIMIENTO

DE DOCUMENTOS DE ARCHIVO

record-keeping access privileges

s. Autoridad otorgada a empleados, oficiales, puestos y oficinas dentro de una organización o dependencia para acceder a un sistema de mantenimiento de documentos de archivo con el fin de compilar, clasificar, registrar, recuperar, anotar, leer, transferir o destruir información [Archivos]. Véase también: "restricciones de acceso". 


\section{PROBATORIO}

\section{probative}

s. (Documento) Evidencia escrita y fehaciente de un acto jurídico completo [Archivos]. Véase también: "disposición”, "narración", "documento de archivo de apoyo".

\section{PROCEDENCIA}

\section{provenance}

s. Las relaciones entre los documentos de archivo y las organizaciones o individuos que los producen, acumulan y usan en el transcurso de sus actividades personales o corporativas [Archivos]. Véase también: "contexto de procedencia", "principio de procedencia".

\section{PROCEDIMIENTO}

\section{procedure}

s. El conjunto de reglas escritas y no escritas y/o los pasos formales para seguirlas que rigen la conducta y etapas para llevar a cabo una cierta transacción [Archivos].

PROCEDIMIENTO DE CREACIÓN

\section{creation procedure}

Véase: "procedimiento de producción".

PROCEDIMIENTO DE PRODUCCIÓN creation procedure

s. El procedimiento que regula la formación de un documento de archivo y/o la forma en que ese documento participa en un cierto acto [Archivos].

\section{PROCEDIMIENTO DOCUMENTAL}

\section{- documentary procedure}

s. El conjunto de reglas establecidas para elaborar un documento de archivo. A mayor estandarización y rigor en 
el procedimiento, mayor fiabilidad de que el documento de archivo sea lo que presume ser [Archivos].

PROCEDIMIENTOS INTEGRADOS DE OPERACIÓN Y DOCUMENTACIÓN

integrated business and documentary procedures

s. Procedimientos operativos y documentales que permiten llevar a cabo la operación encargada al productor de documentos de archivo y que han sido vinculados a un esquema o cuadro de clasificación de archivos para la organización de esos documentos de archivo [Archivoscadena de preservación].

PROCESAMIENTO DE DATOS

\section{data processing}

s. La representación sistemática de una operación o secuencia de operaciones por una o más unidades de procesamiento central en un formato de datos convertido para ser leído por máquinas, a fin de obtener el resultado esperado por el programa de computadora que controla el procesamiento al ser escrito [Informática].

PROCESO

\section{process}

s. La serie y orden de actividades en general que se realizan dentro de cada paso establecido dentro de un procedimiento [Archivos-Duranti, Diplomatics: New Uses for an Old Science, p. 75].

\section{PROCESO DE NEGOCIO}

\section{business process}

s. Serie de normas operativas que rigen la manera en que se lleva a cabo una transacción, trámite u operación [Archivos]. 
PRODUCCIÓN DE DOCUMENTOS DE ARCHIVO

\section{record creation}

create record

s. La primera fase del ciclo de vida de un documento de archivo en la cual es elaborado o recibido y luego separado (apartado, guardado) para futura acción o como referencia, usualmente en un sistema de mantenimiento de documentos de archivo [Archivos]. También se le conoce como "creación de documentos de archivo". Véase también: "documento de archivo producido", "elaboración de documentos de archivo".

\section{PRODUCTOR}

\section{creator}

records creator

s. También llamado productor de documentos de archivo. Una de las cinco personas que debe tener un documento de archivo digital. Es la persona física o jurídica en cuyos fondos existe un documento de archivo; hace (elabora o produce), recibe o acumula documentos de archivo por razones de su mandato, misión, función o actividades. Es quien genera el más alto nivel de agregación al cual los documentos de archivo pertenecen, es decir, los fondos [Archivos]. Véase también: "dependencia controladora", "custodio", "administrador de documentos de archivo".

\section{PRODUCTOS Y FORMATOS DE ACCESO ABIERTO}

\section{open-source products and formats}

\section{open-standard products and formats}

s. Estructuras, procedimientos, programas, formatos y todas aquellas herramientas de programas y aplicaciones de cómputo disponibles de forma abierta y muchas veces sin costo para la creación y descripción de datos. Por lo general son establecidas y mantenidas por un organis- 
mo central, pero a diferencia de los productos propietarios los usuarios no dependen de una empresa privada para el uso o soporte de esos productos [Informática] [Archivos]. Véase también: "arquitectura abierta", "no propietario", "acceso abierto".

\section{PROGRAMA}

\section{program}

s. Conjunto de instrucciones destinadas a ser usadas en una computadora y que permiten a un usuario capturar, procesar o visualizar datos, realizar cálculos y otras acciones tendientes a obtener un resultado específico preestablecido [Informática].

\section{PROPIEDADES SIGNIFICATIVAS}

\section{significant properties}

s. Las características de un objeto de información que deben ser mantenidas a lo largo del tiempo para asegurar su acceso continuado, uso, significación y su capacidad de ser aceptado como evidencia de lo que pretende ser como documento de archivo [Archivos].

\section{PROPIETARIO}

\section{proprietary}

s. Régimen de uso de los programas, formatos, estructuras y otras herramientas que están protegidas bajo una patente $u$ otro registro de propiedad industrial, que pertenecen a una empresa u organización y cuyo uso y licenciamiento está restringido, por lo general bajo pago de derechos, y cuya fuente o tecnología no está disponible al público y no puede ser modificada. Op.: "no propietario" [Informática]. Véase también: "acceso abierto", "productos y formatos de acceso abierto", "arquitectura abierta". 
PROPOSICIÓN DE PRUEBA

\section{e-discovery}

Véase: "e-hallazgo".

\section{PROTOCOLO}

\section{protocol}

s. 1. Elemento interno de la forma documental que se encuentra al inicio de un documento y que usualmente contiene la identificación de las personas que concurren a su formación así como de su contexto jurídico-administrativo y de su ubicación geográfica y temporal [Diplomática] [Archivos-Duranti, Diplomatics: New Uses for an Old Science, p. 142]. Véase también: "introducción", Ontología A. 2. Conjunto de reglas formales que describen la manera de transmitir datos, en especial dentro de una red. Los protocolos de bajo nivel describen elementos eléctricos y físicos que deben ser observados. Los protocolos de alto nivel describen el formateo de los datos, sintaxis de los mensajes, diálogos entre computadoras, conjuntos válidos de caracteres, secuencias, etcétera [Informática].

\section{PUBLICACIÓN}

\section{publication}

s. Información grabada o registrada sobre un soporte físico o electrónico que es producida con el fin de comunicarla y/o diseminarla a un público extenso [Archivos]. 


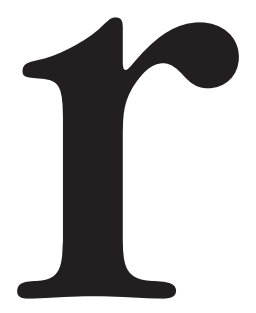

RDF

Acrónimo de Resource Description Framework o "esquema de descripción de recursos".

RECEPCIÓN

accession

Véase: "ingreso".

RECEPTOR

recipient

s. Persona física o jurídica a quien se envía copia de un documento de archivo, además de al destinatario [Archivos].

\section{RECONSTITUIR}

reconstitute

v. Ensamblar y ligar los componentes digitales almacenados de un documento para permitir su reproducción y 
manifestación en forma auténtica [Archivos]. Véase también: "representar".

\section{RECUPERACIÓN DE DATOS}

\section{data restoration}

s. El proceso de restaurar o recuperar datos o documentos de archivo digitales a partir de conjuntos de bits de archivos digitales obsoletos o que han sido dañados, degradados o que han fallado en alguna forma, y sobre los cuales se han aplicado procesos para restaurar la inteligibilidad y coherencia de los datos o elementos recuperados. Se le conoce también como "restauración de datos" o "arqueología digital" [Informática]. Véase también: "estrategia de preservación de documentos de archivo".

RED

\section{network}

s. Sistema de comunicación de datos formado por equipos y programas al efecto. Las redes se clasifican a menudo de acuerdo con su extensión geográfica: "red de área local", "red de área metropolitana" o "red de área extendida". También se les clasifica por el tipo de protocolo utilizado para comunicarse (HTTP, token-ring, etcétera) [Informática].

\section{RED DE ÁREA EXTENDIDA}

\section{wide area network}

s. (WAN) Una red de cómputo y telecomunicaciones que abarca distancias considerables, más allá de lo que puede considerarse área local (más de un kilómetro) [Informática]. Véase también: "red de área local", "red de área metropolitana". 
RED DE ÁREA LOCAL

local area network

s. (LAN) Una red de cómputo y telecomunicaciones que abarca distancias cortas, por lo general en edificios y oficinas contiguos (menos de un kilómetro) [Informática]. Véase también: "red de área extendida”, "red de área metropolitana".

\section{RED DE ÁREA METROPOLITANA}

\section{metropolitan area network}

s. (MAN) Una red de cómputo y telecomunicaciones que abarca distancias considerables, más allá de lo que puede considerarse área extendida, abarcando a toda una ciudad [Informática]. Véase también: "red de área local", "red de área extendida".

\section{RED DE CONMUTACIÓN DE PAQUETES}

\section{packet switching}

s. Protocolo de transmisión de mensajes electrónicos en el cual cada mensaje es dividido en varias porciones (llamadas paquetes) antes de su envío. Cada "paquete" tiene la dirección del destinatario además de los datos en sí y es enviado por separado, en algunos casos siguen rutas distintas hasta su destino. Cuando todos los paquetes llegan son reconstruidos para conformar el mensaje original [Informática].

\section{REFRESCADO}

refreshing

s. El proceso de copiar cierto contenido digital desde un medio digital hacia otro (incluye copiado al mismo tipo de medio). También se le denomina "refresco" [Informática]. Véase también: "conversión", "migración de 
documentos de archivo", "migración transformativa", "refrescado de documentos de archivo".

\section{REFRESCADO DE DOCUMENTOS DE ARCHIVO}

\section{refreshing of records}

s. El proceso de volver a copiar documentos de archivo digitales durante el curso normal de las actividades de la organización; busca asegurar su continua y futura accesibilidad dejando intacto su contenido intelectual. Este proceso se efectúa cuando el medio o soporte se considera obsoleto o degradado. Se le llama también refresco de documentos de archivo [Archivos]. Véase también: "conversión", "migración de documentos de archivo", "migración transformativa".

\section{REFRESCO}

refresbing

Véase: "refrescado".

\section{REGISTRO DE ESQUEMAS DE METADATOS}

\section{metadata schema registry}

s. Una fuente autorizada que puede utilizarse para catalogar, describir, documentar y analizar esquemas de metadatos y sus variantes [Archivos].

\section{REGISTRO DE METADATOS}

\section{metadata registry}

s. 1. Una fuente autorizada como repositorio para nombres, semántica y sintaxis de uno o varios esquemas. 2 . Un programa que usa lenguajes de metadatos en formato legible por máquina para facilitar el uso de esos lenguajes tanto a personas como a máquinas [Archivos]. 


\section{REGISTRO DE PROTOCOLO}

\section{protocol register}

s. Un tipo de registro que consigna los atributos de identificación de los documentos de archivo entrantes, salientes e internos, especificando la acción tomada con ellos. Se le llama también registro de correspondencia [Archivos].

REGLA

rule

s. Una instrucción con autoridad emitida por la persona competente acerca de lo que puede o no hacerse en cierta situación [Diccionario General]. Véase también: "mejores prácticas", "directiva", "lineamiento", "política", "estándar".

\section{REGLA SEMÁNTICA}

\section{semantic rule}

s. Una regla que rige los significados o interpretaciones de símbolos o elementos dentro de un objeto [Informática]. Véase también: "regla sintáctica".

\section{REGLA SINTÁCTICA}

\section{- syntactic rule}

s. Una regla que rige la forma en que los símbolos o los elementos dentro de un objeto pueden ser ordenados y/o utilizados [Informática]. Véase también: "regla semántica".

\section{REGLAS DE NEGOCIO}

\section{business process}

s. La serie de reglas que gobierna el orden y la manera en que una transacción es llevada a término [Diccionario General]. 


\section{REINGENIERÍA DE SOFTWARE}

\section{software re-engineering}

s. La transformación sistemática de programas y aplicaciones de cómputo existentes o de sistemas completos hacia nuevas formas con propósito de mejorar su operación, capacidad, funcionalidad, interoperabilidad, rendimiento, etcétera [Informática]. Véase también: "compatibilidad retrospectiva", "conversión", "estrategia de preservación de documentos de archivo", "migración transformativa".

\section{RENDICIÓN DE CUENTAS}

\section{accountability}

s. La obligación que se tiene de responder por las acciones y/o obligaciones ante un contralor o supervisor [Diccionario General].

\section{RENDICIÓN DE CUENTAS (ADMINISTRATIVA)}

\section{administrative accountability}

s. La lista de responsabilidades que adquieren las autoridades y funcionarios del servicio público dedicadas a tareas archivísticas. Involucra el desarrollo, implementación y seguimiento de procedimientos para llevar a cabo las acciones pertinentes así como documentarlas para asegurar que todo se hace de acuerdo a las reglas y en secuencia adecuada, de tal forma que esos administradores puedan dar cuenta exacta y oportuna de todo lo que se ha hecho bajo su gestión [Archivos].

\section{RENDICIÓN DE CUENTAS (HISTÓRICA)}

\section{bistorical accountability}

s. La obligación y necesidad que se tiene de dar y recibir explicación y entendimiento de una generación a otra. Los grupos de individuos a menudo derivan su cohesión, 
autoridad de sus actos y legitimidad a partir del entendimiento y evaluación de su pasado [Archivos].

RENDICIÓN DE CUENTAS (PÚBLICA)

\section{public accountability}

s. La obligación a rendir cuentas públicamente acerca de hechos de la gestión de un funcionario, así como el derecho por parte de los ciudadanos de conocer esos hechos con el fin de servir a la transparencia y al debate público de los ciudadanos y quienes fueron elegidos como representantes [Gobierno].

\section{REPOSITORIO INSTITUCIONAL}

\section{institutional repository}

s. Conjunto de servicios e instalaciones ofrecidos por una organización a los miembros de su comunidad para el manejo y diseminación de materiales digitales producidos por la organización y sus miembros [Archivos].

\section{REPRESENTAR}

render

v. 1. Generar y/o ensamblar los componentes de uno o varios objetos digitales para permitir su manifestación en una forma íntegra y comprensible. 2. Dibujar un objeto del mundo real de diversas formas a partir de un modelo matemático [Diccionario General]. Véase también: "manifestar", "reconstituir".

\section{REPRODUCCIÓN}

\section{reproduce}

s. El proceso de hacer una copia [Archivos-Duranti, Eastwood \& Macneil, Preservation of the Integrity of Electronic Records, p. 13]. 
Requerimientos para pruebas...

REQUERIMIENTOS PARA PRUEBAS DE AUTENTICIDAD

Véase: "requisitos de referencia de autenticidad".

REQUISITO

requirement

s. Demanda, necesidad, requerimiento, restricción o parámetro que debe ser satisfecho o cubierto, por lo general dentro de un cierto periodo y condiciones [Diccionario Generall. Véase también: "requisitos de autenticidad", "requisitos básicos de autenticidad", "requisitos de referencia de autenticidad", "acatamiento".

\section{REQUISITOS DE AUTENTICIDAD}

\section{autbenticity requirement}

s. Especificación de los elementos de forma y contexto que necesitan ser preservados para mantener la autenticidad de cierto tipo de documento de archivo digital [Archivos]. Véase también: "requerimientos para pruebas de autenticidad", "requisitos básicos de autenticidad", "presunción de autenticidad".

\section{REQUISITOS BÁSICOS DE AUTENTICIDAD}

\section{baseline autbenticity requirements}

s. Condiciones mínimas necesarias para permitir al preservador avalar la autenticidad de las copias de los documentos de archivo digitales de un productor que se encuentran bajo su custodia [Archivos]. Véase también: "requisitos de autenticidad", "requerimientos para pruebas de autenticidad".

\section{REQUISITOS DE REFERENCIA DE AUTENTICIDAD}

\section{benchmark authenticity requirements}

s. Condiciones que sirven al preservador como base para la evaluación acerca de la autenticidad de los documen- 
tos de archivo digitales durante la valoración [Archivos]. Véase también: "requisitos de autenticidad", "requisitos básicos de autenticidad", "presunción de autenticidad".

\section{REQUISITOS DEL MARCO DE REFERENCIA}

framework requirements

s. Normatividad que guía el diseño del sistema de producción, mantenimiento y preservación permanente de documentos de archivo [Archivos-cadena de preservación].

RESPALDAR

back up

v. Hacer una copia de un archivo de datos con el fin de recuperarlo en caso de falla dentro de un sistema [Informática].

\section{RESPALDO}

backup

s. Una copia de un archivo de datos hecha con el fin de recuperarlo en caso de falla dentro de un sistema [Informática].

\section{RESTAURACIÓN DE DATOS}

Véase: "recuperación de datos".

\section{RESTRICCIONES DE ACCESO}

\section{access restrictions}

s. También llamado acceso restringido. Autoridad especial otorgada a una persona, oficial, puesto $u$ oficina dentro de una organización o dependencia para leer un documento de archivo [Archivos]. Véase también: "privilegios de acceso". 


\section{RETENCIÓN}

retention

s. Tiempo durante el cual un documento de archivo es conservado para su utilización dentro de la organización y que es preestablecido en una "tabla de retención". Véase también: "disposición".

\section{REUTILIZACIÓN}

repurposing

s. El proceso de tomar contenido de un medio (libro, televisión, periódico, radio) y reempaquetarlo para su uso en otro medio, como la web [Diccionario GeneralSociety of American Archivists, A Glossary of Archival \& Records Terminology]. 


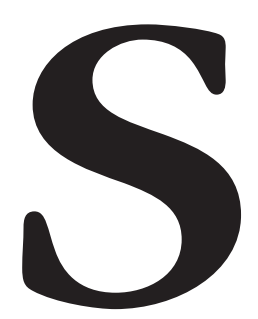

SALUTACIÓN

salutation

s. Uno de los elementos internos de la forma documental que consiste en una forma de saludo que aparece sólo en cartas, por lo general después de la inscripción [Archivos-Duranti, Diplomatics: New Uses for an Old Science, p. 144]. Véase también: Ontología A.

SALVAR

save

v. Guardar o fijar un objeto digital en un medio de almacenamiento digital no-volátil [Informática].

\section{SEGURIDAD INFORMÁTICA}

\section{information security}

s. El proceso de establecer y observar un conjunto de estrategias, políticas, técnicas, reglas, guías, prácticas y procedimientos tendientes a prevenir, proteger y resguardar de daño, alteración o sustracción los recursos informáticos de una organización y que administren el 
riesgo al garantizar en la mayor medida posible el correcto funcionamiento ininterrumpido de esos recursos [Informática].

\section{SELECCIÓN}

\section{selection}

s. El conjunto de las estrategias de valoración, los procedimientos de supervisión, las reglas de disposición, los procedimientos dentro del sistema de preservación permanente, las herramientas y los mecanismos necesarios para realizar una separación de los documentos de archivo.

\section{SELLO}

\section{seal}

s. Pieza de cera, plomo, madera u otro material sobre el que ha sido grabado un cierto diseño, mismo que puede ser transferido al aplicarlo sobre un documento. Originalmente era usado como un medio de autenticación del autor de un documento de archivo y de éste en sí mismo [Archivos]. Véase también: "sello electrónico".

\section{SELLO DE TIEMPO}

\section{timestamp}

s. Certificación de un tercero confiable de que un cierto documento de archivo fue recibido en una fecha y/o hora determinadas [Archivos-InterPARES, "InterPARES Template for Analysis of Electronic Records", p. 194].

\section{SELLO DIGITAL DE TIEMPO}

\section{digital timestamp}

s. También conocido como sellado de tiempo. Es un código binario adjuntado por una autoridad a un documento 
de archivo digital que indica la fecha y hora en la cual ocurrió cierto evento sobre el documento, tal como la producción, la recepción, la lectura, la modificación o la eliminación del mismo [Archivos].

\section{SELLO ELECTRÓNICO}

\section{- electronic seal}

s. Técnica computacional, por lo general consistente en una marca o secuencia digital, que al ser intrínsecamente asociada a un documento de archivo opera funcionalmente como un sello o firma sobre el mismo con el fin de demostrar la autenticidad del remitente, la naturaleza inalterada de su contenido, o para proteger la confidencialidad de éste evitando accesos no autorizados. Es una variante de la firma electrónica. También se le conoce como sello digital [Archivos].

\section{SEPARAR}

\section{set aside}

v. Declarar un documento de archivo y retenerlo -apartarlo, guardarlo- para futura referencia o uso, generalmente en un sistema de mantenimiento de documentos de archivo [Archivos].

SERIE

series

Véase: "serie de documentos de archivo".

\section{SERIALIZAR}

\section{serialize}

v. Salvar temporalmente un objeto digital en un medio de almacenamiento localizado en una ubicación remota e independiente con objeto de que pueda ser transmitido o almacenado posteriormente en otro lugar [Informática]. 


\section{SERIE DE DOCUMENTOS DE ARCHIVO}

\section{record series}

s. Expedientes (dossier), unidades de archivos o documentos individuales que fueron acomodados de acuerdo con un sistema de clasificación archivístico o que han sido mantenidos como una unidad por ser resultado de la misma acumulación o proceso de organización archivística, la misma función o la misma actividad, y que tienen una forma particular o alguna otra relación proveniente de su producción, recepción o uso. También se le conoce simplemente por "serie" [Archivos-Society of American Archivists, A Glossary of Archival \& Records Terminology]. Véase también: "expediente", "carpeta", "fondo", "ítem".

\section{SEUDOORIGINAL}

\section{pseudo-original}

s. Una copia de un documento de archivo en la cual se trata de imitar al original hasta el último detalle con el fin de hacer pasar la copia como original [Archivos]. Véase también: "copia auténtica", "copia conformada", "copia en forma de original", "copia imitativa", "copia simple", Ontología B.

SGML

Acrónimo de "Standard Generalized Markup Language" o "Lenguaje de Marcado Estándar Generalizado".

\section{SIGNO ESPECIAL}

\section{special sign}

s. Uno de los elementos externos de la forma documental que consiste en un signo, señal o marca del escritor o 
de los firmantes, así como de las cancillerías y oficinas involucradas en la compilación, recepción o ejecución del documento [Diplomática]. Véase también: Ontología A.

\section{SÍMBOLO}

symbol

s. Un carácter, marca, imagen, forma, característica u otro objeto usado para representar o denotar algo por asociación, convención o parecido [Diccionario General].

SISTEMA

system

s. Conjunto organizado, integrado y detallado de métodos, políticas, procedimientos, recursos, rutinas, reglas y otras herramientas implementadas para llevar a cabo una actividad específica, realizar una tarea o resolver un problema [Diccionario General].

\section{SISTEMA ANALÓGICO}

\section{analogue system}

s. Cualquier sistema que maneje datos u objetos analógicos, lo contrario de un sistema digital [Ciencias].

SISTEMA DE ADMINISTRACIÓN DE DOCUMENTOS DE ARCHIVO

Electronic Records Management System

Véase: "sistema de gestión de documentos de archivo".

SISTEMA DE CIFRADO

\section{cryptographic system}

\section{cryptosystem}

s. Un sistema o proceso informático que involucra cifrado o encriptado de datos [Informática]. 
SISTEMA DE CIFRADO CON LLAVE PÚBLICA

\section{public key cryptosystem}

s. (PKC) Un sistema de cifrado o encriptado de datos que utiliza dos llaves o contraseñas: una pública, conocida por todo mundo y que es usada por el emisor del mensaje para cifrarlo o encriptarlo, y una privada, conocida únicamente por el receptor del mensaje y que le sirve para descifrarlo o desencriptarlo. Cualquier otro par de llaves no funcionará [Informática].

\section{SISTEMA DE DESCRIPCIÓN ARCHIVÍSTICO}

\section{archival description system}

s. Conjunto de instrumentos descriptivos que proporcionan el control físico e intelectual de los documentos de archivo en una institución o programa archivísticos. Incluye, sin ser limitativo, guías, inventarios, índices y ubicación topográfica [Archivos].

\section{SISTEMA DE DOCUMENTOS DE ARCHIVO}

\section{records system}

s. El conjunto de reglas que rigen la elaboración y mantenimiento de documentos de archivo, de acuerdo a la función de administración de documentos de archivo de un productor, así como las herramientas y mecanismos utilizados para implementar ese conjunto [Archivos].

\section{record-making system}

s. El conjunto de reglas que controlan el proceso de formación y producción de documentos de archivos, así como las herramientas y mecanismos utilizados para implementar esas reglas [Archivos-cadena de preservación]. Véase también: "documento de archivo producido", "producción de documentos de archivo", "cadena de preservación". 
SISTEMA DE GESTIÓN DE DOCUMENTOS DE ARCHIVO

\section{Electronic Records Management System}

s. Proviene de Electronic Records Management System (ERMS). Conjunto de reglas que rigen la producción, almacenamiento, uso, mantenimiento y disposición de documentos de archivo de un productor, además de las herramientas y mecanismos usados para implementar esas reglas [Archivos]. Nótese que la gestión archivística abarca la elaboración, mantenimiento y preservación de documentos de archivo. Se le conoce también como "sistema de administración de documentos de archivo".

\section{SISTEMA DE INFORMACIÓN}

\section{information system}

s. Una estructura basada en programas y equipos de cómputo que tiene como principal característica su capacidad de ofrecer información a sus usuarios [Informática].

\section{SISTEMA DE INFORMACIÓN GEOGRÁFICO}

\section{geographic information system}

s. (GIS) Un sistema de información basado en su equipo, programas, información geográfica, procedimientos y personal concebidos para facilitar la captura, almacenamiento, mantenimiento, manipulación, análisis, búsqueda y recuperación eficientes de datos espacialmente referenciados (geoespaciales), provenientes de una amplia variedad de fuentes en una amplia variedad de formatos -mapas, gráficas, fotografías, datos de sensores, datos tabulares, textos, etcétera-, proveyendo así un vínculo automático entre los datos geoespaciales y los metadatos descriptivos acerca de ellos usados en sistemas de coordenadas (latitud, longitud, altitud, etcétera) [Informática]. 
SISTEMA DE MANTENIMIENTO DE DOCUMENTOS DE ARCHIVO recordkeeping system

s. Conjunto de reglas que rigen el almacenamiento, uso, mantenimiento y disposición de documentos de archivo y/o información acerca de ellos, así como las herramientas y mecanismos usados para implementar esas reglas [Archivos]. Véase también: "cadena de preservación".

SISTEMA DE PRESERVACIÓN

\section{preservation system}

Véase: "sistema de preservación de documentos de archivo".

\section{SISTEMA DE PRESERVACIÓN ARCHIVÍSTICA}

\section{archival preservation system}

Véase: "sistema de preservación de documentos de archivo".

\section{SISTEMA DE PRESERVACIÓN DE DOCUMENTOS DE ARCHIVO}

\section{records preservation system}

s. Conjunto de principios, políticas, reglas y estrategias, así como las herramientas y mecanismos utilizados para implementarlas y que han sido adoptadas por una institución o programa archivísticos, para mantener a largo plazo los componentes digitales y su información relacionada así como para reproducir documentos de archivo auténticos y/o agregaciones de ellos que hayan sido producidos mediante la interpretación de controles externos, aplicando éstos últimos a los documentos de archivo seleccionados para su preservación. También se le conoce como "sistema de preservación", "sistema de preservación archivística", "sistema de preservación permanente" [Archivos-cadena de preservación]. Véase también: "cadena de preservación", "archivo persistente". 
SISTEMA DE PRESERVACIÓN PERMANENTE

\section{permanent preservation system}

Véase: "sistema de preservación de documentos de archivo".

\section{SISTEMA DE RECUPERACIÓN}

\section{retrieval system}

s. Conjunto de reglas que rigen la búsqueda y localización de documentos de archivo dentro de un sistema de mantenimiento documental, así como las herramientas y mecanismos utilizados para implementar dichas reglas [Informática].

\section{SISTEMA DE REGISTRO}

\section{registry system}

s. Sistema que controla la producción, mantenimiento y uso de documentos de archivo activos y semiactivos por medio del uso de registros formales, listas e índices [Archivos-Society of American Archivists, A Glossary of Archival \& Records Terminology].

\section{SISTEMA DE SELECCIÓN}

\section{selection system}

s. Las estrategias de valoración, procedimientos de monitoreo y reglas de disposición documental así como los procedimientos dentro de un sistema de preservación permanente de documentos de archivo, junto con las herramientas y mecanismos necesarios para efectuar la selección de esos documentos [Archivos].

\section{SISTEMA DIGITAL}

\section{digital system}

s. Cualquier sistema que maneja datos binarios y/o numéricos en contraste con un sistema analógico [Informática]. 
SISTEMA ELECTRÓNICO (DE DOCUMENTOS DE ARCHIVO) electronic system

s. Cualquier sistema electrónico que produce, procesa o almacena documentos de archivo por medio de una computadora. También se le conoce como sistema automatizado de información [Gobierno].

\section{SISTEMA EXPERIENCIAL}

\section{experiential system}

s. Un sistema que sumerge a su usuario en experiencias sensoriales. También llamado de realidad virtual [Diccionario General].

\section{SISTEMA INTERACTIVO}

\section{interactive system}

s. Un sistema tal que, a cada entrada que proporciona un usuario, responde al instante con una acción o respuesta, en función de cierta inteligencia artificial agregada en forma de preguntas y datos preestablecidos [Diccionario General].

SISTEMA JURÍDICO

juridical system

s. Grupo social organizado sobre la base de un sistema de reglas y normas y que incluye tres componentes: el grupo social, el principio organizacional del grupo social y el sistema de reglas vinculantes reconocidas por el grupo social [Diccionario General].

SOPORTE

\section{support}

s. Material físico o sustancia sobre la cual la información se registra o almacena. También se le conoce como "medio" o "medio escriptorio" [Informática]. 
a. Evidencia constituida de una actividad jurídicamente relevante [Derecho].

STANDARD GENERALIZED MARK-UP LANGUAGE

Véase: "Lenguaje de Marcado Estándar Generalizado".

SUCESOR LEGÍTIMO

- legitimate successor

s. Persona u organización que adquiere ciertos acervos archivísticos y las funciones asociadas a éstos, o el preservador designado de documentos de archivo [Archivos]. Véase también: "control administrativo", "dependencia controladora".

SUJETO

\section{subject}

s. Uno de los elementos internos de la forma documental que comprende un símbolo que identifica a una o más de las personas involucradas en la compilación, recepción o ejecución de un documento de archivo [Diplomática].

\section{SUPRASCRIPCIÓN}

\section{superscription}

s. Parte de la forma documental de un documento de archivo que contiene la mención del nombre del autor del documento y/o su acción o asunto. A veces toma la forma de la intitulación y a veces coexiste con la intitulación [Diplomática] [Archivos-Duranti, Diplomatics: New Uses for an Old Science, p. 143]. Véase también: Ontología A. 


\section{SUSCRIBIR}

subscribe

v. El acto de avalar un documento firmándolo o poniendo el nombre propio en lugar al efecto [Gobierno-Black's Law Dictionary].

\section{SUSCRIPCIÓN}

\section{subscription}

s. Parte de la conclusión de un documento de archivo; contiene la firma o identificación del nombre del responsable del documento de archivo al final del mismo. 


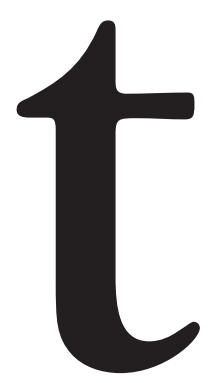

TABLA CRUZADA crosswalk

s. Una tabla que representa un mapeo semántico de campos o elementos de datos en un estándar de metadatos para campos o elementos de datos en otro estándar que tiene una función o significado similar [Archivos].

TABLA DE CADUCIDADES

Véase: "tabla de retención".

\section{TABLA DE RETENCIÓN}

\section{retention schedule}

records retention schedule

s. Documento que describe series o clases de documentos de archivo y especifica sus términos de retención (guardado en el archivo) y de disposición (destrucción o transferencia a un destino final), las fechas o eventos que los detonan así como las acciones a realizar al término 
de ese lapso [Archivos]. También se le conoce como "catálogo de disposición documental" y "tabla de caducidades".

\section{TECNOLOGÍA OBSOLETA}

obsolete technology

s. Los desarrollos tecnológicos (equipos, dispositivos, programas, formatos, etcétera) que llegan a un estado que ya se considera anticuado, poco adecuado a las circunstancias actuales o que ha caído en desuso o está cerca de ello [Diccionario General].

TEMA

subject line

Véase: "asunto".

TENENCIA DE DOCUMENTOS DE ARCHIVO

recordkeeping

Véase: "mantenimiento de documentos de archivo".

\section{TERCERO DE CONFIANZA}

trusted third party

s. Cualquier tercera persona -física o jurídica- que no se considere parte de los hechos o actos consignados en un documento y por tanto no le conciernen directamente [Archivos]. Véase también: "custodio fiable", "funcionario de confianza de documentos de archivo".

\section{TÉRMINOS Y CONDICIONES DE TRANSFERENCIA}

\section{terms and conditions of transfer}

s. Instrumentos formales que identifican en términos archivísticos y tecnológicos el conjunto de documen- 
tos de archivo a ser transferido, además de su información relevante y la identificación de medios, formatos, plazos y actores responsables de la transferencia [Archivos].

\section{TESTIMONIO DE TERCEROS}

\section{bearsay rule}

s. Previsión legal que excluye testimonio basado en afirmaciones de terceras personas en vez de experiencias o vivencias personales [Archivos].

TEXTO

\section{text}

s. 1. Conjunto de palabras, números y caracteres especiales que conforman un significado a través del lenguaje [Diccionario General]. 2. Uno de los elementos internos de la forma documental el cual consiste en la sección central de un documento que contiene la acción e incluye las consideraciones y circunstancias que le dieron origen, así como las condiciones relativas a su cumplimiento Véase también: "cuerpo" [Diplomática] [Archivos-Duranti, Diplomatics: New Uses for an Old Science, p. 142].

\section{TEXTO CIFRADO}

\section{cipbertext}

s. Resultado de datos o información transformados por medio de un proceso de cifrado o encriptado para hacerlos ininteligibles a extraños. Sólo quien conoce la clave puede volver a descifrarlo [Informática]. Véase también: "codificación críptica".

\section{TEXTO PLANO}

\section{plain text}

s. Texto u otro dato similar que no tiene formateo ni cifrado o encriptado [Informática]. 
TIPO DE DATOS

data type

s. La representación de información digital conforme a especificaciones preestablecidas. Ejemplo: texto plano, HTML, TIFF, etcétera [Informática].

\section{TIPO DE ENTIDAD}

\section{entity type}

s. La clase o variedad de entidad identificada, descrita o mencionada por un esquema de metadatos; por ejemplo: fondos, documentos de archivo, agentes u organizaciones gestoras de documentos, entre otros [Archivos].

TÍTULO

title

s. Uno de los elementos internos de la forma documental que comprende la indicación de la acción, tema o materia del documento, por lo general en forma de "intitulación" o en lugar de ésta [Diplomática].

TRÁMITE

Véase: "transacción".

\section{TRANSACCIÓN}

transaction

s. Acción o acciones interconectadas y sucesivas en las que interviene más de una persona y por la cual la relación entre esas personas resulta modificada. También se le conoce como "trámite" [Archivos-UBC School of Library, Archival and Information Studies (SLAIS) Glossary]. 
TRANSFERENCIA DE FONDOS

\section{accrual}

s. También llamado "incremento de fondos" o "acumulación de fondos". La adquisición o traslado de nuevos fondos archivísticos de un productor hacia un preservador en adición a los fondos de ese productor que el preservador ya tenía en custodia [Archivos].

\section{TRANSPARENCIA}

\section{public accountability}

s. El derecho que tienen los ciudadanos a recibir información acerca de hechos realizados por los funcionarios públicos para que puedan ser debatidos entre los ciudadanos y sus representantes [Gobierno].

\section{TRAZA DE AUDITORÍA}

\section{audit trail}

s. Documentación de las acciones e interacciones de los documentos de archivo dentro de un sistema electrónico de mantenimiento de documentos de archivo; lleva registro de todos los accesos al sistema al momento que ocurren. También se le conoce simplemente como traza [Archivos] [Informática].

\section{TRANSMISIÓN}

\section{transmission}

s. Desplazamiento de un documento de archivo a lo largo del tiempo y del espacio, puede ser de una persona u organización a otra, o de un sistema a otro [Archivos]. 



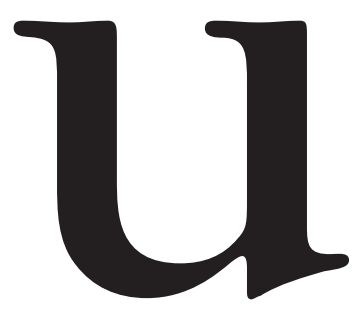

\section{UNICODE}

s. Código estándar mundial para representar con un código binario de 16 bits todos los caracteres de texto de todos los idiomas existentes y vivos en la actualidad, con miras a ser utilizados de forma estándar en las computadoras y dispositivos actuales [Informática]. Véase también: "American Standard Code for Information Interchange", "Universal Character Set Transformation Format 8".

\section{UNIDAD ARCHIVÍSTICA}

archival unit

s. Cualquier agrupación de documentos de archivo que comprende un fondo, según se estableció durante el proceso de arreglo archivístico. Una unidad archivística puede ser un fondo, una serie, un expediente, una unidad (documento de archivo simple) o variaciones de ésta, dependiendo de los estándares institucionales. Una unidad 
puede estar dividida en subunidades para propósitos de descripción archivística. La unidad mínima es la unidad o documento de archivo simple y por tanto es indivisible [Archivos].

\section{UNIDAD CENTRAL DE PROCESO}

\section{central processing unit}

s. Componente de los equipos de cómputo que posee los circuitos principales (procesador, buses, tarjetas, etcétera) que permiten el proceso de los programas y aplicaciones ejecutados en la computadora [Informática].

\section{UNIDAD DE AGREGACIÓN ARCHIVÍSTICA}

\section{aggregate archival unit}

s. Una entidad de archivo compuesta por múltiples y variados fondos o series documentales [Archivos].

\section{UNIFORM RESOURCE LOCATOR}

Véase: "localizador uniforme de recursos web".

\section{UNIVERSAL CHARACTER SET TRANSFORMATION FORMAT 8}

S. (UTF-8) Un esquema derivado del código ASCII para extender la cantidad de caracteres que este último podía representar, de 128 a 256 caracteres. Es también la manera estándar de codificar valores unicode en sólo 8 bits [Informática].

UDF

Acrónimo de "Universal Disk Format" o "Formato Universal de Disco".

URI

Véase: "identificador uniforme de recursos". 


\section{UNIVERSAL RESOURCE LOCATOR}

Véase: "localizador uniforme de recursos web".

\section{USUARIO EXTERNO}

external user

s. Usuario secundario o alternativo al que se le permite el acceso a los documentos de archivo de un productor a través de un sistema en línea de mantenimiento de documentos de archivo; por ejemplo, periodistas o investigadores académicos [Archivos].

UTF-8

Véase: "Universal Character Set Transformation Format 8". 


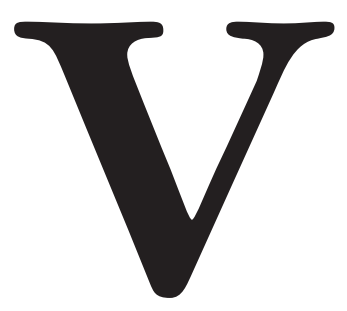

\section{VARIABLE CONTINUA}

continuous variable

s. Las entidades y relaciones cuentan con propiedades o atributos, entre ellos pueden ser continuos o discretos. Los atributos continuos pueden tomar cualquier valor posible dentro del rango de una variable -los números reales-. Por ejemplo, unidades de medida que permiten fracciones: 8.2 metros, 9.25 litros, 7.375 gramos, etcétera. Para la representación de datos pueden usarse variables continuas o discretas; por ejemplo, la música puede ser representada en forma de ondas mecánicas, eléctricas o magnéticas. La forma y valor de una onda es una representación de variables continuas, donde a cada momento el valor de la variable que representa a la onda va cambiando una fracción. Los dispositivos, datos, formatos o soportes analógicos siempre representan su contenido con variables continuas. Véase también: "analógico", "variable discreta", "documento analógico". 


\section{VARIABLE DISCRETA}

\section{discrete variable}

s. Las entidades y relaciones cuentan con propiedades o atributos, entre ellos pueden ser continuos o discretos. Discreto tiene aquí el sentido de diferenciado, individual, no continuo. Los atributos discretos no pueden tomar todos los valores posibles dentro del rango de la variable, sólo pueden tomar valores preestablecidos en ese rango dentro de los números enteros. Por ejemplo, la fecha en que ha de realizarse un evento: no hay fracciones y los días para un cierto mes forman un conjunto predeterminado. Para la representación de datos pueden usarse variables continuas o discretas, como por ejemplo, la música puede ser representada en forma de dígitos que van dando valores aproximados de una onda en un cierto momento. La secuencia de dígitos que van representando la forma de la onda es una secuencia de valores discretos. Los dispositivos, datos, formatos o soportes digitales siempre representan su contenido con variables discretas, esto es, dígitos. Véase también: "digital", "variable continua", "documento digital".

\section{VALOR HISTÓRICO}

\section{bistorical value}

s. El mérito, utilidad, interés, atractivo, importancia, estimación, beneficio o provecho que tiene un documento de archivo para fines históricos [Archivos].

\section{VALORACIÓN}

\section{appraisal}

s. El proceso de determinar el valor de los documentos de archivo con el propósito de establecer su periodo de retención y disposición (destrucción o transferencia), así como los términos y condiciones de su transferencia des- 
de el productor hacia el preservador [Archivos]. Este término se usa en España, México, Centroamérica, Colombia y Perú; no así en Argentina, Uruguay y Brasil donde el término empleado es "evaluación".

VARIABILIDAD VINCULADA (ACOTADA, LIMITADA)

- bounded variability

s. Variaciones o cambios conocidos y estables en la forma y/o contenido de un documento de archivo digital que están limitados y controlados por reglas fijas, de tal forma que la misma pregunta, solicitud o interacción (query) siempre genera el mismo resultado [Archivos]. Véase también: "forma fija", "fijeza", "estable".

\section{VERACIDAD}

\section{truthful}

s. Calidad de un documento de archivo de que su contenido concuerde con el estado real de su asunto. Junto con "precisión", "corrección" y "pertinencia" es un componente de la "exactitud" [Archivos].

\section{VERIFICACIÓN DE AUTENTICIDAD} verification of autbenticity

s. El proceso de efectuar una correspondencia entre hechos conocidos acerca de un cierto documento de archivo y los contextos en los que fue producido y mantenido, con propósito de establecer la autenticidad del documento de archivo [Archivos].

\section{VERSIÓN}

\section{version}

s. Alguna de las variantes de un trabajo intelectual, creada probablemente con el propósito de usar esa copia en lugar del original mismo [Diccionario General]. 
VERSIÓN AUTORIZADA

autboritative version

s. La versión de un documento de archivo que es considerada por su productor como su documento de archivo oficial y que por lo general ha sido sometida a controles procedimentales a los que no están sujetas otras instanciaciones [Archivos].

\section{VERSIÓN DEL DOCUMENTO DE ARCHIVO}

\section{record version}

s. Una de las formas en la cual un documento de archivo es emitido (borrador o completo) [Archivos]. Véase también: Ontología B.

\section{VIABILIDAD DE LA PRESERVACIÓN}

feasibility of preservation

s. Establecimiento de los componentes digitales que confieren identidad y aseguran la integridad de los elementos que se desean preservar, esta preservación es posible dadas las capacidades presentes y futuras [Archivos-Eastwood, "Appraising digital records for long-term preservation”, p. 205].

\section{VIDEODISCO DIGITAL}

digital videodisc

s. También conocido como DVD por Digital Video Disc. Soporte óptico digital circular capaz de almacenar de 4.7 a 8.5 Gigabytes de datos digitales sobre dos pistas o ranuras continuas, microscópicas, en forma de espiral, que se graban y leen sobre una o dos de sus superficies por medio de un rayo láser. Sus especificaciones lógicas de formato digital están establecidas en la especificación denominada Formato de Disco Universal (UDF por Universal Disk Format). También se le conoce como disco 
digital versátil [Informática]. Véase también: "disco compacto"; "almacenamiento no-volátil", "disco óptico".

\section{VÍNCULO ARCHIVÍSTICO}

archival bond

s. La red de relaciones que vincula a cada documento de archivo con los previos y los subsecuentes que intervienen en la misma actividad o agregación. Tiene tres características: 1) tiene origen (existe cuando un documento de archivo es elaborado o recibido y separado), 2) es necesario (existe para cada documento de archivo) y 3) es determinado (está definido por el propósito del documento de archivo) [Archivos]. Véase también: Ontología A. 


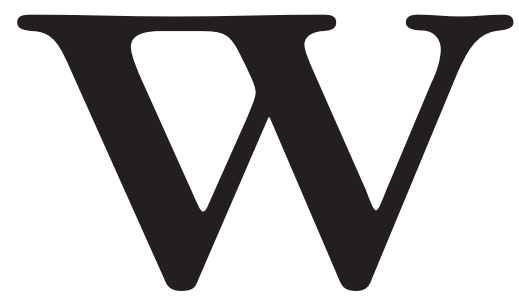

WAN

Acrónimo de Wide Area Network.

Véase: "red de área extendida". 


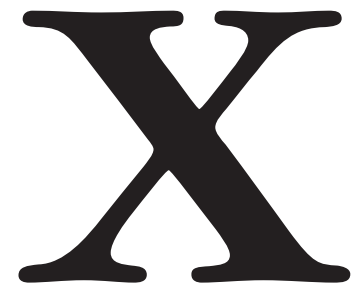

XML

Acrónimo de "Extensible Markup Language" o "Lenguaje de Marcado Extendido". 
BIBLIOGRAFÍA

\section{REFERENCIAS DEL Glosario}

AGLS (Australia Government Locator Service)-State Government of Victoria, Australia, AGLS Victoria: Metadata Implementation Manual. Disponible en: http://www.egov.vic.gov.au/website-practice/metadata/australian-government-locator-serviceagls-/agls-victoria-metadata-implementation-manual.html

Black's Law Dictionary, 2a ed., St. Paul, Min.: West Group, 2012. Disponible en: http://thelawdictionary.org/

Duranti, Luciana, Diplomatics: New Uses for an Old Science, Scarecrow Press, 1998, 186 pp. ISBN: 0810835282. Las referencias del glosario han sido tomadas de esta versión original en inglés; no obstante, existe también una traducción al español: Duranti, Luciana, Diplomática: Usos nuevos para una antigua ciencia, Carmona, Sevilla: S\&C Ediciones, 1996. ISBN: 84-920332-5.

Duranti, Luciana; Eastwood, Terry \& MacNeil, Heather, Preservation of the Integrity of Electronic Records, Dordretch, Nederland: Kluwer Academic Publ., 2002. ISBN: 1-4020-0991-7.

Duranti, Luciana \& Preston, Randy, "Introduction", International Research on Permanent Authentic Records in Electronic Systems (InterPARES) 2: Experiential, Interactive and Dynamic Records, Luciana Duranti y Randy Preston (eds.), Padova, Italia: Associazione Nazionale Archivistica Italiana, 2008. Disponible en: http://www.interpares.org/display_file. cfm?doc=ip2_book_introduction.pdf

Duranti, Luciana \& Thibodeau, Kenneth, "The Concept of Record in Interactive, Experiential and Dynamic Environments: the View of InterPARES", en Archival Science, vol. 6, núm. 1, marzo, 2006, pp. 13-68. Disponible en: http://link.springer. com/article/10.1007\%2Fs10502-006-9021-7 
Duranti, Luciana \& MacNeil, Heather, "The protection of the integrity of electronic records: An overview of the UBC-MAS Research Project", en Archivaria, vol. 42, 1996, pp. 46-67.

Eastwood, Terry, "Appraising digital records for long-term preservation”, en Data Science Journal, vol. 3, núm. 30, diciembre, 2004.

Eastwood, Terry; Hofman, Hans \& Preston, Randy, "Part FiveModeling Digital Records Creation, Maintenance and Preservation: Modeling Cross-domain Task Force Report”, en International Research on Permanent Authentic Records in Electronic Systems (InterPARES) 2: Experiential, Interactive and Dynamic Records, Luciana Duranti y Randy Preston (eds.), Padova, Italia: Associazione Nazionale Archivistica Italiana, 2008. Disponible en: http://www.interpares.org/dis play_file.cfm?doc=ip2_book_part_5_modeling_task_force.pdf

Free On-Line Dictionary of Computing (FOLDOC). Disponible en: http://foldoc.org

InterPARES-The International Research on Permanent Authentic Records in Electronic Systems, "Chain of Preservation Model", en InterPARES 2, 2002. Disponible en: http://www.interpares. org/ip2/ip2_models.cfm\#

—_, "Requirements for Assessing and Maintaining the Authenticity of Electronic Records". InterPARES Authenticity Task Force. Appendix 2 de The Long Term Preservation of Authentic Electronic Records, 2002. Disponible en: http://www.interpa res.org/book/interpares_book_k_app02.pdf

- , "Interpares Template for Analysis of Electronic Records", InterPARES Authenticity Task Force Appendix 1 de The Long Term Preservation of Authentic Electronic Records, 2002. Disponible en: http://www.interpares.org/book/interpares_ book_k_app01.pdf

Society of American Archivists, A Glossary of Archival E Records Terminology. Disponible en: http://www2.archivists. org/glossary 
OTROS DICCIONARIOS DE ARCHIVÍSTICA EN ESPAÑOL DE RECIENTE EDICIÓN

Cruz Mundet, José Ramón, Diccionario de Archivística, Madrid:

Alianza Editorial, 2011, 363 pp. ISBN: 978-84-206-5285-6.

Heredia, Antonia, Lenguaje y vocabulario archivísticos: algo más que un diccionario, Sevilla: Consejería de Cultura, $221 \mathrm{pp}$. ISBN: 978-84-9959-038-7. 
Anexo

ONTOLOGÍAS

\section{ONTOLOGÍA A. Concepto de Documento de Archivo Digital (Digital Record)}

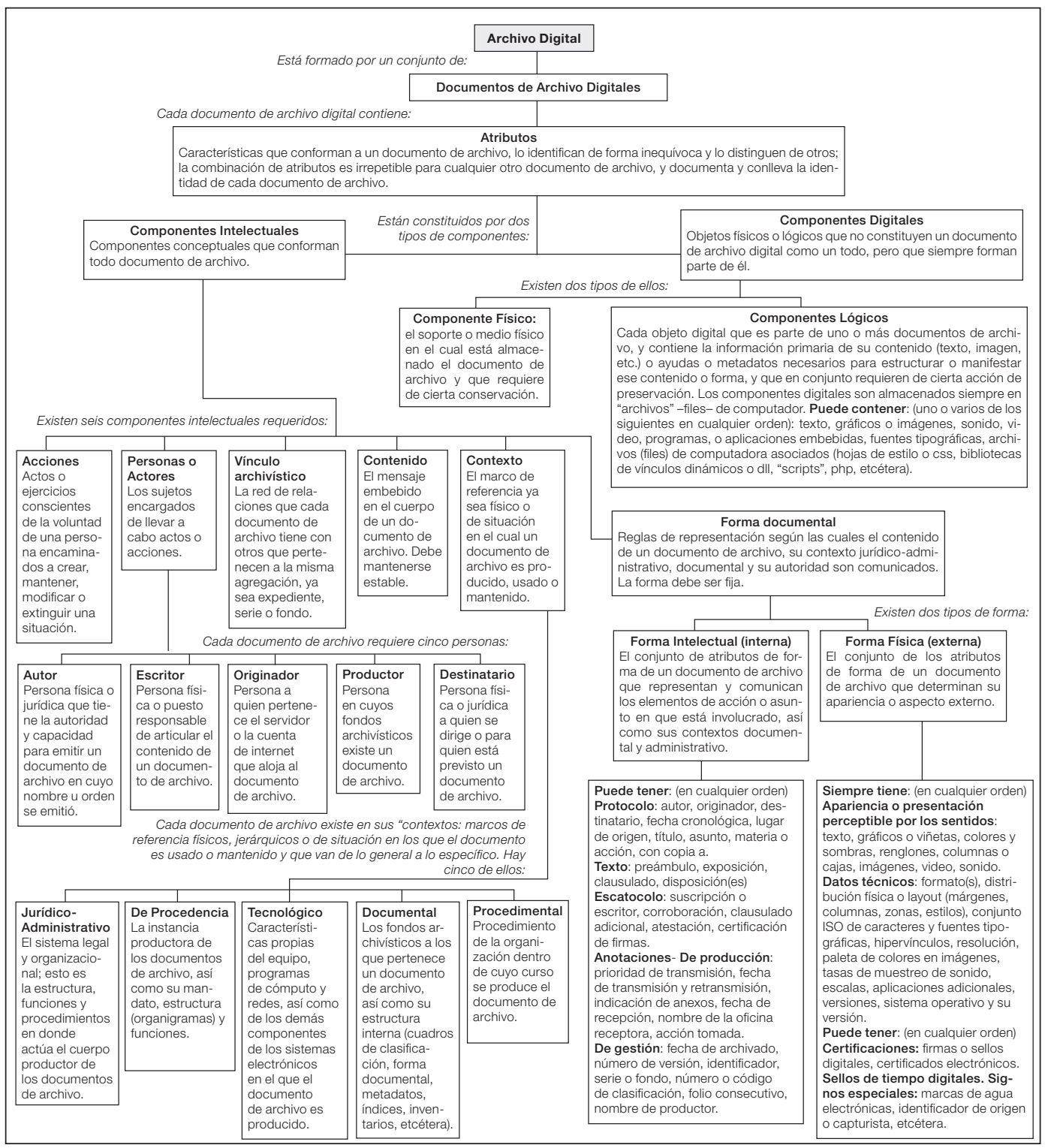




\section{Ontologías}

\section{ONTOLOGÍA B. Concepto de Estatus de Transmisión de un Documento de Archivo}

El grado de autoridad de un documento depende de su:

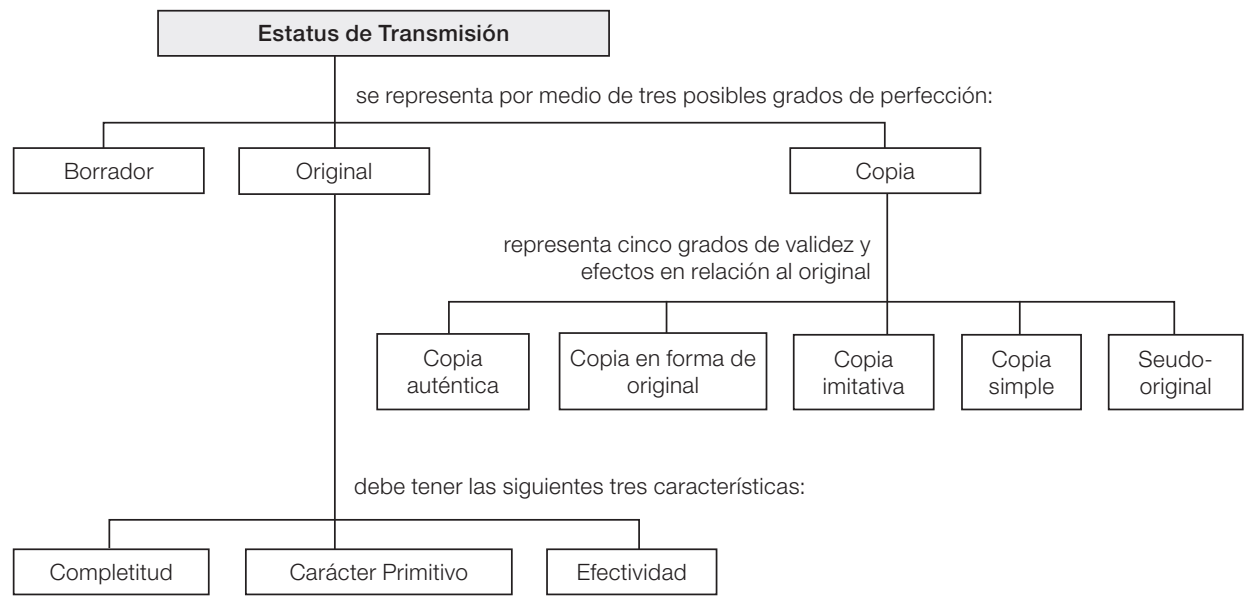

- Borrador: documento de archivo elaborado para corrección.

- Carácter primitivo: la cualidad de ser primero, original, no derivado de otra cosa.

- Completitud: característica de un documento de archivo que se refiere a la presencia dentro del mismo de todos los elementos requeridos por el creador y su sistema jurídico para ser capaz de generar consecuencias.

- Copia: el duplicado de un objeto, resultado de un proceso de duplicación. También se le denomina "duplicado".

- Copia auténtica o "copia certificada": la elaborada por persona autorizada para llevar a cabo tal función, y por tanto con validez legal.

- Copia en forma de original: una copia idéntica al original y que tiene sus mismos efectos, pero generada posteriormente.

- Copia imitativa: una copia que reproduce el contenido y forma de un documento de archivo, pero de manera tal que siempre es posible distinguir el original de la copia.

- Copia simple: aquella copia que simplemente reproduce el contenido de un documento de archivo.

- Original: la primer copia o arquetipo de un documento de archivo, de la cual otros instrumentos son transcritos, copiados o iniciados.

- Efectividad: característica que tiene un documento de archivo al existir dentro del mismo todos aquellos elementos que han sido requeridos por el creador y el sistema jurídico para que el documento llegue a las consecuencias o produzca los efectos para los que fue creado originalmente.

- Estatus de transmisión: grado de perfección en el que se encuentra un documento de archivo; esto es, borrador, original o copia.

- Seudooriginal: una copia de documento de archivo en la cual el fabricante de esa copia trata de imitar al original hasta el último detalle con el fin de hacer pasar la copia como original. 


\section{Ontologías}

\section{ONTOLOGÍA C. Confianza de un documento de archivo (trustworthiness)}

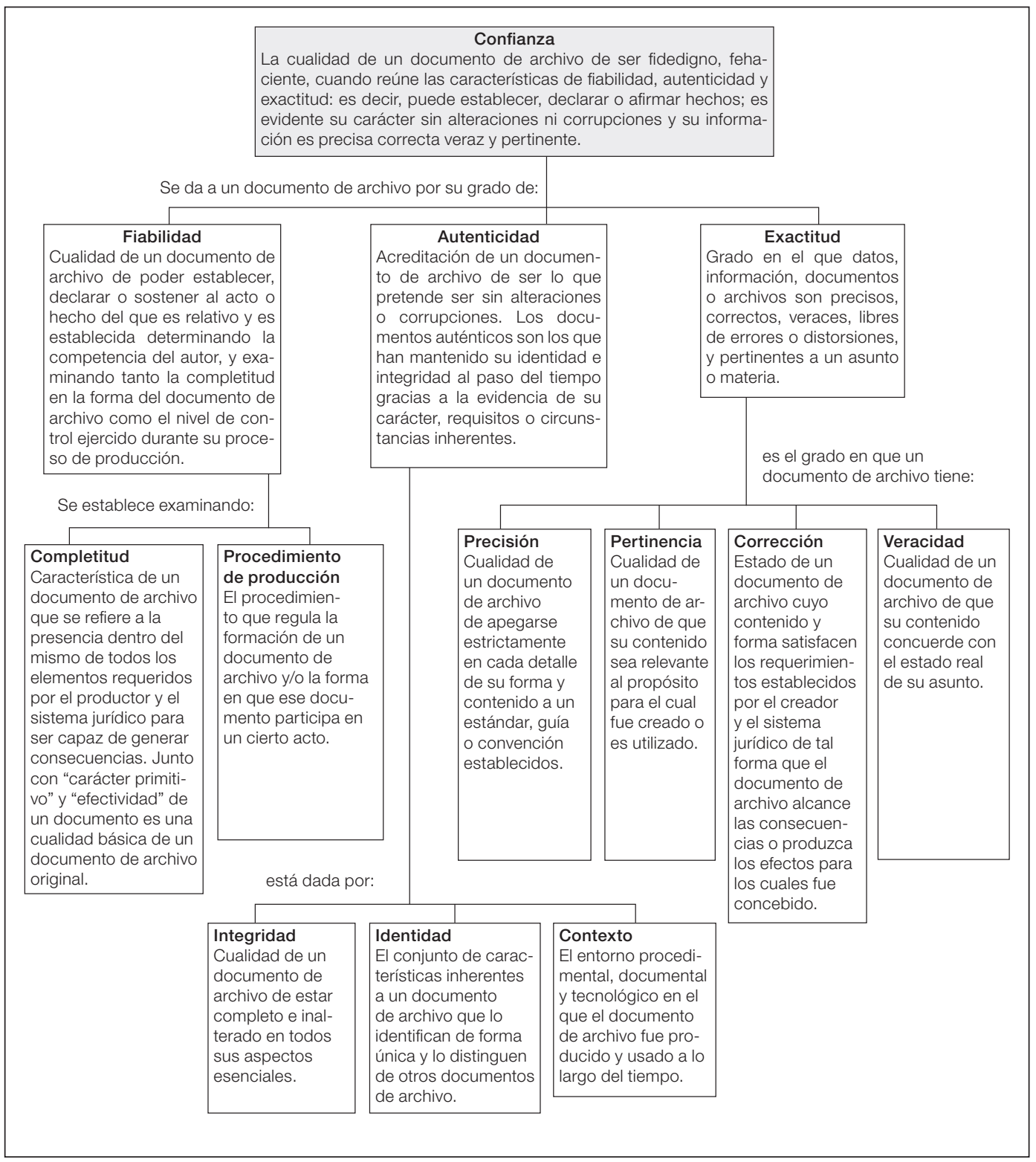


Glosario de Preservación Archivistica Digital Versión 4.0. La edición consta de 100 ejemplares. Coordinación editorial: Carlos Ceballos Sosa. Revisión y evaluación editorial: Aurea Gabriela Mondragón Pérez. Revisión especializada, lectura de pruebas y formación editorial: Jacobo Iván Martínez Vitela. Instituto de Investigaciones Bibliotecológicas y de la Información/UNAM. Fue impreso en papel cultural de $90 \mathrm{~g}$ en los talleres de Arte Gráfico y Sonoro, Retorno de Amores No. 14-102, Col. del Valle, México D.F. Se terminó de imprimir en el mes de septiembre de 2014. 